\title{
CHINEESCHE OFFICIEREN TE BATAVIA ONDER DE COMPAGNIE.
}

\author{
GEGEVENS, VERZAMELD DOOR
}

B. HOETINK.

Welke. Chineezen ten tijde van de Compagnie Hoofden hunner natie te Batavia waren, wordt nergens met juistheid vermeld. In de "Chronologische Geschiedenis van Batavia, geschreven door een Chinees» en vertaald door W. H. Medhurst) ${ }^{1}$ worden wel is waar ook de Kapiteins der Chineezen genoemd, maar de opgaaf is onvolledig, de namen der titularissen komen niet altijd overeen met de in authentieke stukken voorkomende en de jaren waarin zij gezegd worden in functie te zijn geweest, zijn in bijna alle gevallen onjuist.

Het is mij de moeite waard voorgekomen nauwkeurige lijsten samen te stellen van de Chineezen die in de $17^{\mathrm{e}}$ en $18^{\mathrm{e}}$ eeuw officier hunner natie te Batavia zijn geweest. Voor dat doel zijn de Resoluties van Gouverneur-Generaal en Raden opgespoord waarbij de benoemingen hebben plaats gehad en welke in het Algemeen Rijksarchief, in afschrift, aanwezig zijn over de jaren 1619-1793; voor latere jaren moesten de origineele Resoluties in het Landsarchief te Weltevreden worden nagegaan.

In die benoemingsbesluiten worden de namen van de aangestelde Chineezen (blijkbaar allen Hok-Kian- of zoogenaamde Emoy-Chineezen) gegeven in eene transcriptie van die namen zooals Europeesche ooren die hoorden; de ware - d. w. z. de in Chineesche karakters geschreven - naam, is tot nog toe slechts bij uitzondering met zekerheid bekend uit een grafschrift, uit een opschrift in een tempel of uit eene onderteekening van eene notarieele acte; de in onze lijsten gegeven Chineesche namen zijn, op die weinige uitzonderingen na, overgenomen van eene oorkonde van 2 November 1791 in het gebouw van den Chineeschen Raad te Batavia.

1 Tijdschrift v. Ned.-Indië, 3• Jaarg., 2॰ deel (1840). Dl. 78 . 
De datum van benoeming volgens de Chineesche tijdrekening, zal kannen dienen ter vergelijking met en verbetering van bekende opschriften en oorkonden.

Alle overige aangetroffen archiefstukken welke op de aanstelling van Chineesche officieren te Batavia betrekking hebben, voornamelijk hunne Commissies of acten van aanstelling en de relazen van hunne publieke voorstelling, zijn eveneens weergegeven. Volledigheid viel hier niet te bereiken, ${ }^{1}$ maar het gevondene volstaat om een inzicht te krijgen in hetgeen de verwisseling van een Hoofd, vooral als het een Kapitein gold, voor de Chineesche burgerij beteekende.

De Compagnie heeft het blijkbaar niet noodig geacht eene Instructie voor de Kapiteins vast te stellen. Hun gezag ontleenden dezen aan de hun door den Gouverneur-Generaal uitgereikte Commissie en berustte overigens op de usance. Eerst in 1754 heeft de Regeering aanleiding gevonden zich omtrent de bevoegdheden van de Chineesche officieren te uiten; tot eene omschrijving van hetgeen zij doen mochten en laten moesten, is het echter ook toen niet gekomen (zie Bijlage 1).

Van de benoeming van een Kapitein werd op plechtige wijze aan de Chineesche gemeente kond gedaan door zijne publieke voorstelling. De hem verleende Commissie werd op een daarvoor door de Regeering vastgestelden dag in optocht afgehaald en nadat de Gouverneur-Generaal dit document aan den benoemde had ter hand gesteld, werd het in tegenwoordigheid van daartoe gecommitteerde overheidspersonen in het Nederlandsch en in het Chineesch in het openbaar voorgelezen. Van zulk eene feestelijke installatie, welke den nieuwen titularis soms veel geld zal hebben gekost (zie b.v. $\mathrm{XV}^{\mathrm{b}}$ en $\mathrm{XVI}^{\mathrm{b}}$ ), werd in het ${ }^{\mathrm{N}}$ DaghRegister van het Casteel» aanteekening gehouden.

De bewaard gebleven Dagh-Registers van de jaren nà $1681^{2}$ maken deel uit van het Landsarchief te Weltevreden, en zijn nog niet in druk verschenen, zoodat hetgeen daarin staat aangeteekend omtrent de publieke voorstelling van Kapiteins - be-

1 Met erkentelijkheid gedenk ik de medewerking van Dr. J. de Hullu, Archivaris bij het Alg. Rijksarchief te 's-Gravenhage, en vooral die van Dr. F. de Haan, Landsarchivaris te Weltevreden.

2 Welke dit zijn, staat vermeld in het door Mr. J. A. van der Chijs in 1887 uitgegeven Dagh-Register 1640-1641, Voorwoord IV-V. 
houdens een paar belangrijke uitzonderingen - thans niet kon worden medegedeeld.

In de lijst van Kapiteins is twee malen eene gaping.

Toen in 1666 Kapitein Siqua kwam te overlijden, is hem niet dadelijk een opvolger gegeven ${ }^{1}$; tot 1678 is « het Capitainschap .... soo lange ten principalen bij deszelfs weduwe waergenomen , welke weduwe - volgens de "Chronologische Geschiedenis van Batavia, - eene Balische was. ${ }^{2}$

Kapitein Ni Hoekong, wiens gedrag bij het uitbreken van "de Chineesche Revolte" in 1740 , verdacht voorkwam, werd in hechtenis gesteld en naar Amboina verbannen. ${ }^{3}$ De toenmalige Luitenants verdwenen eveneens van het tooneel, met het gevolg dat aan het einde van October 1740 de Regeering voor de moeilijkheid stond dat te Batavia geen Chineesche Hoofden waren. Ook toen is in het gemis van Hoofden ten deele op eene eigenaardige wijze voorzien. Nadat de Kapitein te Cheribon en een koopman te Semarang te vergeefs waren aangezocht om te Batavia op te treden als introducteurs van hunne landgenooten die uit China en van de «buitenplaatsen» werden verwacht, werd een Europeaan, die tochten naar China had gedaan en daarom werd geacht met Chineezen te kunnen omgaan, aangesteld tot "Gecommitteerde over de aankomende Chineesen». ${ }^{4}$

Eerst in 1743 werden opnieuw Chineesche Hoofden benoemd.

Naast of onder de Kapiteins stonden de Luitenants.

Voor het eerst werd tot de aanstelling van een Hoofd met dien titel overgegaan in 1678, toen de Regeering tot het inzicht was gekomen dat het wenschelijk was het gezag over de Chineezen te Batavia wederom op te dragen aan iemand hunner natie en daarom opnieuw een Kapitein benoemde, aan wien een Luitenant werd toegevoegd (zie $\mathrm{V}$ a). In 1685 werd een tweede Luitenant aangesteld en in 1705 werd het aantal tot drie uitgebreid. Na in 1725 op vijf te zijn gebracht maar in 1726 weer tot vier te zijn verminderd, werd in 1729 hun aantal vastgesteld op zes. Toen na de troebelen van 1740 wederom tot de aanstelling van een

1 Zie Bijlage 2 en $\mathrm{V}$ a.

'Tijdschrift v. Ned.-Indië, 3e Jaarg., 2॰ Deel (1840), bl. 20.

s Zie Bijdragen 1918, bl. 447 e. v.

+ Zie Bijlage $3 \mathrm{c}$. 
Kapitein werd besloten (1743), werden tegelijkertijd ook twee Luitenants benoemd; in 1745 werd hun antal vermeerderd tot drie, in 1748 tot vier en ten slotte in 1762 tot zes.

Hoe de verhouding was, hoe ver de ondergeschiktheid van de Luitenants aan den Kapitein ging, welke bevoegdheid een Luitenant bezat en wat zijn eigenlijke taak was - dienaangaande is geene regeling aangetroffen. Zoolang de Kapitein in de gunst stond bij den almachtigen Gouverneur-Generaal, zal het hem geen moeite hebben gekost gedaan te krijgen dat alleen hem welgevallige Luitenants werden benoemd. Wel is het voorgekomen dat de Luitenants zich bij de Regeering over hun Kapitein hebben beklaagd en er zelfs in slaagden diens afzetting te bewerken.

Een acte van aanstelling schijnt niet aan de Luitenants te zijn uitgereikt, waaruit kan worden opgemaakt dat eene delegatie van hare macht op de Luitenants niet in de bedoeling der Regeering heeft gelegen en uitsluitend is verleend aan den Kapitein, die alleen tot communicatie zijner mindere officieren in hunne wekelijksche vergadering verplicht was. Zooals de Regeering het in hare Resolutie van 8 Juli 1729 formuleerde, waren de Luitenants geroepen den Kapitein te "assisteeren in het beslissen en verevenen van geringe geschillen die dikwijls of dagelijks onder die van hare natie occurreren en ter decisie van gemelte officieren volgens een al-oud gebruik werden overgelaten».

Aangenomen mag worden dat de "authorisatie in die bediening , de publieke voorstelling van een nieuwbenoemden Luitenant ${ }^{1}$ - zij het met geringer praal dan die van een Kapitein - regel is geweest en dat daarvan in het Bataviasche Dagregister aanteekening zal zijn gehouden.

Toen in 1678 - naar het heet op verzoek van de Chineesche gemeente - tot de aanstelling van "mindere hooftofficieren" werd overgegaan, werden behalve een Luitenant, ook een Vaandrig en iets later zelfs een Sergeant benoemd. Deze nieuwigheid heeft evenwel een kort bestaan gehad en dat Chineezen aan den jaarlijkschen optrek of eenig ander militair vertoon hebben deelgenomen, is ons niet gebleken.

De voor het meerendeel aan de Resoluties van GouverneurGeneraal en Raden ontleende personalia, treffen niet door

1 Vgl. Res. 16 Jan. 1682 (zie bij Luitenants, sub 3 b). 
belangrijkheid. Het napluizen van de omvangrijke reeks dezer bescheiden leverde zoo geringe uitkomsten op dat er van is afgezien dien arbeid tot het einde toe voort te zetten.

Wie zich de moeite zal willen geven om bijzonderheden op te sporen aangaande Chineesche ingezetenen van Batavia uit vroegere tijden, zal stellig niet vruchteloos zoeken in de uitgebreide verzameling notariëele stukken in het Landsarchief te Weltevreden. Ook mag worden verwacht dat begraafplaatsen, tempels, de archieven van den Chineeschen Raad, van het College van Heemraden, van het College van Schepenen en van den Raad van Justitie (het archief van het College van Boedelmeesteren is in 1811 door brand vernield) waardevolle gegevens zullen kunnen verschaffen. Al die Indische mijnen te ontginnen zal de taak kunnen worden van eene andere "Tiong Hoa Hoei, , van eene Vereeniging van Indische Chineezen die belangstellen in het verleden, in leven en bedrijf van hunne voorzaten.

's-Gravenhage, 1921. 


\section{Chineesch-Nederlandsche Jaartafel.}

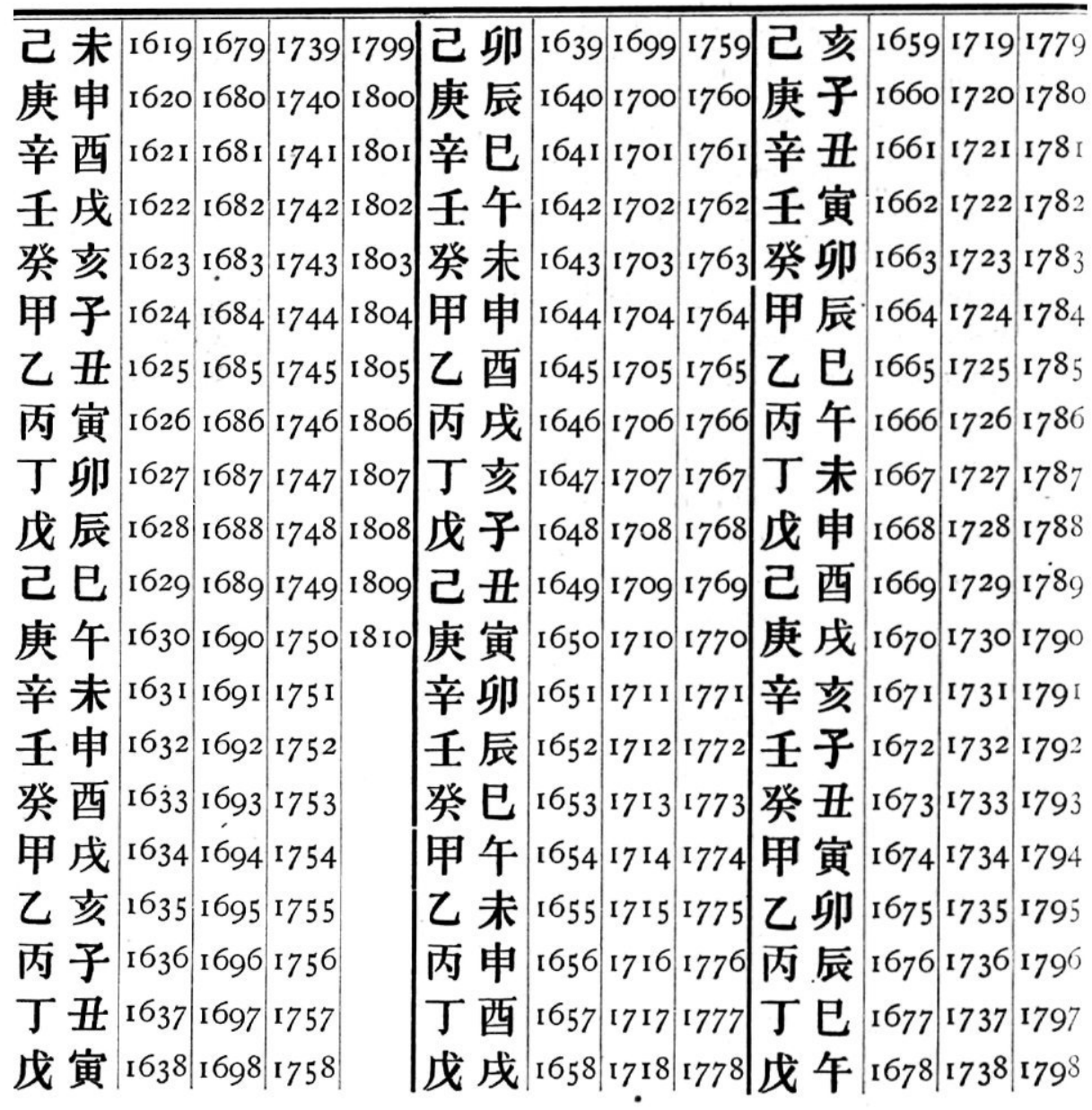

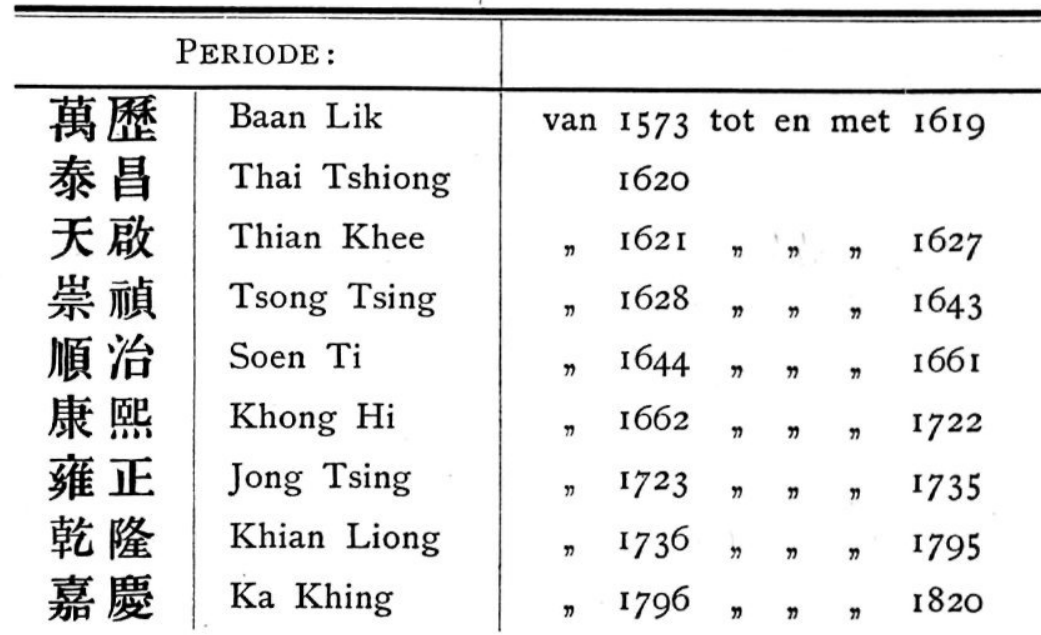


KAPITEINS

(1619-1809) 


\begin{tabular}{|c|c|c|c|c|c|c|c|c|c|c|}
\hline \multirow{3}{*}{ t } & \multirow{3}{*}{$\begin{array}{c}\text { Naam } \\
\text { in de resolutie } \\
\text { van benoeming }\end{array}$} & \multirow{3}{*}{$\begin{array}{l}\text { Chineesche } \\
\text { naam }\end{array}$} & \multicolumn{7}{|c|}{ Dat van benoeming } & \multirow{3}{*}{ Gouverneur-Generaal } \\
\hline & & & \multirow{2}{*}{ Europeesche } & \multirow{2}{*}{\multicolumn{3}{|c|}{ nyclusja }} & \multirow{3}{*}{$\begin{array}{l}\text { Jaar } \\
47\end{array}$} & \multirow{3}{*}{$\begin{array}{c}\text { Maand } \\
9\end{array}$} & \multirow{3}{*}{$\frac{\text { Dag }}{5^{2}}$} & \\
\hline & & & & & & & & & & \\
\hline I. & Bencon & 蘇鳴崗 ${ }^{1}$ & II October I619 & 己末 & 萬柲 & Baan Lik & & & & Coen \\
\hline II. & Limlacco & 林六哥 & 21 Juli ${ }_{1}{ }_{3} 6$ & 丙子 & 崇形 & Tsong Tsing & 9 & 6 & 23 & van Diemen \\
\hline III. & Bingam & 潘明䉷 & 4 Maart I645 & 乙元 & 順治 & Soen $\mathrm{Ti}$ & 2 & 2 & 7 & 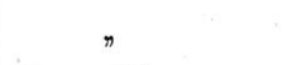 \\
\hline IV. & Siqua & 顔二官 & Io April I663 & 癸外 & 康熙 & Khong $\mathrm{Hi}$ & 2 & 3 & 3 & Maetsuijker \\
\hline V. & Tsoa Wanjock & 蔡煥玉 & I4 Juni 1678 & 戊午 & $n$ & $\pi$ & I7 & 4 & 26 & van Goens \\
\hline VI. & Queeconko & 郭郡 哥 & 3 Augustus 1685 & 乙丑 & , & $n$ & 24 & 7 & 4 & Camphuijs \\
\hline VII. & Limkeenqua & 林敬官 & IO Juni 1695 & 乙亥 & , & n & 34 & 4 & 29 & van Outhoorn \\
\hline VIII. & Tambocco & 陳穆哥 & II April I707 & 丁亥 & n & n & 46 & 3 & 9 & van Hoorn \\
\hline IX. & Quebauqua & 郭暃官 & 3 Maart I7.19 & 已亥 & $n$ & $n$ & 58 & I & $\mathrm{I}_{3}$ & Zwaardecroon \\
\hline $\mathrm{X}$. & Que Tjoenqua & 郭春官 & 6 Januari 1733 & 壬子 & 雍正 & Jong Tsing & IO & II & $2 \mathrm{I}$ & van Cloon \\
\hline XI. & Nihoekong & 連褔 ${ }^{3}$ 公 & I I September 1736 & 丙层 & 乾隆 & Khian Liong & I & 8 & 7 & Patras \\
\hline XII. & Lim Beengko & 林明哥 & 28 Juni 1743 & 癸亥 & $n$ & " & 8 & 5 & 7 & van Imhoff \\
\hline XIII. & Oeij Tsomko & 黃箴哥 & 21 April I747 & 丁外 & $n$ & $n$ & I 2 & 3 & 12 & $n$ \\
\hline XIV. & Oeij Tsjilauw & 黃鈰老 & 7 Juli 1750 & 庚午 & n & $n$ & 15 & 6 & 4 & n \\
\hline $\mathrm{XV}$ & Lim Tjipko & 林緝哥 & 27 Augustus I756 & 丙子 & n & $n$ & $2 \mathrm{I}$ & 8 & 2 & Mossel \\
\hline XVI. & Ting Ingko & 唐恩哥 & 3I Januari I 775 & 乙 未 & n & $n$ & 40 & I & I & van der Parra \\
\hline XVII. & Oeij Hingko & 黃恒哥 & I9 December I775 & 乙 未 & $n$ & , & 40 & IO & 27 & $\eta$ \\
\hline XVIII. & Swa Toenko & 蔡敦哥 & 26 November 1784 & 甲层 & $n$ & $n$ & 49 & IO & 14 & Alting \\
\hline XIX. & Ong Tjoeseeng & 王珠生 & 8 Juni 1790 & 庚成 & $n$ & " & 55 & 4 & 26 & $n$ \\
\hline $\mathrm{XX}$ & Oeij Biankong & 黃綿公 & II October I79I & 辛亥 百 & $n$ & n & 56 & 9 & 14 & $n$ \\
\hline XXI. & Gouw Tjangsie & 吳纘緒 & 27 December 1800 & 庚申 & 嘉慶 & Ka Khing & 5 & II & I2 & van Overstraten \\
\hline XXII. & Tan Peengko & 陳 炳哥 & 26 October 1809 & 已民 & $n$ & $\eta$ & I4 & 9 & I 8 & Daendels \\
\hline
\end{tabular}

1 Zoo onderteekende hij en zoo staat op zijn grafsteen.

2 Zie Concordance des chronologies néoméniques chinoise et européenne par le Rérv. P. Hoang. Chang-Hai rgro (Variétés sinologiques No 29).

3 In dezen vorm (met het $145^{\mathrm{e}}$ klassenhoofd) in zijne onderteekening van eene notarieele acte. Het karakter is aangetroffen in Medhurst's Chinese and English Dictionary, Batavia, 1843, II, I002. via free access 


\section{Bencon.}

\section{Res. Vrijdag den 11 October 1619.}

Alsoo hier tegenwoordich omtrent 400 Chinesen onder onse bescherminge sijn woonende ende nodich is, dat daerover een bequaem persoon uijt deselvige tot overhooft gestelt worde omme soo veel mogelijck goede orde ende policie onder haer te doen onderhouden, waertoe bij de voornaemste Chijnesen uijt alle haere naem voorgedragen is eenen genaempt Bencon, soo is goetgevonden den voorsz. Bencon bij provisie als overhooft over de voorsz. Chinesen te authoriseeren, met last omme alle civile saecken aff te doen ende andere swaere saecken aen ons te renvoijeeren.

So Bing Kong vertrok 3 Juli 1636 naar China doch bleef op Formosa en kwam 14 Maart 1639 te Batavia terug (Res. 20 April 1639) waar hij 8 April 1614 overleed en waar zijn graf nog aanwezig is.

Zie over hem: So Bing Kong, het eerste Hoofd der Chineezen te Batavia (1619-1636), in Bijdragen Kon. Instituut, deel 73 (1917) bl. 344 e. v., van welk opstel eene vertaling in het Maleisch verscheen onder den titel: „Hikajat Kapitein Souw Beng Kong”. Batavia, 1918.

Eene "Nalezing" van dit artikel is in bewerking.

\section{Limlacco.}

a. Res. 21 Juli 1636.

Alsoo door het vertreck van Bencongh (die met ons advoij op den $3^{\text {en }}$ deser $p^{r}$ het schip Bredamme over Taijouan naer Chijna is gevaeren) desselffs ampt als Capiteijn ende voorspraeck der Chijnesen in Battavia residerende, tot op heden vaccandt gebleven is, ende het hoognoodich sij 't gemelte Capiteijn's ampt door een goet, trouw ende ervaeren persoon (uijt de alhier wonende Chinesen te verkiesen) weder wort becleeth, Ten welcken eijnde ende op onse voorige ordre, door de Chineese Burgerije int generael voorgedraegen sijn ende in consideratie comen, de persoonen van Limlacco ende Jancongh, soo ist dat op heden de requisatoire verthooningen dienaengaende aen ons overgelevert 
g'examineert ende de stemmen ter wedersijden gecoligeert sijnde, bevonden wert $\mathrm{Lim}$ Lacco bij pluraliteijt van stemmen voor Jancongh geprefereert ende bij ons voorder in consideratie genomen wesende tgestaedich ende langhdurich verblijven van geseijden Lacco met sijn familie in Batt ${ }^{\mathrm{a}}$ sonder te bougeren, gelijck Jancongh niet gedaen heeft, die oock noch gesint blijft andermael naer China te keeren, item in achtinge genomen sijnde de goede devoiren bij hem Lacco $\mathrm{A}^{\circ} 1628$ ende 29 aengewent tot beslechtinge van den geduirigen oorloge tusschen de Nederlantse Comp ${ }^{\text {ie }}$ ende die van Bantam, ende dat sich nu andermael desen jare ettelijcke reijsen gedienstich heeft laeten gebruijcken tot affhandelinge van de questije ende oorloge tusschen ons ende Bantam $A^{\circ} 1633$ weder ontstaen, sijnde de saecke door sijn toedoen soo verre gebracht dat in termen van goet succes tot beslechtinge des oorloghs staen, deswegen goetgevonden ende gearresteert is omme dese ende andere redenen meer den persoon van Limlacco met het ampt als capiteijn, overhooft ende voorspraeck der geseijde Chinesen alhier te benefitieren omme tselve ampt te becleeden met soodaenigen macht ende gelijcke authoriteijt als Bencon gehadt heeft waertoe hem oock een behoorlijcke commissie sal worden gedepecheert.

b. Res. $28 \mathrm{Ju} 1 \mathrm{i} 1636$.

Anthonio van Diemen Gouverneur-Generael etc ${ }^{a}$.

Alsoo door het vertreck van capit $^{\mathrm{n}}$ Bencon, gewesen overste ende voorspraeck der resideerende Chijnesen alhier, over Taijouan naer Chijna sijn vaderlant, desselffs plaetse nu vacceert ende hoognodich is dat wederom met een bequaem ende wel gereputeert persoon becleet werde, gelijck ons tot dien eijnde bij de voornaempste Chinesen uijt haer aller name voorgedragen ende gerecommandeert is den persoon van Limlacco, welcke sich onder deselve als de Comp ${ }^{\text {ie }}$ door verscheijden goede diensten aengenaem ende bemint heeft gemaeckt, Soo ist dat wij, ons als vooren van desselffs bequaemheijt ende capaciteijt gecontenteert houdende, hem Limlacco gestelt ende geauthoriseert hebben gelijck wij hem stellen ende authoriseeren bij desen als capit ${ }^{n}$, overhooft ende voorspraeck der resideerende Chijnesen alhier met soodaenige macht ende authoriteijt als sijnen predecesseur Bencon heeft gehadt, naementlijck om alle cleene voorvallende saecken onder gemelte Chijnese burgerije uijt onsen naeme aff te doen 
ende de groote ofte andere debieuse aen ons voor te draegen ende renvoijeeren mitsgaeders voorders te doen wat een goet vroom capit $^{\mathrm{n}}$, overhoofd ende voorspraeck toestaet ende betaemt.

Derhalven ordonneeren ende beveelen aen alle Chijnesen hier resideerende ende die naermaels souden mogen comen, den voorschreven Limlacco als haeren capiteijn, overhooft ende voorspraek t' erkennen, respecteeren ende gehoorsaemen, gelijck wij oock aen alle dienaers van de Compagnie ende onse Nederlantse ingeseetene, onder onse gehoorsaemheijt sorteerende, bij desen beveelen denselven in sijn offitie alle behoorlijcke eere, respect, hulpe ende faveur te betonen alsoo wij tselve ten dienste van de Generaele Compagnie ende gerieff der gemelte Chijnese burgerije soodaenich vinden te behooren.

Actum int Casteel Battavia ten dage ende jaere als vooren. Ende was onderteeckent: Antonio van Diemen, Philips Lucasz ende Aertus Gijsels.

c. Dagh-Register 1636.

28 Julij. Tegen den middach wort door de heeren Philips Lukas ende Aert ${ }^{\mathrm{s}}$ Gijsels, Raden van India, den ontfvargergeneraal Cornelis van Maseijck ende den president Joan Ottens versterckt met d'eerwaardige magistraat, voor het stadhuijs deser stede naer voorgaende clocken geslach ende volckvergaderingh met goed fatsoen geauthoriseert den persoon van Limlacco chinees als capiteijn ende voorspraeck der residerende ende overcomende Chinesen in Batavia, met soodanigen macht als zijnen predecesseur Bencon (die op $3^{\text {en }}$ dezer over Taijouan naar China gekeert is) gehadt, ende volgens de commissie welke hem den Gouverneur Generael tot dien eijnde verleent heeft, die ook int openbaar den volcke voorgelesen ende bekent gemaeckt sij.

In de Generale Missive van 10 Dec. 1616 (Coen, uitg. Colenbrander I, 244), wordt van dezen lateren Kapitein gesproken als "naasten raad van den Pangeran te Bantam". In de Generale Missive van 26 Juli 1618 (Coen, I, 360) heet hij "een geschoren d.w. z. een tot den Islam overgegane Chinees". Zie ook Coen, I, 349-350. -- In de Generale Missive van 20 Juni 1623 (Coen, I, 776) zegt G. G. Coen:

"Omtrent 170 personen waren... (cort voor ons vertreck) overgecomen [van Bantam naar Batavia], daeronder eenen Lim Lacco met vrouw; kinderen ende gevolch, die eertijts sterck met de Compagnie 'gehandelt heeft ende ten respecte van goede dienst de Compagnie gedaen ende verscheyden consideratien hebben hem met goede benefitie vereert." G. G. Coen vertrok van Batavia den $2^{\text {n }}$ Febr. 1623. 
Zulk een benefitie wordt vermeld in het Boek van Leningen (Overgekomen brieven 1623. Derde Boek Z. in Koloniaal Archief). ${ }_{n}$ Adij 17 Jan. [anno 1623] heeft d'Ed. heer Generael vergundt aan Lim Lacco alias schoenmaker van Bantam exemptie van maentlijck hooftgelt voor thien pcrsoonen in sijnen dienst wesende ende dat voor vier jaren."

Eene andere werd hem vereerd bij de volgende resolutie:

Woensdach adi 25 Januario 1623.

Lacco, alias Schoenmaecker, Chinees coopman, dese voorleden dagen met sijn huijsvrouwe ende huijsgesin, in groot perijckel sijns lijffs, heel berooijt van Bantham overgecoomen ende als een burger alhier nedergeseten sijnde, ernstelijck versocht hebbende, met eenich gelt, partije oleeden als andere goederen te borghe vertrouwt ende gesecoureert te mogen werden, omme sijnen vervallen staet met onse hulpe wederom sooveel mogelijk te restaureren, ende de negotie alhier te helpen accresseeren, met welcke hoope ende intentie hij, al 't sijne tot Bantham verlatende, herwaerts gecomen was, waerop, naer rijpe deliberatie, consideratien van sijne voorige gedaene diensten tot Bantam, alsmeede dat men voor veele wichtige redenen geentsints geraden gevonden heeft yets meer uijt te borgen ende wederom in schulden te treden, goetgevonden ende geresolveert is, den voorsz. Lacco boven de 400 realen van achten, hem voor desen in contant geschoncken, noch te vereeren met 600 realen van achten in cleeden, hem aenseggende sich daermede soecke te behelpen, ende yets ter hant te nemen om hem met sijn huijsgesin te sustenteeren, alsoo een vaste genomen ordre is, niemant roortaen meer te borgen.

(Coen, III, 964). Zie ook Res. 28 Jan. 1623 (Coen, III, 956).

In 1626 behoorde hij tot de "gequalificeerde cooplieden (So Bing Kong, 387) en alzoo tot de voornaamste Chineesche ingezetenen van Batavia.

Over zijne bemoeiingen ter bevordering van den vrede van de Compagnie met Bantam, zie de Bataviasche Dagregisters van 1636, 1637 en 1638; De Jonge, Opkomst V; Begin ende Voortgangh II (Reis Hagenaer), bl. 104 en 105; Kroniek Hist. Gen. IX (1853) bl. 277 en 301, zoomede den volgenden brief door G. G. Anthonio van Diemen aan hem gerieht (Koloniaal Arehief $\mathrm{N}^{\circ} 764$ ):

Bantam. Aen Capiteijn Lacco.

Pr Vlieger.

Capiteijn Lacco. Wij hebben uijt uwen brieff begrepen dat den Pangoran van-Bantam tot de vrede met de Nederlanders genegen is. Lacco weet ende kent ons herte. Wij trachten na peijs ende eenicheijt dat blijckt, wandt de Nederlanders hebben die van Bantam geen onrecht gedaen.

Maar soo des Pangorans herte oprecht is, waarom laet hij de moordenaeren ongestraft, ende de schade van onsen Burger die meer als die duijsent realen bedraecht, onvergoet.

$\mathrm{Nu}$ omme onse genegentheijt tot vreede voor alle de werelt te doen blijcken ende dat Lacco eere van zijne besoignes erlange, sullen wij de Justitie ende Wraecke Godt ende den Pangoran bevoolen laeten, ende uijt de Mássoije onsen Burger zijn schade vergoeden, daer veel aen te cort comen sal, ende hiermede ist dan vreede (soo het den Pangoran geliefft) getroffen. Wij sullen voleq tot Bantam woonen ende handelen laeten; in twee daegen vertreckt den Generael naer Amboijna; met lieff 
weder gecomen wesende, zall den Pangoran ende Grooten tot Bantam begroeten.

Bij aldien den Pangoran hier toe verstaet, zal Laceo daervan rapport doen aen den Presid' Lucas Capt ${ }^{\mathrm{n}}$ Patanij, die van alles last heeft gelijck off den Generael selver tot Bantam was.

Godt bewaere U Capt ${ }^{n}$ Lacco ende groet den Pangoran met de grooten tot Bantam.

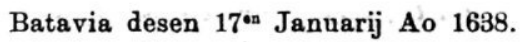

Anthonio van Diemen.

Dat hij met zijn voorganger op goeden voet heeft gestaan, kan worden opgemaakt uit diens aanbeveling van zijn zoon Boycko voor tolk op Formosa (Sㅡ Bing Kong, 399). Deze Boycko is waarschijnlijk "de soon van Cap ${ }^{t}$ Lacco" die deel nam aan de voordracht van een opvolger van zijn vader (III c.).

Limlacco overleed omstreeks Februari 1645 (Zie IIIa).

\section{Bingam.}

a. Res. 8 Februari 1645.

Onlangs alhier overleden wesende den ouden Limlacco, Capiteijn ende voorspraek van de ingeseten, als aen ende affvarende Chinesen alhier, waer door dat ampt nu compt te vaceren ende weder met een ander ervaren Chinees dient gesuppleert, daertoe ons ook rheede verschijden solicitanten, versterckt met het voorspreecken der Chinese gemeente voorcomen ende request hebben gepresenteert, Ende alsoo de Chinesen die hier jaerlijcx uijt China comen handelen daer mede eenighsins aen gelegen sijn, ende eerstdaegs weder te verschijnen staen, soo is goet gevonden met het begeven van dat ampt noch tot de comste der Chinese joncquen te supercederen om de naghoda's ende principale cooplieden desselffs alvoren te horen ende verstaen tot wat persoon 't sij dan Conjoc ofte Bingam (die bij ons daertoe in consideratie comen) sij meest inclineren om d'een ende d'ander hier in soo veel contentement te doen als ten besten van dese republieque sullen vinden te behoren.

\section{b. Res. 4 Maart 1645 .}

Volgens Resolutie van 8 Februarij passado tot noch toe in bedencken gebleven sijnde, op het nomineren ende stellen van een nieuwen capiteijn over de ingeseten, aen ende affvarende Chinesen alhier, ende onderentusschen oock uijt China verschenen 
wesende, de verwachte joncquen behalven de derde die noch achterblijft, welckers opperhooffden ende cooplieden ons eenige persoonen daer toe hebben voorgedragen ende tot Capiteijn versocht. Ingevolge dan aenmerckende het dagelijcs geloop ende menichvuldige versoecken die bij de Chinesen int generael soo wel cleijn als groot, door ende voor verscheijden persoonen werden gedaen, waren te rade geworden het eersame collegie van Schepenen te gelasten dat alle de voornaemste ende principaelste Chinesen deser stede tot omtrendt 12 intgetal voor haer souden doen citeren ende opt secretelijckste van haer een voor een trachten te verstaen, wien sij van de voorgedragene den bequaemsten achten, om ons na hare genegentheijt ten beste van dese republijcque ook een weijnich te mogen reguleren, den President [de] Vlamingh [van Outshoorn] heden weder rapport doende verthoont ons schriftelijck dat genoemde Collegie het gerecommandeerde getal niet min als op 24 persoonen hadde connen uijtvinden waer bij bevonden wert dat den Chineese coopman Bingam 12: Siqua ende Conjock elck 3, den doctor Isack (die Christen is) 2 ; ende de Zoon van den overledenen Capiteijn Limlacco mede twee stemmen heeft, soo ist dat wij dan nu op dese gelegentheijt ende de voorgedragen als toegestemde persoonen met aendacht lettende ende gansch genegen sijnde de Chinese gemeente soo veel contentemendt te geven, als eenighsints buijten prejuditie vande Comp ${ }^{\text {ie }}$ ende crenckingh onser authoriteijt can geschieden twelck dan meest op Bingam siet, hoe wel door verscheijde ter handtgenomen ende mislucte saecken aen de Comp ${ }^{\text {ie }}$ ende andere noch vrij wat ten achteren is ende Conjock dat Ampt mede wel bequaem, maer qualijck soo bemindt vinden, soo is verstaen ende geresolveert meergenoemden Bingam voor wiens t'achterheijt ende goede regeringh haer veele tot burgen stellen, volgens acte onder den Gouverneur Generael berustende, met het aengetoogen Capiteijns Ampt te benificieren dogh niet absoluijt, eenlijck bij provisie voor een jaer, om als dan na ondervindingh van sijn comportement gecontinueerd ofte wel (gelijck Schepenen) met het versetten van de wet deser stede verandert te werden, daer door vertrouwen denselven te beter tot ons devoir ende genoegen van de Chinese gemeente sullen connen houden. 
c. $(4 \mathrm{Maart} 1645){ }^{1}$

Aen mijn $\mathrm{h}^{\mathrm{r}}$ den Gouverneur Generael Anthonio van Diemen.

Ede Genereuse Heer

Mijn heer.

Achtervolgens $\mathrm{UEd}^{e}$ expres bevel, mij voor drie a vier dagen gegeven, hebbe op heeden de gequalificeerste Chineese Ingesetenen alhier voor ons citeren laten, ende d'selve UE. goede meijninge bekent gemaeckt maer is het getal vrij hooger geloopen als $\mathrm{UEd}^{e}$ ons wel hadt gerecommandeert, bijgecomen de number van twaelf a dertien persoonen soo $\mathrm{UEd}^{\mathbf{e}}$ woorden omtrent [waren] luijdende, niet uijtvinden conde, off soude daer onder geweest sijn soodanige aen welckers persoonen en gelegentheden andere van gelijcke conditien hun soude hebben gestooten off g'affronteert gehouden, 't welck ons dan, ende uijt sijn $\mathrm{Ed}^{\mathrm{e}}$ woorden niet anders hebben bemerckt of maer trachtende de Chineesse gemeijnte te behagen ende genoegen toe te brengen, tot 't overtreden van voorschr. getal doen resolveren heeft, dat versoecke UEd $\mathrm{U}^{\mathrm{e}}$ ons niet qualijck gelieft aff te nemen.

De geciteerden en gecompareerden nu sitplaetsen rontsom den raetcamer aengewesen, ende deselven voort tot hun genoegen bekent gemaect sijnde, d'ordre in desen te gebruijcken hadden voorgenomen, deeden hun soo aen mij als $\mathrm{S}^{\text {ren }}$ Coolsaet en Durens naest malcanderen sittende, ider aparte stillekens nommeert den persoon welcke tot hun Capiteijn de bequaemste oordeelden te sijn diens advijs dan tegens sijn name over (:alvorens alle ordentelijcke sijnde gestelt:) schrijven lieten, 't welck een ende ander, te weten 't eerste soodanich uijt gevonden te hebben ten eijnde niemant uijt vrese van haet schroomachtich wesen mochte sijn votum libre te geven ende .... o op dat de Chineesen naermaels niet te fingeren en mij naer te geven mochte comen, ick anders als hun seggen hadde aengeschreven daer eenige snoot genoech toe sijn, oock door misverstandt geen abuijs mocht worden begaen; de stemmen sijn gevallen soo $\mathrm{UEd}^{\mathrm{e}}$ hier vervolgens leest

namentlijck:

Siqua nomineerde . . . . . . . . Isaacq off Loccon

1 Landsarchief te Weltevreden. 


\begin{tabular}{|c|c|c|c|c|c|c|c|c|c|}
\hline Isaacq of Lo & occor & & . & . & . & . & . & & \\
\hline Binggam . & . & . & . & . & . & . & . & & de zoon van Lacco \\
\hline Conjock & 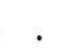 & . & . & . & . & . & . & . & de zoon van Lacco \\
\hline Sjunqua ) & & & des & . & . & . & & & Siqua \\
\hline Chiqua $f^{a}$ & anacr & noo & ${ }^{\text {des }}$ ! & . & . & . & . & . & Binggam \\
\hline Bappa Bingh & hsan & & . & . & . & . & . & . & Siqua \\
\hline Goyko . . & . & . & . & . & . & . & . & & Conjock \\
\hline Janquip . & . & . & . & . & . & . & & . & Binggam \\
\hline Jochy . & . & . & . & . & . & . & . & . & Isaacq off Loccon \\
\hline Notian . . & & & . & . & . & . & . & . & Binggam \\
\hline de soon van & n Ca & & & co. & . & - & . & . & Binggam \\
\hline Binthon. . & . & & . . & . & . & . & . & & Binggam \\
\hline Janghsan . & . & & . & . & . & . & 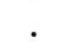 & & Siqua \\
\hline Maucko of $\mathrm{F}$ & Bauc & cko & . & . & . & . & . & . & Binggam \\
\hline Insou. . . & .. & . & . . & . & . & . & . & . & Binggam \\
\hline Lacqua, arra & acqb & oran & nder & & . & . & . & . & Binggam \\
\hline Pieco. . . & & & & & . & . & . & & Siqua \\
\hline Tonquit. & . & . & . & • & - & . & • & & Siqu \\
\hline Intco. . & . & & . & & . & . & . & . & Conjock \\
\hline Noco. . . & . & & . & & . & . . & . & & Binggam Jinjouw \\
\hline Jinjouw alias & as $\mathrm{Pa}$ & anja & ingh 1 & & chte & $r$ van & de & top ${ }^{t}$ & Binggam \\
\hline Thonghoy . & 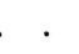 & & & & & & . & & Binggam \\
\hline Collacco . &. & & & & & & & & Conjock \\
\hline
\end{tabular}

de genomineerde sijn desen ende hebben stemmen als namentlijck

Stemmen

12 Binggam

6 Siqua

3 Conjock

2 Isaacq of Loccon

2 de soon van Cap $^{n}$ Lacco

Gedaen ter vergaderinge van Schepenen datum ut supra.

Dit ongedagteekende stuk is zonder een woord van toelichting geinsereerd in de Resoluties van Schepenen, nà die van 9 Januari 1645 en vóór die van einde Mei 1645. Uit den inhoud blijkt dat het is het rapport door den President van Schepenen de Vlamingh van Outshoorn den $4^{\text {en }}$ Maart 1645 ingediend aan G. G. van Diemen en aangehaald in de resolutie van dien datum waarbij Bingam tot Kapitein is benoemd (bl. 15).

Dl. 78. 
Zoowel in het rapport als in de resolutie, is de uitslag der stemming onjuist vermeld.

In 1636 heeft eene dergelijke stemming plaats gehad (zie bl. 11).

\section{d. Res. 6 Maart 1645 .}

Om den op eergisteren bij provisie voor een jaer vercooren Chinesen capiteijn Bingam morgen voor het stadthuijs deser stede na gewoonte behoorlijck t'authoriseren ende bekendt te maecken, werden bij desen goetgevonden te committeren den $\mathrm{E}$. directeur van der Lijn voormelt, den E. Simon van Alphen extraordinaris Raed van Indien, den ontfanger generael Sebaldt Wonderer mede voornoempt, Pieter Mestdach secretaris deser vergaderingh ende den provisionelen president van Schepenen Arnoldt de Vlamingh van Outshoorn met dat gantsche collegie, mitsgaders hier toe opgemelten Bingam te passeren de volgende acte ofte commissie, luijdende als te weten:

Anthonio van Diemen gouverneur-generael ende de Raden van India over den standt der Vereenichde Nederlanden in Orienten allen dengenen die desen sullen sien ofte hooren lesen saluijt doen te weten alsoo door het overlijden van Limlacco gewesen capiteijn, opperhooft ende voorspraeck der residerende Chinesen alhier dat ampt nu vaceert ende hooghnodigh is tselve weder met een bequaem, ervaren ende aengenaem persoon becleet werde, gelijck ons tot dien eijnde bij de voornaemste [bij] pluraliteijt van stemmen voorgedragen ende gerecommandeert sij den persoon van Bingam, welcke sich onder deselve als bij de Compagnie door verscheijde goede diensten ende ter handt genomen saecken ten besten van dese republijcque meest aengenaem ende bemindt heeft gemaect, Soo ist dat wij ons dan met desselffs bequaemheijt ende capaciteijt vernought houdende denselven volgens onse resolutie van 4 deser bij provisie voor den tijt van twaelff maenden gestelt ende g'authoriseert hebben gelijck hem stellen ende authoriseren bij desen als capiteijn, overhooft ende voorspraeck der residerende, aen- ende affvarende Chinesen alhier met sodanigen macht ende authoriteijt als sijnen genoemden predecesseur Limlacco heeft gehadt, namentlijc om alle clene voorvallende saecken onder de Chinese burgerije uijt onsen name aff te doen ende de groote off dubieuse aen ons voor te dragen off tot het eersame collegie van Schepenen deser stede te renvoijeren, mitsgaders voorts te doen wat een goedt vroom 
capiteijn, opperhooft ende voorspraecke toestaedt ende betaemdt. Ende dat als geseijt bij provisie voor een jaer om alsdan na ondervindingh gecontinueert ofte wel met het versetten van de wet verandert te werden. Ordonneren ende bevelen derhalven bij desen alle hier residerende, aen- ende affvarende Chinesen den voorschreven Bingam. als haren capiteijn, overhooft ende voorspraecke gedurent gemelten tijt t'erkennen, respecteren ende gehoorsamen, gelijck wij dan oock alle dienaers van de Compagnie ende Nederlantsche als andere ingesetenen onder onse gehoorsaemheijt zorterende, niemandt uijtgesondert, bevelen denselven in sijn offitie alle behoorlijcke eere, respect, hulpe ende faveur te bethoonen, alsoo wij tselve ten dienste van de generale Compagnie ende tot welvaert als onderhoudingh van goede ordre onder de Chinese gemeente alhier sodanigh vinden te behoren.

e. Testament $25 \mathrm{Maart} 1663{ }^{1}$

Op huijden Sondach paessen savonts ontrent negen uren den vijff en twintichsten dach van Meert anno Christi XVI ${ }^{t}$ drie ent sestich compareerde voor mij Jan Keijsers van Breda notaris openbaer bij den $\mathrm{Ed}^{\circ}$ Kaede van Brabant in 's Gravenhage ende in Nederlants India geadmitteert binnen de stadt Batavia residerende ter presentie van de getuijgen naergenoemt, Bingam capiteijn van de Chineesen ende Chinees schepen deser stede, sieckelijck te koij leggende nochtans sijn sinnen ende verstant hebbende ende gebruijckende soo wij notaris ende getuijgen conden oordeelen, die welcke overdenckende de sekere doot en d'onsekere ure van dien heeft daerom met goeden rijpen raede ende deliberatie gemaeckt ende gesloten soo als hij maeckt ende sluijt mits desen sijn testament ende uijterste wille in manieren naer bescreven. Voor eerst recommandeert sijn doot lichaem d'eerlijcke begravinge der aerden, ende comende te disponeren van sijne tijdelijcke goederen die hij testateur deser werelt overlijdende naerlaeten sal, verclaert eerstelijck te legateren aen de Chineese armen deser stede sestich rexd $^{8}$ eens a 60 stuijvers ider, voorders verclaert hij testateur met desselffs huijsvrouwe genaemt Niaij Tuwaetse van Batavia ${ }^{2}$ geen gemeenschap van

1 Landsarchief.

2 Den 26 ${ }^{\text {en }}$ Nov. 1643 teekende ${ }_{n}$ Cap $^{n}$ Bincon" eene notarieele acte van transport waarbij hij aan "Intje Mat Capen van de Maleijers verkocht sijn compts slavinne genaemd T'Toaetse van Batavia ende dat voor de somme van vijftich realen van achten". (Mededeeling van Dr. de Haan). 
goederen off boedel oijt gehadt ende alsnoch niet te hebben, waeromme hij testateur oprechtelijcken verclaert dat sijne huijsvrou voorschr. sonder list off bedroch van haer eijgen middelen verscheijde somme van penningen op interest heeft uijtgeset, ende slaven gecocht waer van op haer eijgen naem obligatien, schultkennissen ende transporten sijn gepasseert, oock verclaert hij testateur dat sijne huijsvrouwe is hebbende verscheijde silverwerck, goude kettings, juweelen, cleetjens als andersints, die welcke mede haer eijgen sijn toebehoorende, ende opdat alle deselve haere goederen in des testateurs boedel niet en sijn begrepen, soo oordeelt hij testateur ende ordonneert bij desen als nootsaeckelijck dat daer van een corten inventaris werde gemaeckt op dat daer over schier off morgen geen questien off moeijten resulteren ende sijne gemelte huijsvrouwe alle de selve als haer eijgen goederen sijnde die behoude ende naer haer neme. Ende vermits hij testateur verclaert dat sijne middelen ende boedel een grooten ommeslach begrijpen ende daer tegens verscheijde importante sommen schuldich is, en daeromme ten hoogsten noodich acht een suffisant, en verstandich executeur, die den gantsen boedel reddere ende de schulden soecke aff te leggen ende te voldoen, soo heeft hij testateur tot dien eijnde versocht en gebeden, dien volgens gestelt, genomineert ende geconstitueert tot executeurs van 't gunt voorschr. is $\mathrm{S}^{r}$ Simon Simons Oppercoopman, Sabandhar en Licentm $^{r}$ in dienst der E. Comp ${ }^{\mathrm{e}}$ binnen deser stede ${ }^{1}$ en Liengsia Chinees des testateurs neve, ende wanneer de lastige schulden van des testateurs naergelaeten boedel sullen hebben vereffent ende voldaen allen het geene alsdan soude mogen comen over te schieten laet ende maeckt hij testateur aen Niaij Tuwaetse sijne huijsvrouwe, ende sijn testateurs kinderen bij haer verweckt bij naemen de 2 soonen Liongsia ende Hongsia ende Pougnio sijne dochter mitsgaders noch aen sijne twee voorsoonen Loenko sijnde vertrocken ende weder staende te comen van Malacca ende Soencko woonende in China, omme alle het overschot van des testateurs naer te laete goederen onder haer allen hooft voor hooft gedeelt te werden, welcken volgende hij testateur verclaert sijne voorschr. huijsvrouwe, ende genoempde sijne vijff kinderen gelijckelijcken int gunt verschr. is te institueren ende te nomineren tot sijne

1 Simon Simonsz, ook genoemd Simon Simonsz van der Heijden, was een Japanner. (Mededeeling van Dr. de Haan). 
erffgenaemen met vollen rechte van institutie. Ten lesten secludeert hij testateur met reverentie ende behoudens het respect d'E. heeren Commissarissen van de Chineese boedels haer E. bij desen van haere goede sorge ontlastende vermits de gestelde curateurs verschr. Allen 't welcke voorschr. is opgelesen ende hem testateur duijdelijcken voorgehouden sijnde verclaerde het selue te wesen sijn uijtersten wille ende begeerte, ordonnerende dat 't selue sal staet grijpen ende effect sorteren 't sij als testament codicil, donatie intervivos vel causa mortis soo als het best can subsisteren en van waerden gehouden worden niettegenstaende eenige municipale oft beschreven rechten ter contrarie alle welcke hij testateur verclaert te derogeren voor soo veel desen sijnen wille naerdeelich sij. Aldus gedaen ende gepasseert ten huijse van testateur in de Theewater straet ten dage, maent ende jaere verschr. ter presentie van $\mathrm{S}^{\mathrm{r}}$ Cornelis Martini coopman ende d'eersaeme Wernard Warniersen beijde borgers binnen deser stede als gelooff waerdige getuijgen hier toe versocht die dese neffens den testateur ende mij notaris hebben onderteekent.

Dit merck is gestelt bij Capiteijn Bingam alsoo door swackheijt van sijn sieckte niet anders teekenen con.

$$
\begin{aligned}
& \text { Cornelis Martini. } \\
& \text { gestelt bij Warnard Warniersen, }
\end{aligned}
$$

Quod Attestor. Jan Keijsers.

Not

Over Bingam's benoeming komt het volgende voor in Bijdragen Kon. Instituut 3e Volgr. VIII (1873): Samuel Sweers, Raad van Indië, 1644, bl. 67 „Haren kapitein Bingam genaamd (een gauw rijk gewezen koopman, die al 23 jaren uit China op Batavia geresideert, veel dingen bij der hand genomen en over de 20 duizend realen, zoo bij de Comp. als zee verloren heeft) is in Februarij 1645, door den Heer Generaal en Raden van Indië in des gestorvene Lacco's plaats, tegen van der Lijn's zin gesteld; daarom na den.Heer Generaals dood, van hem zonder redenen (dikmaals zoo klaagde) kwalijk bejegend, hem af en zijnen favoriet in de plaats te zetten, gedreigd heeft, het welk zich de principaalste Chinezen vrij wat aangetrokken; zulks met UE. verstaan, goed onthaal veel vermag".

Blijkbaar is Bingam na het proefjaar in zijn ambt gecontinueerd; dat hij daarin uitdrukkelijk is bevestigd, is niet gebleken.

Over zijne publieke voorstelling is evenmin iets aangetroffen. $\mathrm{Zij}$ had plaats op 7 Maart 1615, naar uit Bingam's Commissie (IIId) blijkt; 
in het Dagh-Register 1645 zooals dat tot ons is gekomen, wordt over hetgeen te Batavia is voorgevallen, niets vermeld.

Op grond van zijn testament mag worden aangenomen dat hij in China was getrouwd, dat hij bij de daar achtergebleven hoofdvrouw de zoons Loenko en Soencko heeft verwekt en dat zijne „huijsvrouwe genaemt Niaij Tuwaetse van Batavia" eene bijvrouw is geweest. (Volgens Dagr. 15 Dec. 1669, bl. 476 is deze hertrouwd met een tot den Islam overgeganen mesties Pieter Romy).

Dat hij bij zijn overlijden (tusschen 25 Maart en 10 April 1663 - zie IVa) geld aan de Compagnie schuldig was, blijkt uit IVa. In Res. 4 Febr. 1653 wordt van hem gezegd dat zijne geldmiddelen versmolten zijn „in den grooten ommeslach van suijekervelden als anders die [hij] is possiderende", zoodat hij "rechtevoort niet machtig en was de voorsz penningen in éénen clop op te brengen".

Zie nog over Bingam: de Haan, Priangan, II, 412 en III, 9.

Uit Res. 22 Maart 1686 blijkt dat de Christen Chinees Martinus Bingam was aangesteld tot Bode van Boedelmeesters. Volgens eene mededeeling van Dr. de Haan gaf Martinus Bingam, chirurgijn, bij acte 7 Nov. 1678 (not ${ }^{5}$ Dispontijn) eene slavin cadeau aan ${ }_{n}$ sijn swagerinne genaemt Tsinjo van Batavia". Hij onderteekende met een nette Hollandsche hand.

\section{Siqua.}

a. Res. 10 April 1663.

In deliberatie geleijt sijnde is goed gevonden ende verstaen het ampt van de capitain der Chinesen alhier twelke mits het overlijden van den capitain Bingam is komen open te vallen te defereren aen Siqua Chinees ingeseten ende schepen deser stede dewelcke alhier lange jaren geremoreert en sich als een vroom eerlijk burger gedragen heeft, ook onder zijne natie bemint is en waarvan hem commissie in communi forma sal werden verleent met dien verstande dat hij volgens zijne aanbiedingh tot zijnen laste sal hebben te nemen de schulden die de gemelte capiteijn Bingam in zijn leven aen de Compagnie gemaekt heeft.

b. Commissie voor Siqua als capitein over de Chinese burgerij in Batavia (23 April 1663). ${ }^{1}$

Joan Maetsuijcker gouverneur-generael ende de Raden van India wegen den staet der Vereenigde Nederlanden in Orienten, allen dengenen die desen sullen sien ofte hooren lesen saluijt, Doen te weten alsoo door het overlijden van Bingam, gewesen

\footnotetext{
1 Koloniaal Archief.
} 
cappitein, overste ende voorsprake der Chinese ingesetenen der stede Battavia, desselfs plaetse nu vaceert ende hoognodich is dat deselve wederom met een bequaem ende gereputeert persoon bekleet werde, tot welcken eijnde ons voorgekomen is den persoon van Siqua, die veele jaren herwaerts nevens de voors. capitein Bingam in de banck van schepenen dezer voors. stede geseten ende ons goet genoegen gegeven heeft ende onder de voors. ingesetenen in goet aensien is, soo ist dat wij ons van desselfs bequaemheijt ende capaciteijt gecontenteert houde[nde] hem Siqua gestelt ende geauthoriseert hebben, gelijck wij hem stellen ende authoriseeren bij desen als cappitein, overhooft ende voorspraeck der voors. Chineese ingesetenen alhier met soodanige macht ende authoriteijt als sijn predecesseur Bingam heeft gehad, namentlijck om alle kleijne voorvallende saken onder gemelte Chinese burgerie alhier uijt onsen naeme af te doen ende te beslechten ende de groote ofte anders dubieuse te renvoijeren daer 't behoort, mitsgaders voorder te doen wat een goet vroom capitein, overhooft ende voorspraeck toestaet ende betaemt. Ordonneeren ende bevelen aen alle hoge ende lage officieren ende specialijck die van den $\mathrm{E}$. gerechte deser stede den voors. Siqua daervoor aen te nemen en t'erkennen, oock in alle saken sijn officie rakende behoorlijck te maintineren, voorts alle Chinese ingesetenen deser stede, soo die althans hier resideren als die naemaels souden mogen comen, denselven in sijn voors. officie alle behoorlijcke gehoorsaemheijt, eere, respect, hulpe ende faveur te bethoonen alsoo wij tselve ten dienste van de Generale Compagnie ende gerief der gemelte Chinese burgerije sodanig bevinden te behooren.

Gégeven in 't Casteel Battavia den $23^{\text {en }}$ April anno 1663. Ende was onderteeckent: Joan Maetsuijcker, hebbende onder opt spatium van dien Comps zegel in roden lacque gedruckt. Onder tselve stont: ter ordonnantie van hooghgemelte haer $\mathrm{Ed}^{\mathrm{e}}$, geteeckent: Pieter Marville, $\sec ^{\mathrm{s}}$.

c. Dagr. 1663.

23 April. Des morgens werdt Siqua, schepen deser steede en bij resolutie van den $10^{\text {en }}$ deser geëligeert tot capitain der Chineesen alhier in plaatse van den overleden capitain Bingam, in de voors. bediening publijckelijck geauthoriseert op de volgende wijze. 
Nae dat hij met eenige van de aensienelijcste Chineesen in 't Casteel gecomen was, vergeselschapt met een grooten hoop zijde vlaggen en vanen, die haer op 't pleijn van 't Casteel in ordre stelden, is de commissie hem van haar E. tot dien eijnde verleendt, ten overstaen van de heeren gecommitteerdens, den landdrost Jan Ferment, den ontfanger generael Joan Croon, ende den licentmeester Sijmon Sijmons, mitsgaders van twee leden uijt het eerwaerde Collegie van Schepenen, met namen Hendrick Monne, Nicolaes Houman, nevens den secretaris Andries Schellingwou, door den secretaris van haar Ed ed $^{\text {Heeren }}$ Gouverneur Generael ende Raaden van India, Pieter Marville, van de puije voor de heer generael' wooning, ten aenhooren van de ommestanders ende nieusgierige toesienders, openbaarlijck opgelesen en door seeker Chinees in de Chineese tale mede gepronuntieert. Daernae vervoegden sij haer nae binnen bij sijn $\mathrm{Ed}^{\mathrm{t}}$ de heer Gouverneur Generael, die dese nieuwe capitaijn congratuleerde en saluteerde, 't welck gedaen sijnde, reden sij gesamentlijck te peerde uijt het Casteel nae het stadthuijs, alwaer de voors. commissie van de puije noch eens opgelesen wierde door de secretaris Andries Schellingwou, en door den Chinees mede in sijne tale gevolgt. Reden van daer voorts nae het huijs van den nieuwen capitaijn Siqua, staende aen de westsijde van de rivier, alwaer de tafel gedeckt stond ende de heer Niclaes Verburg, president van 't eerwaerde collegie van Schepenen nevens de voorsz. gecommitteerden en andere, gedefroijeert werden.

\section{d. Testament 28 April $1666 .^{1}$}

Tusschen den XXVIII ${ }^{\theta}$ ende XXIX ${ }^{\text {en }}$ April $\mathrm{a}^{\circ} 1666$ des nachts de clocke omtrent een uijren compareerde voor mij Anthonij Huijsman notaris publ. bij den hove van Hollandt ende in Nederlants Indien geadmitteert, resideerende binnen der stadt Battavia, ter presentie van de onder genoemde getuijgen d'Siqua $\mathrm{Capt}^{\mathrm{n}}$ der Chinesen die soo binnen als buijten deser stede sijn woonende, sieck te bedde leggende doch sijne redenen, memorie ende verstant well machtich ende met volcomen uijtspraake gebruijckende alsoo 't opentlijcq bleecq, te kennen gevende dat hij aanmercqten de seeckerheijt des doots ende d'onseeckere wijze van dien, dat hij daeromme beraeden was te maken sijn

\footnotetext{
1 Landsarchief.
} 
testament ende te disponeren van sijne tijdelijcke goederen sulcx ende in der manieren als hijer naer volcht, te weten naer dien hij op de Chinesche maniere off [wijse] getrout is met Niey d' siko van Battavia mette welke hij op sijn Neder[lants] gemeenschap van goederen is hebbende soo hij met ware [woorden] seijde, dienvolgende naer sijn overlijden haer de geregte helft van den geheelen boedell ende goederen (alle de schulden eerst uijtten gemeenen boedel voldaen ende betaelt sijnde) sall competeren ende oock wegens de gemeenschap is competerende, soo ist dat hij nu van sijne helft is disponeerende ende verclaerden dat hij tot sijne eenige ende universeele erffgenaemen genomineert ende geinstitueert hadde soo als hij doet bij desen, sijne vijff kinderen als namentlijk Theenqua Chinees ende Bienio een dochtertje daer moeder aff is ... ta van Bali, Teenqua Chinees daer moeder aff is Toesan van Bali, Teengnio sijnde een dogtertje daer moeder aff is Wedes insgelijcx van Bali, nevens Koqua Chinees woonende in China wiens moeder aldaer is ouerleden, ende dat elcx voor een vijffde $\mathrm{p}^{t}$ in alle de goederen soo roerende als onroerende, actien, crediten ende inneschulden niets ter werelt uijt geseijt $t$ sij waer die gelegen ofte van wien die gecomen souden mogen wesen ende die hij testateur metter doot ontruijmen ende naer laten sall omme alle d'selve goederen ende eenen igelijk van dijen bij de voorn: sijne vijft kinderen (alle de schulden uijt ten geheelen ende gemeenen boedel eerst voldaen sijnde) in vollen ende vrijen eijgendomme aengevaert ende behouden te werden sonder iemants tegenseggen mits dat sijne kinderen voor legaet sullen moeten uijtkeeren aen den Chineschen arme alhier vijftich rijxd ${ }^{\text {drs }}$ à 60 stuijvers ider. Ende stelden hij testateur als opsiende ende regeerende voochdesse over sijne onmondige naer te laten kinderen sijne voorm: huijsvr: Niey d'Siko (schoon sij de moeder van deselve niet en is) met macht dat sij meer voochden tot haer sall mogen adsumeren dewijle sijne meergenoemde huijsvrouw alles volcomen is toe vertrouwende. Alle 't welke voorschr. is hem compt testateur voorgelesen ende well beduijt wesende, verclaerden alle 't selve te wesen sijn testament, uijtterste wille, meeninge ende begeerte, willende ende begeerende dat desen volcomen effect sorteren ende cracht grijpen sall tsij als testament, codicille, gifte uijt saake des doots ofte eenige andere uijtterste wille sulcx 't selve best naer rechten ofte andersints sall mogen subsisteren al 
waren alle behoorlijcke solemniteijten in desen noodich, geommitteert bevonden mochten werden, imploreerende tot dien eijnde de hulpe ende het offitie van allen rechten ende rechteren. Aldus gedaen ende gepasseert binnen deser stadt ten huijse ende voort sieckbedde van den testateur ter presentie van $\mathrm{S}^{\mathrm{r}}$ Abelus Benting, onder coopman in dienst der E. comp ${ }^{\circ}$ ende Jasper Huijbers mijnen clercq: als getuijgen hier toe versocht ende gebeden.

$$
\ldots{ }^{1}
$$

Gestelt bij d'Siqua, Chinees

Abelus Bentingh.

J. Huijbers.

1666.
A. Huijsman.

1666. Nots.

In eene Res. van 9 Mei 1626 wordt gezegd dat „Zansiqua” met zijne jonk uit China te Batavia is aangekomen; "Zieequa, Chinees" teekent 12 Dec. 1643 eene notarieele acte. In beide gevallen kan dit de latere Kapitein zijn geweest. Vermoedelijk heette deze Gaan Dzi (dzi = twee; $\mathrm{kwa}$ is alleen een beleefdheidsterm, niet een deel van den persoonsnaam). Siqua was Schepen van 1643 tot zijn dood. (Valentijn, IV, 1).

Hij overleed tusschen 28 April 1666 toen hij zijn testament maakte en 29 Mei 1666 (Dagr.).

Uit zijn testament blijkt dat Siqua in China is getrouwd geweest en uit dit huwelijk een zoon had. Tevens was hij te Batavia gehuwd met "Niey d'Siko" (wier eigen naam niet wordt genoemd), uit welk huwelijk geene kinderen in leven waren. Deze „weduwe Siqua", heeft van 16661678 de functie van Kapitein der Chineezen waargenomen. (Zie over haar: De weduwe van Kapitein Siqua, in Chung Hwa Hui Tsa Chih, October 1918, bl. 16 e.v.).

Nieuhof, die o.a. van 20 Juli $1667-17$ December 1670 te Batavia was (zie Mr. J. F. Bodel Nijenhuis in Nijhoff's Bijdragen N.R., III, 42), zegt in zijne Zee- en Lant-Reize, Amsterdam 1682, bl. 226 b, het volgende: „Buiten de nieuwe poort rontom in lustigh geboomte, ziet men een grafstede, door de Sinesen, na hunne wijze prachtigh gebouwt, ter eere van hunnen oppervoogt Sequa. Het bestaat in een heuvel met opgeworpe aerde daer voor, en in verscheide metselwerken die alle wit gepleijstert zijn. In het midden staet een tafel, met een kan daer op, daer de Sinesen t'elkens het een of ander, 't zij spijze of gelt, insmijten, tot zoene van de ziele der overledenen".

Dr. C. Swaving vermeldt in: Batavia's sanitaire geschiedenis onder het bestuur van de Oost-Indische Compagnie, bl. 67: „Niet ver van het beschrevene verblijf [n.l. het Gezantenverblijf buiten de Nieuwpoort, aan de rivier van Jacatra] prijkte ter gedachtenis van den Chineeschen leeraar Sequa, een prachtige grafstede".

Uit de beschrijving van deze graftombe schijnt te moeten worden opge-

1 Eenige met zeẹr zwakke hand getrokken krabbels, 
makt dat zij is opgericht voor den persoon genoemd in het volgende bericht: „In deze dagen (1672) gingen de Chineezen op ons schip, omstreeks 30 in getal, naar Canton en onder hen een van hunne bisschoppen die op Batavia geweest was om toe te zien dat de daar wonende Chineezen niet zouden aposticeeren; de naam van dezen Bisschop was Sequa" (Friderici Bollingii, Oost-Indısch Reisboek. Bijdr. Kon. Inst. 68 (1913) bl. 370).

Nieuhof kan echter dit graf niet zelf hebben gezien.

Dat ook Kapitein Siqua's graf iets buitengewoons was, volgt uit hetgeen Heydt (Allerneueste Geogr. u. Topogr. Schau-Platz enz. 1744, bl. 114) hierover zegt: „Ehedessen haben die Capitains derer Chineesen auch einen Sitz unter dem hohen Rath in Batavia gehabt; [bedoeld zal zijn dat zij in de bank vau Schepenen zaten] in meinem Dortsein wurde mir ein kostbares Begräbnisz gezeiget, worinnen der letzte Capitain noch so in dem Rath gesessen, begraben seijn soll".

Het graf dat thans nog aanwezig is op een erf aan Molenvliet Oost (kampong Kebon Djeroek) is stellig niet het graf van Kapitein Siqua. Misschien was „Gaan Soen Tsai” die daar 1706 begraven werd, de bekende Gaan Tenqua, zoon van Siqua en van eene Balische vrouw Toesan.

Siqua's weduwe te Batavia, overleed vermoedelijk 22 Dec. 1678 (zie rekesten van haren erfgenaam behandeld bij Res. 29 Juni 1694 en Res. 27 Juli 1694). Siqua's zoon Tenqua ,de zoon van den overleden Capiteijn der Chinesen Siqua en ingezeten alhier" wordt toegestaan (Dagr. 1676, bl. 100) ,,met onse schepen naar Hocksieu [de hoofdstad der provincie Hokkian in China] over te varen onder de suite van ons volck omdat hij in de Duijtsche tale te spreecken en schrijven oock seer ervaren is en misschien daerom wel eenighe dienst kunnen doen zouw"; 14 April 1678 behoort Tenqua tot „de principaelste ingeseten Chinesen" en 15 Febr. t.v. werd hij daartoe blijkbaar ook gerekend (Zie Dagr. op die data).

Bij Res. 16 Mei 1679 wordt vermeld dat tot sergeant en schrijver is verkozen „Gantencqua, soone van den overleden Capiteijn Siqua, zijnde in onse als andere talen, ten meerendeele hier gebruijckelijck, ervaren en daarom veeltijts elders kan te passe komen".

In Dagr. 23 Juli 1680 wordt hij gerekend tot „onse hooffden der Chinesen".

Bij eene obligatie d.d. 5 Juni 1666 (notaris Huijsman) verklaart een Chinees schuldig te wezen aan „Nieij d'Siko wedue van den overleden d'Siqua, Chinees, in zijn leven Capt $^{\mathrm{n}}$ der Chinesen alhier" 50 rijksd. à 60 stuivers. Deze obligatie wordt in margine geroijeerd door G. Thenqua als „erffgenaem van de creditrice" (Mededeeling Dr. de Haan).

3 Sept. 1696 was hij nog in leven. Zie over hem nog De Haan, Priangan III, 272 (1).

Misschien waren Gan Tongko en Gan Tjoenio, eenige kinderen en erfgenamen van Gan Hoenko, afstammelingen van Kapitein Siqua. Zij verzochten ontheffing van het in 1679 gelegde en bij hunne eigendomsbrieven in dato 16 Sept. 1761 vermelde altoos durend verband op twee stukjes tuinland, naast elkander gelegen, omtrent een half uur gaans buiten de stad, aan de Oostzijde van Molenvliet, in het Westerveld, het 2• deel van Blok M. (Res. 29 April 1777).

Over de voorwaarde dat de opvolger de schuld moest overnemen welke zijn voorganger aan de Compagnie had (bl. 22, IVa) zie: De Haan, Priangan III, 787, 789 . 


\section{Tsoa Wanjock.}

a. Res. 14 Juni 1678 .

Naerdemael het Capitainschap der Chinesen te deser stede, na het overlijden van Siqua, zedert den jaere 1665 tot nu toe is vacant gebleven en soo lange ten principalen, bij desselfs weduwe waergenomen, ende dat ons nu, zedert eenigen tijt herwaerts, verscheijde versoecken en requesten der oudste en meeste ingesetenen der Chinesen, sijn voorgecomen, omme gelijck in vorige tijden weder een man en niet langer een wijff, tot hooft over haere natie te mogen hebben, soo als sulcx omtrent de andere inlantse ingesetenen mede wert geobserveert, ende 't welcke oock inderdaad voor 't gemeene beste niet ondienstigh geaght maer nodigh geoordeelt wert. Soo is t dat althans, naer verscheijde voorgegane consideratien, goetgevonden zij: tot de electie van een nieuw Capitain en hooft der Chinesen te deser plaatse te treden; en waer toe dan als de bequaemste verkoren is, Tsoa Wanjock zijnde een van de oudste inhabitanten, die hier over de 40 jaeren heeft gewoont en onder hunne natie wel de recklijckste, beminste en voornaemste geacht, als oock zijn intrest, soo binnen als buijten de stadt, van belangh gehouden wert.

Dogh nadien de versoecken der Chinesen mede tenderen, omme nevens een capitain, oock met de verdere mindere hooftofficieren te mogen werden vereert, soo zijn daertoe, uijt die meest in bedenken komen en insgelijcks voor de oudste en aengenaemste schijnen te werden aengesien, verder genomineert en gestelt: Limsi Saij, tot luijtenant en Litsoeko tot vaendrigh.

Met welcke verkiesingh men dan vermeijnt dat de Chinesen int generael, wel sullen wesen gecontenteert ende nu oock in te beter ordre konnen werden gebragt, omme bij eenige voorvallende ongelegentheijt tot bescherminge van dese stadt en landen, nevens andere inlanderborgers te dienen en waer toe zij sigh selven al eenigsins vrijwilligh hebben schijnen aen te bieden.

\section{b. Dagr. 29 Juni 1678.}

Heden voor de middach ontrent de clocke negen uijren met een groote swier en toeloop van de Chinese ingesetenen, nae haer wijse op het best uijtgedost, met veel vaenen ende en- 
ckelde zijde boogen van verscheijde couleuren onder gespeel van allerhande chinese instrumenten binnen 't Casteel verscheenen wesende de chinesen Tsioa Wanjock, Limsisaij en Litsoecko, op den 14 deser in Rade van India geëligeert tot capiteijn, lieutenant ende vaendrich over die van haere natie alhier remorerende, soo zijn deselve, na een cleen wijltje binnen bij Zijn Ed. geweest hebbende, weder buijten gecomen tot op de puije van de groote voorzaal en aldaar in presentie van de $\mathrm{E}^{\mathrm{d}}$. fiscael van India mitgaders den balliuw en landdrost benevens twee gecommitteerde schepenen solemnelijck in haere respective qualiteijten ende functien geauthoriseert, zijnde de commissie, tot dien eijnde op deselve gedecerneerd, eerst in onse tale opgelesen door den coopman Joan van Hoorn, eerste clercq ter generaele secretarije, ende daernae door den chinees coopman Tenglauw in de Chinese taele, luijdende van woorde te woorde aldus :

Rijcklof van Goens, Gouverneur Generael ende de Raden van India wegens den staet der Generale Nederlandse Geoctroijeerde Oost-Indische Comp. in Orienten, allen dengeenen die desen sullen sien of te hooren lesen, saluijt; doen te weten:

Alsoo het capitainschap der Chinese ingesetenen te deser stede Batavia nae het overlijden van Siqua zedert den jare 1665 tot nu toe is vacant gebleven en ten deele doorgaens' bij desselfs weduwe waergenomen en dat ons nu wederom zedert eenige tijt herwaerts verscheijde versoecken ende requesten der oudste ende meeste Chinese ingesetenen zijn voorgecomen omme gelijck in voorige tijden weder een man ende niet langer een wijf tot hooft over haere natie te mogen hebben, ende hetwelcke oocq inderdaet voor het gemeene beste noodich geoordeelt wert, soo is 't dat, daerop jegenwoordich gedelibereert wesende, in onsen Rade goetgevonden zij, uijt diverse voorgestelde Chinesen wederom als capitaijn, overhooft ende voorspraacke derselver Chinese natie alhier ter stede te nomineren ende te verkiesen den persoon van Tsioa Wanjock, hebbende hierover de 40 jaren gehabiteert ende van wiens bequaembeijt ende bemintheijt onder die ingesetenen wij ons gecontenteert zijn houdende, gelijck wij denselven Wanjock dan oocq tot capitain der Chinesen alhier nomineren, stellen en authoriseren bij desen, en verders op 't voordragen der meergezeijde Chinese 
natie en tot zijnen hulpe ende adsistentie daer noch hebben bijgevoecht Limsisaij tot lieutenant ende Litsoeko tot vendrich, met soodanigen macht en authoriteijt voor gemelte capiteijn Wanjock, als zijnen praedecesseur Siqua heeft gehad, namentlijck omme met communicatie zijner voorseijde twee minder officieren alle cleijne voorvallende zaken onder de Chinese burgerije alhier uijt onsen name aff te doen ende te beslechten, ende groote off anderssints dubieuse te renvoijeren daer 't behoort, mitsgaders verders alles te doen wat een goet, vroom, wacker capitain, overhooft en voorsprake toestaet ende betaemt. Ordonneren ende bevelen derhalven aen alle hooge ende lage officieren, ende speciaelijck die van den E. gerechte deser stede, den voorsz. Tsoa Wanjock daervoor aen te nemen ende te erkennen, oocq in alle zaken zijn officie raackende behoorlijck te maintineren, ende voorts aen alle Chinese ingesetenen deser stede, soo die althans hier resideren als die naemaels souden mogen comen, denselven in zijn voorsz. offitie alle behoorlijcke gehoorsaemheijt, eere, hulpe ende faveur te bethoonen ende te bewijsen, alsoo wij sulcx ten dienste van de Generale Comp., gerieff ende welstant der gemelte Chinese burgerije alhier, soodanigh bevinden te behooren.

Gegeven tot Batavia in 't casteel, op 't eijlandt Groot Java, den 29 Junij anno 1678.

(was geteijckent:)

Rijcklof van Goens.

(Terzijden stont 's comp zegel in roode lacke gedruct ende daeronder:)

Ter ordonnantie van hooghgemelte Haar Ed.

$$
\begin{gathered}
\text { (was geteijckent:) } \\
\text { Joan van Hoorn. E clercq. }
\end{gathered}
$$

Dit dus dan gedaen ende deselve luijtkeels met een gemeene toestemminge op gedaene affvraginge bij haere natie aengenomen zijnde, wierden se weder nae binnen in de camer van $Z i j n ~ E d^{t}$. den Heere Gouverneur Generael geleijt, alwaer hun dan nae een weijnich vertoeven de voorenstaende opene lastbrieff wiert overhandicht, als wanneer se nae verkregen affscheijt door de voor geciteerde officieren en gecommitteerde te stedewaert in nae het stadhuijs wierden geconduiseert, alwaer dan weder dese commissie andermael door den secretaris van Heeren Schepenen 
Jacob van Dam, ende voorts door den chinees coopman Tenglauw den volcke voorgelesen zijnde, vertrock men vandaer soo te voet als te paerde onder het geclanck van allerhande gespeel nae de wooninge van den capitain Wanjock voormelt, daer een tafel gedect stont ende de gecommitteerde ende 't verdere geselschap eerlijck op een collation wierden onthaelt, ende waernae dan een ijder sich matelijck vervroolijckt hebbende weder nae huijs keerden.

c. Dagr. 5 Oetober 1684 .

'S voormiddags werd den Chinesen Capitain Wanjock hooft over alle de Chinesen alhier ter stede remorerende op den.... overleden als nu met bijsonderlijcke, en grote statie na de maniere onder die natie gebruijckelijk begraven, en buijten de stadt in het daartoe gemaeckte Chinese graf ontrent Noordwijk ter aarde bestelt, gaande voor uijt de comp ${ }^{e}$ militairen deses Casteels, ${ }^{1}$ werdende opgevoert door den Luijtenant Jan de Moor, alle met rouwbanden en cherpen versien, marcherende met slepende geweiren na militair gebruijk, daarop volgde als doen de Chinese statie.

Tsoa Wanjock werd benoemd tot Boedelmeester in de jaren 1661-1662, 1664-1665, 1669-1676.

Zijn zoon Tosiong, Toesiong of Tesiong wordt vermeld in Dagr. 1680, bl. 95,464 en 475 .

Wegens schuld aan wijlen G. G. Speelman zat ,de huijsvrouw van Tosiongqua, sone van den gestorven $\mathrm{Cap}^{\mathrm{n}}$ der Chinesen Tsoa-wanjok in gijzeling". (Res. 12 Juli 1689).

\section{Queeconko.}

a. Res. 3 Aug. 1685.

Wijders gedelibereert zijnde, wie men uijt de voornaemste Chinese ingesetenen deser stede wederom soude verkiesen tot Capitain ende Lieutenant respectivel[ijk] van deselve natie, in plaets van den overleden capitain Tsoawanjock ende lieutenant Couko $;^{2}$ Soo is na gedane omvrage, besloten wederom tot ca-

1 De compagnie des kasteels was de fine fleur van het garnizoen, ook in kleeding onderscheiden van de rest. (Mededeeling van Dr. de Haan).

2 Oeij Koeko. 
pitain aen te stellen den Chinees Queconko, hebbende een geruijmen tijt voor de Bantamse troubles aldaer het gesag met goede getuijgenis over de Chinesen gevoert, mitsgaders tot lieutenant den Chinees Quepauko, over eenige maenden tot Boedelmeester der Chinese ende andere vreemde sterfhuijsen gekozen zijnde ${ }^{1}$, met welcke beijde personen geoordeelt wert dat de sake dier natie na behoren sullen werden gehandelt en gehanthaeft.

b. Res. Saturdag den $4^{\text {en }}$ Augusti 1685 na 't avondgebet.

Extraordin ${ }^{\mathrm{s}}$ vergadering.

Is door d'heer Gouverneur Generael voorgelesen seker request hedenmorgen aen sijn Ed door den Chinees Queconko op de bekentmakinge van sijne verkiesinge tot capitain over de Chineesen ter hant gestelt, om daervan te mogen werden geexcuseert ter sake, (soo hij aldaer voorgeeft) van sijne onbequaemheijt ende onmagt tot de bedieninge van dat ambt, waer na sijn Ed $^{t}$ nog verhaelde dat er uijt gemelte capitains discoursen genoegsaem was te bespeuren geweest dat dese geallegeerde onbequaemheijt bij hem alleenlijck tot een discreet voorwendsel gebruijckt ende hij wel meest ende alleenlijck tot dat versoeck van excuse bewogen was door een vreese die hij soude geset hebben uijt de jongste onverwagte ende suspecte doot van den Chineesen lieutenant Couko ende den boedelmeester Bousiqua, ${ }^{2}$ beijde in haer leven seer apparent gestaen hebbende tot dese bedieninge van capitain ende waervan de presumtien ende gevoelens al seer sterck gelopen hadden, dat sij beijde welligt door een violente dood souden sijn gesturven, om alsoo de verwagtinge van den gewesen Chinesen boedelmeester Jouko alias Quedsiqua, bij resolutien van $30^{\text {n }}$ Januarij en $23^{n}$ Februarij deses jaers al eenigsints genoteert staende, te apparenter te maken, dog dat gemelte nieu verkoren Chinees Queconko egter naderhant op sijn $\mathrm{Ed}^{\mathrm{s}}$ persuasie verklaert had dese aen hem gedefereerde digniteijt, in erkentenis van de estime ende gunste der Vergaderinge tot hem te sullen accepteren onder hope ende vertrouwen nogtans, dat niet lange na desen op sijne ontslaginge soude werden gedisponeert.

1 Res. 2 Juni 1685.

$2 \mathrm{Hij}$ overleed vóór 31 Juli 1685. 
c. Res. 30 Januarij 1685 .

Den Chinesen Boedelmeester Quedsienqua alias Jouko doet bij requeste versoeck om te mogen hebben copie van seker request door sekere Chinesen met namen Ong Ouko, Iotsounqua, Iapsitko, Hosoenqua, Niopequa, Khouheengko, Himpeko, Kimseeng, Angtionko, Khouloeko, Tansianko ende Licounko jongst ingelevert ende verscheijde pointen van beschuldiging ten sijnen laste behelsende, opdat hij sig daer tegens moghe verantwoorden, waerover gedelibereert ende geconsidereert sijnde dat het geen sake van dese tafel maar eigentl. van de Justitie is, goetgevonden is in plaets van sijn versoeck toe te staen, copie van het laetstgemelte request of geschrift van beschuldiging te senden aan den Bailliu deser stede, om sig op den inhoude desselfs exactel. te informeren, en wijders tegen dengenen daertegen het behoort, het regt van de ho: overheijt waer te nemen, mitsgaders hem Quedsienqua ter gelegener tijt daervan eerst copie te geven.

\section{d. Res. 23 Februarij 1685 .}

Den Chinees Ong Ouko die voor eenige weken nevens meer andere Chinesen bij requeste aen ons verscheijde beschuldigingen ingebragt heeft ten laste van den Chinesen boedelmeester Quedsienqua alias Jouko, 't welcke volgens resolutie van den $30^{\text {en }}$ Januarij pass $^{\circ}$ goetgevonden is in handen van den bailliu te stellen om 't regt van de ho: overheijt in die sake waer te nemen, komt nu wederom bij requeste klagen dat hij door gemelten Quedsienqua onlangs in sijn eijgen huijs violentelijk aangetast ende geslagen was geworden omdat hij van hem wederom geeijst had vier stux goude coubangs die hij Quedsienqua over 4 jaeren van hem met eenige goederen uijt China komende, genoten had om se door de boom in te brengen, 't welck egter doe[n] niet geschiet was maer in tegendeel bijna waren door de E. Comp. afgehaelt ende gekoft, ende waervoor hij aan voorsz. Quedsienqua nog boven de voors. 4 goude coubangs had moeten betalen een somma van vijf en vijftig rds, versoekende dat hem Quedsienqua mogt geimpungeert werden hem supplt, die hij nog weder gedreijgt had te sullen laten bastonneren, ongemolest ${ }^{t}$ te laten, Waer over gedelibereert sijnde verstaen is oock copie van dit request te doen stellen in handen van den bailliu deser Dl. 78 . 
stede om hierop verders te inquireren en voorts in dese sake soodanig te handelen als bevonden sal werden te behoren.

e. Batavia, den $7 \mathrm{Aug}^{\mathrm{s}} 1685$.

Johannes Camphuijs, Gouverneur Generaal ende de Raden wegens den staat der generale Nederlantse geoctroijeerde Oost Indische $\mathrm{Comp}^{\mathrm{e}}$ in Orienten, allen dengenen die desen sullen sien ofte hooren lesen, Saluijt, doen te weten:

Alsoo het Capitainschap der Chineese ingesetenen te deser stede Batavia, vermits het overlijden van den $\mathrm{Cap}^{\mathrm{n}}$ Tsoa-Wanjock voorleden jaar is komen vacant te worden, en dat ons tsedert eenige tijt herwaarts, verscheijde versoecken ende requesten der oude en meeste Chinese ingesetenen sijn voorgekomen, omme weder een bequaam man tot hooft over haere Natie te mogen hebben, hetwelcke oock inderdaat voor die gemeente goet en nodigh geoordeelt wort; Soo ist dat daarop gedelibereert wesende, in onsen rade goetgevonden sij, uijt diverse voorgestelde Chineesen wederom als $\mathrm{Cap}^{\mathrm{n}}$, opperhooft en voorspraacke derselver Chineese Natie alhier ter stede te nomineren ende te verkiesen den persoon van Quekonko, hebbende voor de Bantamse revolutie het Capiteijnschap over de Chineesen aldaar woonende verscheijde jaaren tot contentement van deselve, en met goede getuijgenissen bekleet gehadt, ende tsedert alhier terwoon gekomen, mede betoont van de vereijste qualiteijten ende bequaamheden daartoe te sijn, gelijck wij denselven Quekonko dan oock tot Capiteijn der Chineesen alhier nomineren, stellen, en authoriseeren bij desen, en vorders op 't voordragen der meergeseijde Chinese Natie en tot sijner hulpe en adsistentie, in plaats van den mede overleden luijtenant Couko, daar nog hebben bijgevoegt de Chinesen Quepauqua tot eerste en Limkeeko tot tweede luijtenant, onder continuatie van den tegenwoordigen vendrigh Tsoa Tenglau: met soodanigen magt ende.authoriteijt voor gemelte Que Konko, als sijnen predecesseur Tsoa Wanjok heeft gehad, namentlijck omme met communicatie sijner voorseijde drie mindere officieren, alle kleijne voorvallende zaacken onder de Chinese burgerije alhier, uijt onsen name aff te doen ende te beslegten, dog de groote off andersints dubieuse te renvoijeeren daar't behoort, mitsgaders verder alles te doen, wat een goet, vroom en wacker Capitain, opperhooft en voorspraack toestaat en betaamt, Ordonneren 
ende bevelen derhalven aan alle hooge en lage officieren, en specialijck die van de E. geregte deser stede, den voorsz. QueKonko daar voor aan te nemen, en te erkennen, oock in alle[s] sijn officie raackende behoorlijck te maintineren ende voor te staan, Vorders aan alle Chinese ingesetenen deser stede, soo die althans hier resideren als die namaals nog souden mogen komen, denselven in sijn voorsz. officie alle behoorlijcke gehoorsaamheijt, eere, hulpe ende bijstant toe te brengen ende te bewijsen, alsoo wij sulx ten dienste van de Generaele Compagnie en het gerieff en welstant der gemelte Chinese burgerije alhier, soodanigh bevinden te behooren.

Gegeven in 't Casteel Batavia op 't eijland Groot Java den $7^{\text {n }}$

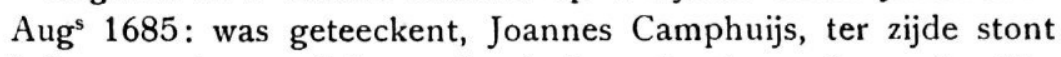
's Compagnies zegel in rooden lacke gedruckt en daaronder: Ter ordonnantie van hooggemelte haar $\mathrm{Ed}^{\mathrm{s}}$ - was geteeckent: A. van Riebeeck. Secrets.

\section{f. Dagr. 7 Augustus $1685 .{ }^{1}$ )}

Heden den geprefigeerden dag tot de publijcque aucthorisatie van $\mathrm{Zijn} \mathrm{Ed}^{\mathrm{t}}$ de heer Gouv ${ }^{\mathrm{r}}$ Generael Joannes Camphuijs gekomen zijnde, soo wierd al vroeg in den morgenstond door den heer President Francois Tack op 't pleijn binnen 't Casteel in volle wapenen gestelt de Compe militairen te voet ende ruijterije deses Casteels, waarna omtrent de klocke agt uijren hier binnen, en op de voorzale van des Generaels wooninge zig vervoegden alle de collegies, gequalificeerde Comp ${ }^{\text {es }}$ dienaren, en borgeren (op gisteren door diverse ordonnantien, onder handteijckeninge van den $\mathrm{E}$. Secretaris $\mathrm{M}^{\mathrm{r}}$ Abraham van Riebeek geciteerd) welckers namen hiervorens onder dato $31^{\text {en }} \mathrm{Julij}$ staen gespecificeert, als wanneer hooggem. zijn $\mathrm{Ed}^{t}$ door de gesamentlijke heeren Raden van India Anthonij Hurt, Willem van Outhoorn, Marten Pit, Cornelis van Quaalbergh en Joan van Hoorn, item den heer oud Extraordr Raad van India Anthonij Pavilioen en den E. Secretaris Abraham van Riebeek na de raadcamer wierd geconduiseert, alwaer zijn $\mathrm{Ed}^{t}$ met de presente heeren Raden op hun gewoone sitplaatsen, en $d^{\prime} h^{r}$ Pavilioen op een wat van de tafel afstaande stoel schuijns aan de regter zijde van zijn $\mathrm{Ed}^{t}$ terneder geseten zijnde, soo wierde voor eerst door den E. Secre-

1 Landsarchief (ongecollationeerd afschrift). 
taris $\mathrm{M}^{\mathrm{r}}$ Abraham van Riebeek binnen geroepen 't collegie van den agtb. rade van Justitie, 't welk zig ter slinckerhand der raattafel, onder haaren president $\mathrm{d}^{\prime} \mathrm{h}^{\mathrm{r}}$ ordinaris raad Willem van Outhoorn, na overleveringe der zegels, nevens de fiscaals, mitsgaders den Secretaris en deurwaerder geplaatst, ende ijder van henlieden den eed tot hare respective ampten behoorende, en bij de Batavise statuten vervat, aan handen van zijn $\mathrm{Ed}^{\mathrm{t}}$ afgenomen zijnde, soo wierden vervolgens bij beurten mede binnen geroepen de verdere collegies van heeren Schepenen, Weesmeesteren, Heemraden, Commissarissen van huwelijxe en cleene saken, Boedelmeesteren der Chinesen ende andere vreemde sterfhuijsen, onder hare respective presidenten, ende na 't overleveren al mede van hunne zegels gecontinueert op de eeden, door haar in 't aanvangen hunner bedieningen dit en 't voorige jaar, reets aanhanden van hooggedagte $\mathrm{Zijn} \mathrm{Ed}^{t}$ gepresteerd, waar na alle deselve, nevens den eerw. kerckenraad en d' broederen diaconen, binnen geroepen ende aan de slinckerhand der raadtafel gegaen zijnde, soo wierden vervolgens nog gesamentlijk binnen geroepen en aan de andere zijde geplaatst, de gequalificeerde Comp $^{\text {es }}$ dienaren, soo van de negotie als militie ende zeevaard, item nogh aan de slinckerzijde, beneden de voorschr. collegies, de voornaamste burgeren deser stede: als wanneer henlieden alle de opgestelde en op $31^{\text {en }}$ Julij gearresteerde acte van aucthorisatie gelesen, ende daar op aanstonts bij henliede alle op de afvraginge van $\mathrm{d}^{\prime} \mathrm{Ed}^{\mathrm{e}}$ heer Directeur generael Anthonio Hurt den algemeene Eed van getrouwigheijt na gedane voorlesinge aanhanden van zijn $\mathrm{Ed}^{\mathrm{t}}$ gepresteerd, en hooggemelte zijn $\mathrm{Ed}^{t}$ daarop door de heeren Raden en alle de omstanderen in dit hoogwigtig en aansienlijk ampt gecongratuleerd, krijgende kort daar aan de respective heeren presidenten de zegels harer collegies, mitsgaders den E. president Francois Tack ende den E. balliuw Jacob Casembroot de sleutels van dit Casteel en de Stadt wederom, die zij mede in 't binnen comen aan zijn $\mathrm{Ed}^{t}$ ter hand gestelt hadden, waar mede dan dese voorstellinge binnen de raadcamer is besteld, en ' $t$ gandsche geselschap genodigd, om deselve 's namiddags op 't Theatrum voor dit Casteel, mitsgaders voor ende in hare resp. compagnien bij te woonen; zijnde wijders de gemelte acte van hooggemelte zijn $\mathrm{Ed}^{\mathrm{ts}}$ aucthorisatie benevens den algemeenen eed van getrouwigheijt van volgenden inhoudt: 
De Raden wegens den staat der Generale Nederlandse geoctroijeerde Oostindische Comp. alhier te lande allen dengeenen die dese tegenwoordige sullen sien ofte hooren lesen saluijt, doen te weten:

Alsoo door het afsterven van zijn $\mathrm{Ed}^{\mathrm{t}} \mathrm{d}^{\prime}$ heer Gouv ${ }^{\mathrm{r}}$ Gener ${ }^{1}$ Cornelis Speelman L. M. op den $11^{\text {en }}$ Januarij des verleden jaars 1684 't generale gouvernement van Nederlants India van een Gouverneur Gener ${ }^{1}$ ontbloot geworden is en die hooge en aansienelijke bedieninge mitsdien comen te vaceeren, in welcken gevalle de ordre en instructie ran onse principale d' Ed ${ }^{e}$ Heeren gecommitteerde Bewinthebberen ter vergaderinge van $d^{\prime} 17^{\mathrm{e}}$ in den jare 1617 geconcipieert, en bij resolutie van hare ho. mo. de heeren Staten der vrije vereenigde Nederlanden onse souverainen geconfirmeert zijnde, is mede brengende dat aanstonts sonder het minste uijtstel ofte dilaij, en zulx op staande voet na het overlijden van den persoon van den Gouv ${ }^{r}$ Generael, uijt de aanwesende Raden de capabelste en bequaamste, provisionelijk en op approbatie van onse Heeren Majores tot het hoogwigtig ampt van Gouvr Generael gepromoveert en verkose werden, Soo ist dat wij in nacominge van haar ho. Ed $\mathrm{den}^{\text {ens }}$ gemelte ordre en behage, tot betragtinge van den gemeenen welstant deser landen en om op 't vacerende gem. Gouvernement de vereijschte ordre te stellen, op staande voet ons ter ordiro vergaderzale vervoegt, en de name des Alderhoogsten aangeroepen hebbende om op soo een emportante en hoogwigtige chargie met rijpen verstande te disponeren, mitsgaders ten dien eijnde ook gesamentlijk gepresteert en afgelegt hebbende den eed voor de Raden van India beraamt, vervolgens geconsidereert en aanmerckinge genomen hebbende de goede qualiteijten mitsgaders daartoe gerequireerde kennisse en ervarentheijt in den persoon van d' $E$. heer doenmaals Ordinaris Raad Joannes Camphuijs door lange diensten en verscheijde digniteijten en illustre charges geacquirt, oversulx bij resolutie van gem $^{\text {te }}$ dage goet gevonden en gearresteert hebben de $\mathrm{Ed}^{\mathrm{e}}$ heer Joannes Camphuijs tot Gouverneur Generael van Nederlants India, op approbatie van hooggedagte onse heeren en $\mathrm{m}^{\mathrm{rs}}$, te nomineren en te verkiesen waarvan dan vervolgens bij missive van den $19^{\text {en }}$ Februarij daar aanvolgende met de retourvloot onder de vlagge van den Commandeur Jozephas Vos notificatie aan haar ho. $\mathrm{Ed}^{\mathrm{s}}$ gedaen, en de gerequireerde approbatie daarop versogt zijnde, het gemelte haar ho. Ed $d^{e}$ gelieft heeft gehad de voornoemde verkiesinge en 
aanstellinge van den $\mathrm{Ed}^{\text {en }}$ Heer Joannes Camphuijs tot het illustre en hoogwigtige ampt van Gouv ${ }^{r}$ Generael deser Indische gewesten in allen dele te confirmeeren, en te aggreeren agtervolgens den teneur van haar ho. Ed ${ }^{\text {ens }}$ generale missive op $11^{\text {en }}$ December 1684 uijt Amsterdam aan ons geschr. en met de fluijt Emmenes voor de eerste mael hier aangebragt zijnde, luijdende in extract aldus:

De provisionele aanstellinge van den heer Joannes Camphuijs tot Gouv ${ }^{r}$ Gener $^{r}$ hebben wij ons volcomentlijk laten gevallen eligerende hem daartoe dan ooq bij desen in vertrouwen dat zijn E. hem in desen eminente ende nietmin swaarwigtige bediening, zoodanig zal evertueeren en quijten, als wij dat van hem zijn verwagtende, en vooral dat zijn $\mathrm{E}$. sonder ophouden daar toe zal arbeijden om alies weder te krijgen in staat als dat behoort, en bijsonderlijk mede dat de ordres bij ons gegeven en nogh te geven punctuelijk mogen werden nagecomen, mitsgaders de wetten die van tijt tot tijt zijn gemaakt, en in een nauwe observantie gebragt.

Ingevolge dan van alle 't gene voorschr. is, in Rade van India goet gevonden zijnde de nodige voorstellinge en aucthorisatie van den hoogE. gemelten heer Gouv ${ }^{r}$ Generael Joannes Camphuijs aan allen den welcke ${ }^{1}$ niet langer op te houden maar op heden te laten geschieden ten eijnde een ijgelijk van allen desen bewust zijnde, weten mogen wie hij, gelijk tot nu toe soo oocq voortaan na desen, voor zijn wettigen Gouv ${ }^{r}$ Generael en opper gebieder te respecteren en te gehoorsamen heeft.

Soo ist dat wij dan bij desen alle Raden van. India, Gouverneurs, Admiraals, Officieren en Collegien van Justitie, Directeurs, Commandeurs, Oppercooplieden, Cooplieden, Capitainen, Schippers, Luijtenants, ondercooplieden, vendragers, adsistenten, mindere bediendens, soldaten, matrozen, borgeren, en voorts alle andere ministers, soo te water als te lande, onderdanen en ingesetenen, in den dienst of onder 't resort van de Generale Nederlandse Oost-Indische Comp. en onder desselfs eed, mitsgaders de gehoorsaamheijt d' ho. mo. heeren Staten Generael, tegenwoordig in India zijnde en die daar na desen successivelijk nogh zullen mogen aancomen, bij desen ordonneeren en bevelen hoogh gemelte zijn $\mathrm{Ed}^{t}$ de $\mathrm{Ed}^{\mathrm{e}}$ heer Joannes Camphuijs voor haren wettigen Gouvern ${ }^{\mathrm{r}}$ Generael aan te nemen, te erkennen, respecteren en te gehoorsamen agtervolgens den eed, hier toe specialijk in Rade van India beraamt en op gestelt. Ge-

\footnotetext{
1 lees: volcke.
} 
geven in 't Casteel Batavia in 't Coninckrijk Jaccatra op 't Eijlt Groot Java den $7^{\text {en }}$ Augustij 1685 en was get. A. Hurdt, W. v. Outhoorn, Marten Pit, C. v. Quaalbergen ende J. v. Hoorn. Ter zijden stont 's Comp ${ }^{\text {cs }}$ groot zegel in rooden lacke gedruckt en daar onder: Ter ordonnantie van hooggemelte haar $\mathrm{Ed}^{\mathrm{e}}$ en getekent A. v. Riebeek Secrets.

Volgt nu den Algemeenen eedt van getrouwigheijt:

Wij alle dienaaren van de Generaale Nederlandse Oostindische Comp. soo van de commersie, militie, de zeevaart etc ${ }^{a}$ mitsgaders borgers en ingesetenen, bescheijden onder de gehoorsaamheijt en het gebiet van deselve Comp. geene uijt gesondert, beloven en sweeren dat wij de doorlugtige ho. mo. heeren Staten Generael van de vrije vereenigde Nederlanden als onse hoogste en souveraine overheijt, $\mathrm{Zijn}$ hoogheijt Willem .... en de Bewinthebberen van de Generale Nederlandse Oostindische Comp. mitsgaders ook den tegenwoordigen Gouv ${ }^{r}$ Generael over Oost Indien Joannes Camphuijs, gehouw en getrouw zullen zijn, en dat wij alle ordres, soo bij den artijculbrief ende ordonnantien, bij de voorschr. Bewinthebberen, ofte ook bij den voorschr. Gouv ${ }^{r}$ Generael en Raden van India alrede gemaakt, als die bij haarl. en alle andere onse Commandeurs en Bewinthebbers geduerende onsen dienst nog gem $^{\mathrm{kt}}$ zullen werden, naar ons uijtterste vermogen na te komen, ook in alles des voorschr. Gouvr Generael, zijne Raden mitsgaders onse overheden en mindere bevelhebbers ordres te volgen en zulx alles te doen, wat insonderheijt bij den articulbrief ten belange van de dienaars en bij de successive ordonnantien ten reguarde van de borgers en verdere onderdanen uijtgedruct staat.

Soo waarlijck helpe ons Godt almagtigh.

En vermits desen dagh ingevolge van 't gearresteerde in Rade van India op $8^{\text {en }} \mathrm{Julij}$ pass ${ }^{\circ}$ mede gedestineert was tot 't doen van den jaarlijxen optrek van de Nederlandsche schutterije deser stede, soo hoorde men dien 't halven mede al vroegh in de morgenstont de trommels roeren, om 't volcq ijder bij zijn compagnie te vergaderen, die dan ook alle, nevens de burger ruijterije deser stede (ten respecte van de te doene voorstellinge van zijn Ed $\mathrm{d}^{t} \mathrm{~d}^{\prime}$ heer Gouverneur Gener Joannes Camphuijs als nu buijten de ordinarie gewoonte mede op treckende) omtrent twaalf uijren 's middags, sig onder hare respective officieren en vaandels, op 't groote voorpleijn van dit Casteel, ten cier- 
lijcksten opgepronkt vervoegden, rangieerende hun aldaar aan de oostzijde van de wegh, met de front naar 't Casteel of wel regt tegen over het tonneel aan gemelte oostzijde volgens jaarlijx gebruijck van agteren digt aan de gragt opgeslagen, en met groen en bloemen verciert zijnde, ter welcker tijt zig ook aldaar in volle wapenen posteerden de expres daar toe geordonneerde compe militairen van 't Vierkant, de Utregtse poort, de Diestpoort, de Nieuwpoort, de Rotterdammerpoort, en die van de oost- en westzijdse buijtenforten, gerangieert als volgt:

De Comp. van de Diestpoort onder den Capitain Harman Egbertsz aan de regterzijde van het theater.

Dogh de Compagnie van de westzijdse buijtenforten, onder den Capitain Joan Maurits van Happel, nevens

d' Comp ${ }^{e}$ van de Utregtse poort, onder den Luijtenant Hans Ments, aan de linckerzijde van het theatrum.

d' Comp ${ }^{e}$ van 't Vierkant, onder den Capitain Joan Albert Sloot.

d' Comp' van de Rotterdammerpoort, onder den Capitain Thieleman van Eeuwijk.

d' Compe van de Nieuwpoort onder den Capitain Harmen Dirxe van der Poel.

En de Comp ${ }^{\text {en }}$ van de oostzijdse buijtenforten onder den Luijten ${ }^{t}$ Jacob d' Harder, alle vier aan de westzijde van de wegh die uijt het Casteel na de stad loopt, dog de twee eerstgen. van de 2 laatste afgesepareert om plaatse te laten voor d' Comp. militairen deses Casteels te voet; nevens aan de voorschr. Compe der oostzijdse buijtenforten quamen zigh mede te stellen de Chinesen deser stede, met vanen en wimpels, ten geleijde van den nieuw verkoren Capitain derselver Quekonko en d' Luijtenants Que Pauqua en Limkeko, welckers voorstellinge als nu mede stind te geschieden.

Dese Comp ${ }^{\text {en }}$ dan aldus gesteld zijnde, en de hier vooren geciteerde collegien en gequalificeerdens met hun vrouwen, kinderen en verder geselschap, item de Ternataanse princen Rotterdam, Hoeko en Niaman, met eenige andere grooten van Ternaten, vergeselschapt van hunne vrouwen; de Bantamse gesanten Keeij Aria Wieraxa; Keeij Aria Astra Wijaja; Keeij Aria Soeta Wisistra alias Vlamingh, de broeders des coninq van Pangiran Pourbaija en Radin Sake, met haar vrouwen als- 
mede de aanwesende gesanten van den oudsten Cheribonse prince, zig inmiddens binnen dit Casteel, en bij hooggem. Zijn Edt. vervoegd hebbende, soo begaf zig 's namiddags ten twee uijren na buijten: de comp. militairen deses Casteels te paart, opgevoert door den Sergeant Jan de Bart, en d' Comp. militairen te voet gecommandeerd door den Capitain Cornelis Nuijts, stellende zigh de ruijterije aan de linckersijde van 't tonneel naast aan de Compe van de Utregtse poort en de Comp ${ }^{e}$ te voet aan de westzijde van de wegh in de ledige gelatene plaats, tusschen de aldaar geposteerde Compagnien, als wanneer Zijn Ed $^{t} d^{\prime} h^{r}$ Gouv $^{r}$ Generael Joannes Camphuijs, verselt van de heeren Raden Anthonio Hurt, Willem van Outhoorn, Marten Pit, Cornelis van Quaalbergh en Joan van Hoorn (de heer Rijklof van Goens nog onpasselijk zijnde) item den E. Secretaris $M^{r}$ Abraham van Riebeek, met derselver resp ${ }^{e}$ huijsvrouwen mitsgaders een goet aantal gequalificeerde Juffrouwen en de hier vooren gementioneerde gequalificeerde ministers en inlandse grooten, alle op gisteren ten desen eijnde genodigt, zig mede uijt het Casteel, en op 't opgeregte theater vervoegde, alwaar hun om de voorstellinge van hooggedagte $\mathrm{Zijn} \mathrm{Ed}^{t}$ bij te woonen, en den generalen eedt te presteeren, ook lieten vinden, alle de inlandse hoofden en officieren der Chinesen, Mardijkers, Amboinesen, Bandanesen, Maleijers, Balijers, Macassaren, Boutonders, Bougisen, Javanen etc ${ }^{\mathrm{a}}$ als wanneer na een weijnig vertoevens, alle de Comp ${ }^{\text {en }}$ van 's Compes dienaren en burgeren op 't punt van 't rappier ${ }^{1}$ gesloten zijnde, de heer Directeur Generael Anthonio Hurt, als President van Schepenen, ende d' heer Ordinaris Raad Willem van Outhoorn, als Colonel der Borger schutterije, benevens den Secretaris van de hoge regeeringe van India $\mathrm{M}^{\mathrm{r}}$ Abraham van Riebeek, den baljuw Jacob Casembroot, de landdrosten Vincent van Mook en Laurens Pit en twee gecommitteerde leeden uijt 't eerw. Collegie van heeren schepenen, van het theater naar beneden traden en vervolgens van de regtervleugel af, voor de gerangieerde $\mathrm{Comp}^{\mathrm{en}}$ de oude afgaande officieren over haare bewesene diensten bedankten, en de nieuw verkoorene in ordre wederom voorstelde, gelijk mede geschiede omtrent de nieuw verkoorene officieren der Chinese ingesetenen deser stede, welkers Commissie aldus luijdende [is]: ${ }^{2}$

1 op de punt Saphier?

' zie bl. 34, onder $e$. 
Dit voorenstaande dan volbragt, en d' heeren Hurt en Outhoorn met hun geselschap weder op 't theatrum gekomen zijnde, soo wierd daarop aanstonts de akte van hooggedagte zijn Ed ${ }^{\text {ts }}$ aucthorisatie, hier bevorens geinsereert, door den Secret" d' E. Abraham van Riebeek alle den volcke voorgelesen, en door den heer Directeur Generael en eerste Raad Anthonio Hurd de gemeente afgevraagd, of zij ook bereijt waren den eed van getrouwigheijt en gehoorsaamheijt aan Zijn Ed ${ }^{t} d^{\prime}$ heer Gouv ${ }^{r}$ Generael Joannes Camphuijs daar op te presteren, twelk van een ijder met een ongemeene toejuijchinge beademd wesende, wierd daar op den generalen eed, ten dien eijnde in rade van India beraamd en hier vooren geinsereerd, door gem $^{\text {te }} \mathrm{E}$. Secretaris opgelesen, en door hooggemelte heer Directeur Gener ${ }^{1}$ Hurdt met 't opsteken der twee voorste vingeren en het voorseggen der woorden: Soo waarlijk helpe mij Godt almagtigh van een ijder in 't algemeen afgenomen en gevolgelijk door de gandsche vergaderinge agtervolgt, en zoodoende aan hooggemelte zijn $\mathrm{Ed}^{\mathrm{t}}$ gepresteert, naar 't welcke onder de gelukwenschingen aan $\mathrm{Zijn} \mathrm{Ed}^{t}$ door de heeren Raden, en verdere gequalificeerde ministers de ses regt over 't tooneel staande compagnien, soo dienaren, als borgeren, drie malen salvo schooten als wanneer zig de presente hooft officieren en verdere gequalificeerden van hun respe Compen af, en op 't theatrum gingen vervoegen om mede de felicitatie af te leggen, werdende inmiddels, soo van 't Casteel, de stadtspuncten, buijtenforten, als de rheede zoodanigh gecanonneerd, als volgt.

$$
\text { Van 't Casteel. }
$$

De punt den Diamant . . . . . . . . 7 schoten.

De punt van Paerel . . . . . . . . . . . $7, \mathrm{~d}^{\circ}$

De punt de Saphijr . . . . . . . . . . . . $7 \mathrm{~d}^{\circ}$

De punt de Robijn . . . . . . . . . . . $7 \mathrm{~d}^{\circ}$

Van des stadts punten.

Amsterdam . . . . . . . . . . . . . . $5 \mathrm{~d}^{0}$

Gelderlandt . . . . . . . . . . . . . . $5 \mathrm{~d}^{\circ}$

Hollandia . . . . . . . . . . . . . . $5 \mathrm{~d}^{\circ}$

Zeelandia . . . . . . . . . . . . . . $5 \mathrm{~d}^{7}$

Groeningen . . . . . . . . . . . . . $5 \mathrm{~d}^{\circ}$ 
$\mathrm{Pr}^{\mathrm{r}}$ transport . . 53 schoten.

Van de buijtenforten.

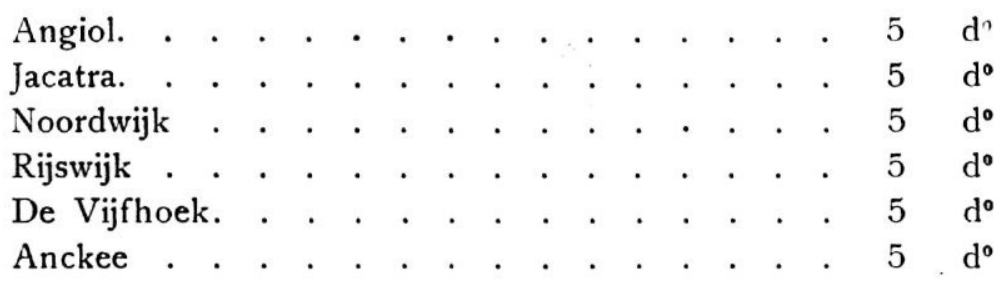

Van de veltschansen.

Tangerangh . . . . . . . . . . . . . . $5 \mathrm{~d}^{\circ}$

Maronda . . . . . . . . . . . . . . $5 \mathrm{~d}^{0}$

Bacassij . . . . . . . . . . . . . . . $5 \mathrm{~d}^{\circ}$

Van de scheepen op de Rheede.

d' Ridderschap van Holland . . . . . . . . $13 \mathrm{~d}^{\circ}$

Waterlandt . . . . . . . . . . . . . . $13 \mathrm{~d}^{\circ}$

d' Hollandse thuijn . . . . . . . . . . . . $13 \mathrm{~d}^{\circ}$

Macasser . . . . . . . . . . . . . . . $13 \mathrm{~d}^{0}$

Den Eenhoorn. . . . . . . . . . . . . $13 \mathrm{~d}^{\circ}$

De grote Visserije. . . . . . . . . . . . $13 \mathrm{~d}^{\circ}$

Twapen van Tertholen. . . . . . . . . . $11 \mathrm{~d}^{\circ}$

Odijck. . . . . . . . . . . . . . . . $11 \mathrm{~d}^{\circ}$

Eemlandt . . . . . . . . . . . . . . $11 \mathrm{~d}^{\circ}$

Stavenisse . . . . . . . . . . . . . . $11 \mathrm{~d}^{\circ}$

Waveren . . . . . . . . . . . . . . . $11 \mathrm{~d}^{\circ}$

Uijtmakende in 't geheel. . 231 schoten.

Onder dit canonneeren 't gequalificeerde geselschap zigh met het nuttigen van een treffelijk collation wat vervrolijkt hebbende, soo verliep den tijt tot omtrent half ses uijren, als wanneer een ijder der officieren en gequalificeerde schutteren zigh van 't theatrum en onder en voor zijn compagnien weder begaf, werdende als doen nogmaals van de ses compagnien, soo 's compagnies dienaren als borgeren, drie generale salvos gedaen, marchieerende kort daer aan de borger cavallarije digt voor bij het tonneel al schietende, en agter de andere compagnien om weder op zijn plaats, die vervolgens in maniere en rang, na den loop der jaarlijxe beurten, soodanig doen mede al afchargeerende voorbij het theater passeerden als hier onder werd aangewesen, en eerstelijk. 
1. Den Capitain Emanuel Bornezee.

Luijtenant Adriaan Piek.

Vaandrigh Govert van Hoorn.

Sergeanten.

Pieter van Dalen.

Jan George Thourman.

Joannes de Raadt.

Jan Jeppes.

Adriaan Nieuwlandt.

Adriaen Blanckert.

Jan Grootenhuijs $\mathrm{p}^{1} \mathrm{~d}^{0}$.

Sterk in 't geheel. . 234 coppen.

Bestaande uijt ongetrouwde pennisten en andere persoonen of suppoosten, hier in 't, Casteel en aan lant bescheijden, mitsgaders eenige ondercoopluijden, boekhouders, krankbesoekers etc ${ }^{a}$ van de hier ter rheede leggende schepen.

2. Den Borger Capitain David Disponteijn.

Luijtenant Hendrick Labeij.

Vaandrigh Hendrick Wacker.

Sergeanten.

David Schouten.

Gerrit van Goor.

Jonathan Resant.

Thomas Pedel.

Sterck in 't geheel . . $196 \mathrm{~d}^{\text {os }}$

Bestaande uijt de borgeren van de oostzijde binnen en buijten dese stadt.

3. Den Capitain Daniel Braams.

Luijtenant Dirck van Bleijswijk.

Vaandrigh Harmanus Busschof.

\section{Sergeanten.}

Pieter Duclasel.

Martinus Troeff.

Quilliam Stoppelaar.

Abraham Quevellerius.

Sterck in 't geheel . . $198 \mathrm{~d}^{\text {os }}$

Transporteere . . 628 coppen. 
Pr transport . . 628 coppen.

Bestaande uijt alle getrouwde pennisten en andere Compes dienaren hier aan lant bescheijden, en in de Stadt remoreerende.

4. Den Capitain Harmen Lodewijxe.

Luijtenant Willem Lucifer.

Vaandrigh Rijklof Pit.

\section{Sergeanten.}

Cornelis Condé.

Adams Smit.

Claas van der Straten.

Jan Doncker.

Dirck Nugteren.

Sterck in 't geheel . . 208 dos

Bestaande uijt het ambagts volcq en zeevarende, op de rheede, de werff, Onrust etc ${ }^{a}$ daar onder ook eenige lediggaande schippers etc ${ }^{a}$.

5. Den Capitain Jacob Does.

Luijtenant Francois Gadee.

Vaandrigh Carel Crab.

Sergeanten.

Joannes Fermes.

Joannes Ingelandt.

Frank Bernardus.

Joannes Melman.

Sterck in 't geheel . . $188 \mathrm{~d}^{\mathrm{s}}$

Bestaande uijt de borgeren van en aan de westsijde deser steede.

6. Den Capitain Adriaan Deman.

Luijtenant Christiaan Quickenburgh.

Vaandrigh Cornelis Anthonisz d' Linge.

Sergeanten.

Isaac Jansz.

Jan Gerritsz.

Transporteere . . 1024 coppen. 
Meijndert Ludolfsz.

Pr transport . . 1024 coppen.

Jan Christoffel Meijnhuijsen.

Evert Overhagen.

Barent Drijpon.

Jan Voogd Corp' der Adelborsten.

Sterck in 't geheel . . $175 \mathrm{~d}^{\text {ss }}$

Bestaande uijt de handwerckslieden en andere Compes suppoosten (als gesegt) in 't ambagts quartier bescheijden, waar op al kort volgde de borger cavallerije, treckende nogmaals de tent al schietende voorbij, en soo vervolgens stadwaart in, onder den Ridmeester Jan de Vlamingh, Luijtenant Jan Thijsz van Plesbagh, Cornet Hans Christoffel Haneman.

\section{Quar[tier]meesters.}

Carel Modet.

Godard Verdioen.

Sterck te samen koppen . . $52 \mathrm{~d}^{\text {os }}$

Zulcx uijt dit voorenstaande kan gesien worden, dat dese ses Compen Nederlandse schutters te voet met de borger cavallerije te samen sterk zijn geweest . . . . . . . . . . . . . 1251 koppen.

Dewelcke dan vervolgens van 't pleijn de stad in getrocken wesende, soo begaven zigh in gelijker voegen al schietende 't lusthuijs voorbij, en voorts ijder na zijn bescheijden post, de seven $\mathrm{Comp}^{\text {en }}$ militairen die ten respecte van $\mathrm{Zijn} \mathrm{Ed}^{\mathrm{ts}}$ voorstellinge waren gecompareerd te weten:

1. De Comp ${ }^{\circ}$ van de Utregtse poort, sterck . 106 coppen.

2. De Comp ${ }^{\circ}$ van de Westzijdse buijtenforten, sterk. . . . . . . . . . . . . . . . 68 dos

3. De Comp ${ }^{e}$ van de Diest poort, sterk . . . $174 \mathrm{~d}^{\text {os }}$

4. De Compe van 't Vierkant, sterck . . . . 112 d dos $^{\text {s }}$

5. De Compe van de Nieuwpoort, sterck . . $111 \mathrm{~d}^{\text {os }}$

6. De Comp ${ }^{e}$ van de Rotterdammerpoort, sterk 111 d $^{\text {os }}$

7. De Compe van de Oostzijdse buijtenforten, sterk . . . . . . . . . . . . . . $106 \mathrm{~d}^{\text {os }}$

Uijtmakende met den anderen . . 788 coppen. 
Behalve nogh de sterckte van de Comp deses Casteels zijnde . . . . . . . . . . . . . . . . 218 d $\mathrm{d}^{\text {os }}$

't getal van de ruijterije deses Casteels zijnde. $54 \mathrm{~d}^{\text {os }}$

En 't getal van Zijn Ed ${ }^{\text {ts }}$ oppassers zijnde . . $26 \mathrm{~d}^{\text {os }}$

Invoegen alle de op 't. pleijn verscheene militairen te samen uijtmaakten een getal van . . 1086 coppen.

En met de opgetrocken hebbende seven Compen Comp $^{\text {es }}$ dienaren en Borgeren sterck geweest zijnde (als hier vooren staat uijtgedruckt) . . . $1251 \mathrm{~d}^{\text {os }}$

Een considerabel aantal van Nederlandse koppen 2337

Dit afmarcheeren dan op dusdanige wijse tot 's avonts over seven uijren geduerd hebbende, soo begaf sigh den heer Gouverneur Generael Joannes Camphuijs met de heeren Raden van India en een groot gedeelte van 't genodigde Jufferschap en verdere vrunden etc ${ }^{\mathbf{a}}$ weder binnen dit Casteel, werdende van de Compagnien deses Casteels, soo te paart als te voet [geconduiseerd] komende insgelijx den Capitain Emanuel Bornezee met zijn Comp $^{\text {en }}$ uijt de stadt ten agt uijren weder binnen, treckende naar oudergewoonte 't groote pleijn over, des Generaels en alle der heeren Raden wooningen voorbij, in ordre en lustigh chargeerende, tot op 't agterpleijn voor desselven Capitains wooninge, alwaar doen ijder van 't opptrecken van desen dagh wierd ontslagen, om hun 's avonts op 't door de hooftofficieren aangestelde gastmaal wat te vervrolijken etc ${ }^{a}$ en hoedanigh dan dese zijn $E d^{\text {ts }}$ voorstellinge buijten op 't pleijn, en de Batavise eerste wapen vertooningh met genoegen $e n$ in vrolijkheijt is geeijndigt, sonder dat men (Gode zij dank) van eenigh notabel ongeluk heeft gehoord. ${ }^{1}$

Bij Res. 13 Juni 1691 wordt Kapitein Queeconko toegestaan een oesterbank te leggen voor den mond van de Antjolse rivier.

Hem werd 10 Juni 1695 ontslag verleend. Zie onder VII.

Bij Res. van 20 Juli 1696 wordt toegestaan ,het verzoek van den gewesen Cap $^{\mathrm{n}}$ der Chinese natie te deser stede Quekouwqua en nog seven sijner landslieden om haer metterwoon na Timor te mogen begeven".

${ }^{1}$ Op de Chineesche gemeente kan de voorstelling van hare drie Officieren niet veel indruk hebben gemaakt; ze had plaats zonder het gebruikelijke Chineesche vertoon en vormde slechts een onderdeel - evenals de jaarlijksche verwisseling van leden van ambtelijke Colleges en de optrek van militairen en schutterij - van de wijdluftige installatie van den Gouverneur-Generaal. 
Bij Res. 9 Oct. 1696 werd ,goedgevonden op het verzockschrift voor of van wegen den gewesen Capitain der Chinese natie Queconqua gepresenteert aan Heeren Schepenen deser stede en door Haar Eerwaarden aan de Regeering gerenvoyeert, Heeren Schepenen te qualificeren om op de gebruikelijke wijze, bij affictie van biljetten en klockegeluij te doen citeren alle degene die uijt krachte van schuld, borgtocht, koophandel, voogdij etc. eenige pretentien op den gemelten Qnekonqua zouden mogen sustineren of vermeenen te hebben, om dezelve binnen zekeren peremptoiren tijd te institueren".

Uit eene Res. van 2 Oct. 1703 blijkt dat „de oud Chinees Capitain Quekoenqua" toen nog in leven was.

\section{Limkeenqua.}

a. Res. 10 Juni 1695.

Wijders alsnu oock in agtinge genomen en gedelibereert sijnde over de menigvuldige ernstige versoeken van den $\mathrm{Cap}^{\mathrm{n}}$ der Chinese natie en Burgerije te deser stede Queconqua om van dien last ontslagen te mogen werden: so is, uijt consideratie van sijnen hogen ouderdom en toenemende swackheijt, verstaen hem sijn versoek te accorderen: en in sijn plaetse weder te laten optreden den eersten Luijten ${ }^{t}$ Limkeenqua, dewelke, met en benevens voorsz. Que-conqua, al zedert den jare 1685 den dienst van Luijtenant ten genoegen heeft bekleet. Ende wijle hierdoor de plaetse van eerste luijtenant nu mede komt open te vallen, soo is wijders verstaen daerin te surrogeren, den tweeden luijtenant der voorsz. natie Ongouko; mitsgaders in stede van dien weder tot twede luijten ${ }^{t}$ aen te stellen den Chinees Que-kiauko gew. sabandhar tot Samarangh.

b. Res. 21 Juni 1695.

$\mathrm{O} p$ het voordragen van den Heere Gouverneur Generael is tot vermijding van te groste confluentie van menschen binnen dit Casteel goetgevonden de voorstellinge van den geeligeerden $\mathrm{Cap}^{\mathrm{n}}$ der Chinese natie Limkeenqua, nevens den opgetreden eersten en nieuw verkoren tweede luijtenant Ongoucko en Quekiauko den $29^{\mathrm{e}}$ deser te laten geschieden op het Pleijn voor het Stadthuijs, door den balljuw David Dispontijn, nevens den landdrost $\mathrm{M}^{\mathrm{r}}$ Henrij de Bollan ende den E. Pieter Ketting, waernemende den dienst van Advocaet fiscael van Indien, mitsgaders 
twee gecommitteerde leden uijt de respective bancken van Justitie deser stede, sullende onse Commissie voor den gem. Capn Limkeenqua eerst in de nederduijtsche tale door den gesworen clercq van Heeren Schepenen Joannes Maurus en vervolgens door den Chinese schrijver Gou-houlan in hare sprake den volke werden voorgelesen.

\section{c. Batavia den 29 Junij A 1695.}

Willem van Outhoorn, Gouverneur Generael mitsgaders de Raden over den staet van de generale Nederlandse g'octrojeerde Oostindische Comp ${ }^{e}$ in India, allen dengenen die desen sullen sien ofte horen lesen Saluijt, doen te weten:

Alsoo den Capitain der Chinese natie te deser stede Batavia Que Conqua op sijne iterative instantien en versoeken en uijt consideratie van sijne lange continuatie en presenten hogen ouderdom van dat ampt ontslagen is, en het dierhalven vereijscht dat weder een ander bequaam en wacker man tot Capiteijn en hooft over gem. natie wert gestelt, soo is 't dat in Rade van India daer over gedelibereert, en gelet sijnde op de bequaamheijt en goede qualiteijten van den outsten off eerste luijtenant van deselve natie Limkinqua, dewelke zedert den jaere 1685, dat nevens den Capitein Que Conqua tot die qualiteijt aangestelt is, hem ten genoegen daerin heeft gedragen, vervolgens verstaen en goetgevonden is den gem. Limkeenqua aan te stellen en te laten optreden tot Capiteijn, opperhooft en voorsprake der meergem. Chinese natie en ingesetenen te deser stede, gelijck wij hem daertoe ook aanstellen, nomineren en authoriseren bij desen, om met ende benevens den gem. tweede luijtenant Ongouko, die wij insgelijx weder tot eerste luijtenant hebben goetgevonden te laten optreden, mitsgaders den nieuw verkozen tweede luijtenant Quekiauko ${ }^{1}$, de saken van gem. ingesetenen na behoren en onse orders te manieeren, met even soodanigen magt ende authoriteijt als sijnen predecesseur Quekonqua heeft gehad, namentlijck omme met communicatie sijner voorseijde twee luijtenants ofte mindere officieren alle kleijne voorvallende saeken onder de Chinese burgerije alhier uijt onsen name af te doen ende te beslegten, dog de groote of andersints dubieuse te renvoijeren daer 't behoord, mitsgaders verders alles te doen, wat een goet, vroom en wacker capiteijn, opper-

${ }^{1}$ Res. 10 Juni 1695.

Dl. 78. 
hooft en voorsprake toestaet en betaemt, ordonneren ende bevelen derhalven aan alle hoge en lage officieren en specialijk die van den E. geregte deser stede, den voorsz. Limkeenqua daer voor aan te nemen ende te erkennen, ook in alle saeken sijn officie rakende behoorlijck te maintineren ende voor te staen, vorders aan alle Chinese ingesetenen deser stede, soo die althans hier resideren als die namaels nog soude mogen komen, denselven in sijn voorsz. officie alle behoorlijke gehoorsaemheijt, eere, hulpe ende bijstand toe te brengen ende te bewijsen, alsoo wij sulx ten dienste van de generale Comp. en het gerief en welstand der gemelte Chinese burgerije alhier zodanig bevinden te behoren.

Gegeven in 't Casteel Batavia op 't Eijlant Groot Java in 't Coninkrijk Jaccatra desen 29 Junij $\mathrm{A}^{0}$ 1695. (was getekt) W. van Outhoorn. Ter zijden stont 's Comps zegel in roden lacke gedrukt (en daeronder) Ter ordonnantie van hooggem. haer Ed $^{\text {le }}$ (was getekent) Christoffel van Swoll. E. clerq.»

Limkeeko alias Jacob Limkeenko alias Jacob, was Boedelmeester in 1683 en 1684 .

Bij Res. 4 Dec. 1699 werd „verstaan aan den Cap" der Chinesen Limkeenqua op desselfs schriftelijk versoeck te licentieren het opregten van twee suijkermolens op desselfs land gelegen ongeveer ses mijlen opwaerts aan de groote Rivier, genaamt Comirij".

In Res. 8 April 1749 wordt van Limoensaaij gezegd dat hij de aangenomen zoon en erfgenaam was van Limkeenqua, den $a^{\circ} 1706$ of wat later in China overleden Kapitein. Deze overleed echter 4 April 1707 te Batavia. (Zie VIIIa).

\section{Tambocco.}

a. Res. 11 April 1707 .

De heeren bij den anderen gekomen zijnde ten principalen om de lectura van het rapport van den Commandeur $\mathrm{Cnol}$ en Capitain van der Horst wegens derzelven verrigtinge ten hove bij den Sousouhoenang Pakoebowano te vervolgen, heeft den heere Gouverneur Generaal, alvorens deselve weder bijderhand te nemen, in omvrage gelegt of men tot de verkiesinge van een Capitain over de Chineesen alhier, in steede van den op 4 deser overledene Limkeenqua, heeden dan wel nog eenige dagen en tot de volbragte begravenis van den overledene wagten soude, 
waarop het advijs van de $\mathrm{H}^{\mathrm{r}}$ van Swoll opgehaelt zijnde, is nodig geagt als nu tot de verkiesinge te treeden ende vervolgens eenparigh goedgevonden daartoe aan te stellen den oudste luijtenant dier natie Tambocco, aan denwelke ook met eenen om hem te meer ten goede tot de belangen van d' E. Comp ende die der gemeente te animeeren, goedgevonden werd bij taxatie in eijgendom te geven het stuk lands hem den $20^{\text {n }}$ October 1705 aan de oostzijde der Tangerangse rivier tot het opregten van suijkermolens vergunt en door hem reets daer toe geprepareert, en werden heeren Heemraden gequalificeert hetselve land na ingenomen advijs van den gesw[oren] landmeeter Bartel van der Valk te taxeeren.${ }^{1}$

\section{b. Dagreg. 3 Junij $1707 .^{2}$}

Heden den vastgestelden dag zijnde, om ingevolge van het geresolveerde in Rade van India op den $11^{\mathrm{e}}$ April passado, den nieuw aangestelden Capitain der Chineese natie Tambocqua voor te stellen, soo quam denselven g'accompagneerd van sijne Lieutenants Quehoenko en Lionko omtrent ten 9 uuren ten huijse van sijn Edelheijd den Heere Gouverneur Generaal, gelijk mede den Bailliuw Joannes Ens, den Landdrost Michiel Ram, den Advocaat Fiscaal van India mr. Cornelis van Berendregt en twee gecommitteerde Leden uijt beijde de collegien van Justitie, van waar, nadat de Pargamente Commissie door welgemelte sijn Edelheijd aan de Leden uijt den agtbaren Raad van Justitie was overgegeven, gingen vervolgens te samen tot buijten de Landpoort deses Casteels, alwaar een groot getal Chineesen (die met gomme slag daags te vooren waren gewaarschouwd, om voormelde voorstellinge bij te woonen) ten meerendeele voorsien met vlaggetjes op hare maniere gemaakt haar stonden op te wagten, en wierden vervolgens tot aan 't Stad-huijs door deselve van daar geconduiseerd; werdende voormelde commissie in 't Nederduijts geleesen door den Secretaris van Heeren Scheepen François Verboom, ende in de Chineese tale door den schrijver dier natie, en quamen vervolgens rapport doen van hare verrigtinge aan opgemelte sijn Edelheijd. Luijdende meergemelte Commissie in 't Nederduijts aldus:

${ }^{1}$ Blijkens extract notulen Heemraden van 21 April 1707 was de waarde van dit stuk land getaxeerd op $350 \mathrm{rds}$. (Res. $6 \mathrm{Mei}$. 1707).

2 Landsarchief. 
Joan van Hoorn, Gouverneur Generael, mitsgaders de Raden over den Staet van de generale Nederlandsche geoctroijeerde Oost Indise Compagnie in India, allen dengenen die desen zullen sien ofte horen lesen, Salut, doen te weten:

Alsoo den Capitein der Chinese natie te deser stede Batavia Limkeenqua in de maend April pass ${ }^{\circ}$ is komen te overlijden en het dierhalven vereijst, dat weder een ander bequaem en wacker man tot Capitein en hooft over gem ${ }^{\mathrm{e}}$ Natie werde gestelt, soo ist: dat in Rade van India den $11^{\mathrm{e}}$ April jongstleden, daer over gedelibereerd en gelet zijnde op de bequaemheijt en goede qualiteijten van den oudsten of eersten luijtenant van deselve natie Tambocqua, dewelke zedert den jare 1692, dat tot die qualiteijt aengesteld is, hem ten genoegen daerin heeft gedragen, vervolgens verstaen en goet gevonden is, den gem $^{e}$ Tambocqua aen te stellen en te laten optreden tot Capitein, opperhooft en voorsprake der gem $^{\mathrm{e}}$ Chinese natie en ingesetenen te deser steede, gelijk wij hem daertoe ook aenstellen, nomineren en authoriseren bij desen, om met en benevens de Luijtenants Quehoenko en Liejonko de saken van gem $^{\mathrm{e}}$ ingesetenen na behoren en onse ordres te manieeren met even sodanigen magt en authoriteijt als zijnen predecesseur Limkeenqua heeft gehad, namentlijck omme met communicatie zijner luijtenants, alle kleijne voorvallende saken onder de Chinese Burgerije alhier uijt onsen name af te doen ende te beslegten, dog de grote of andersints dubieuse te renvoijeren daer 't behoort, mitsgaders verder alles te doen, wat een goet, vroom en wacker capitein, opperhooft en voorsprake toestaet ende betaemt. Ordonneren en bevelen derhalven aen alle hoge en lage officieren en specialijk die van de E' geregte deser steede den voorsz. Tambocqua daer voor aen te nemen ende te erkennen, oock in alle zaken zijn officie rakende, behoorlijck te maintineren ende voor te staen. Verders aen alle Chinese ingezetenen deser stede, soo die althans hier resideren als die namaels nog zoude mogen komen, denselven in zijn voorsz. officie alle behoorlijcke gehoorsaemheijt, eere, hulpe ende bijstand toe te brengen ende te bewijsen, alsoo wij zulx ten dienste van de generaele Compagnie en het gerief en welstant der gem $^{\mathrm{e}}$ Chinese burgerije alhier sodanig bevinden te behoren.

Gegeven in 't Casteel Batavia op 't eijlant Groot Java in

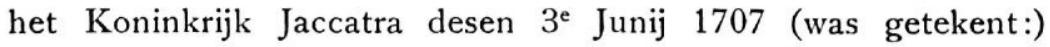
$\mathrm{J}^{\mathrm{n}}$. van Hoorn (ter zijde stond 's Comps zegel in rode lacque 
gedrukt, en daer onder) ter ord ${ }^{\mathrm{e}}$ van hooggem. haer Ed. (was getekent) I. Garsin, Secretaris».

c. Res. 21 Februari 1719.

Voorts is op het schriftelijck gedaan versoek van den Capitain der Chineesen alhier Tamboqua, tans in siekte vervallen zijnde, verstaan hem te qualificeren bij testamente onder sijne familie tot een begraafplaats te designeeren, en bij sterfgeval na te laten sonder dat hetselve sal mogen verkogt of op eenigerhande wijse veralieneerd werden, seker stukje lands hetwelk hij van eenen Johannes Barkus volgens coopbrief van den $8^{\text {n }}$ Junij 1718 gekogt, en met dat oogmerk reeds daartoe geprepareerd heeft, onvermindert de kragt onser resolutie van den $29^{\text {n }}$ Maij 1705 tegens het beswaren van vaste goederen door speciale fideicommissen gedecreteerd.

Als opvolger van den overleden geschoren Chinees Kiay aria Martanata, werd hij bij Res. 2 Aug. 1697 aangesteld tot „Sabandhar en hooft van die van sijne natie tot Serribon".

Bij Res. van 16 Juni 1702 werd hij, naltans Capitain over die natie tot Chirribon" benoemd tot Luitenant te Batavia.

Bij Res. van 15 Juni 1703 werd ,Tamboko tweede luijtenant van die natie alhier, sijnde met eenen daarvan Capitain tot Cheribon" op zijn verzoek uit den laatsten dienst ontslagen en hem vergund daarvan transport te doen aan den Chinees Tansjauko.

Hij overleed 23 Febr. 1719 (Zie IX).

Bij Res. van 28 Dec. 1725 werd „Tantionqua, soone van den gestorven Capitain Tanboqua" benoemd tot Luitenant.

„Tam" is eene verschrijving voor Tan, den veel voorkomenden geslachtsnaam.

\section{Quebauqua.}

Res. 3 Maart 1719.

Ook na gedane omvrage nodig geoordeeld zijnde te treden tot de verkiesing van een ander Capitain over de Chinesen hier ter stede, in plaatse van den op $23 \mathrm{Feb}^{\mathrm{rij}}$ passado overleden Capitain Tamboqua, soo is ten aansien de twee lieutenants over die natie Lijongqua en Ho Lie Enqua reeds bejaard en tans van het vereijste vigeur niet meer en zijn, eenparig goedgevonden en verstaan tot Capitain aan te stellen den oud boedelmeester der Chineesen Quebauqua, mitsgaders de voorstelling van denselven in voormelte qualiteijt ter gelegenertijd te laten geschieden na voorgaande usantie te vinden zijnde en genoteerd op den $3^{\text {n }}$ Junij 1707 bij het dagregister deses Casteels. 
In het Emoy-dialekt heet deze geslachtsnaam: Keeh. Het schriftteeken daarvoor is 萛 dat wordt uitgesproken ,kok" (Zie Medhurst, Hok-kian Dictionary, bl. 402 b).

De persoonsnaam zal zijn geweest 晶 bau (a. w. bl. 13) waarvoor Medhurst bij de vertaling van het handschrift der "Chronologische Geschiedenis" zal hebben gevonden of gelezen 星 gang. (a. w. bl. 182a). Zoo wordt het verklaarbaar dat Medhurst dezen Kapitein Kok Gang noemde in plaats van Keeh Bau.

$\mathrm{Hij}$ was Boedelmeester in $1707,1708,1711,1712,1714$ en 1715 en overleed vermoedelijk op een van de eerste dagen der maand Januari 1733 (Zie $\mathrm{Xa}$ ) en werd eerst na 2 Juni 1733 begraven. (Zie Xb).

Zijne voorstelling had plaats op 11 Juli 1719. (Zie Xa slot).

„Door den Capitain der Chineesen Que Bauqua bij requeste permissie versogt werdende om seecker stukje land gelegen omtrent een uur gaans buijten dese stad in het Westerveld, het $11^{\mathrm{e}}$ deel van het blok $\mathrm{P}$, aan hem door den inlands borger Frederik Nicolaasz gedonnateerd, te approprieeren tot eene begraafplaats voor hem en sijne nakomelingen onder conditie dat hetselve nooijt sal mogen werden verkogt ofte veraliencerd, is verstaan hetselve te accordeeren en gedagte strookje lands tot nader dispositie deser regering te beswaren met een fidei commissairen band waarvan den geregte sal werden kennisse gegeven door extract van desen". (Res. 4 Jan. 1726).

\section{Que Tjoenqua.}

a. Res. 6 Januari 1733 .

Door het afsterven van Que Bauqua eenige dagen geleden, vacant geworden zijnde het ampt van Capitain over de Chineese natie waartoe denselven bij resolutie van den $3^{\text {n }}$ Maart 1719 was aangesteld, en hetwelke hij sedert opgem. tijd sooveel bekend is ook met alle candeur tot zijn dood toe heeft gefungeerd, soo is op de propositie van den heere Gouverneur Generaal verstaan, soo om dese als andere redenen diendwegen bij zijn Ed mondeling voorgebragt ditmaal weder als bij zijne aanstellinge het oog soo seer niet te laten vallen op een der lieutenants, maar integendeel reflexie te slaan op de zoon van den overleden, zijnde den oud boedelmeester Que Tsoenqua, die bij het leven van voorm. zijn vader al veel tijds in het waarnemen van gem. bediening denselven behulpsaam is geweest, en dienvolgende daartoe de vereijschte kennisse en bequaamheijd schijnt te zullen hebben, mitsgaders boven des ook in goeden reuk is soo bij de Europeese als zijne eijgene natie, en soo veel men weet sig altoos stil en zedig gedragen heeft, en dienvolgende gem. Que Tsoenqua 
daartoe te eligeeren en aan te stellen, om ter bequamer gelegentheijd naar de keuse van den heere Gouverneur Generaal daarinne publicq g'installeerd en bevestigd te werden met het ceremonieel bij sulke plegtigheden in gebruijk en nog laast voor opgem. Que Bauqua, te vinden zijnde bij het dagregister deses Casteels onder den $11^{\mathrm{n}}$ Julij des gem. jaars 1719 .

\section{b. Res. 2 Juni 1733.}

Wijders is op de vrage van den welgem. heere GouverneurGeneraal of den ter resolutie van den $3^{\text {n } 1}$ Januarij deses jaars aangestelden Capitain over de Chineesche natie te deser stede in name Que Tsoenko volgens het voorige gebruijk zoude voorgesteld worden, verstaan zulx na vereijsch van zaken te laten voortgang nemen en ten dien eijnde te doen opvolgen de uijtterlijkheden en ceremonien die jongst ontrent de voorstellinge van zijnen antecesseur en overleden vader Que Bauqua na 't aangeteekende bij het Dagregister deses Casteels onder den $11^{\mathrm{n}} \mathrm{Julij}$ des jaars 1722 hebben plaats gehad. ${ }^{2}$

Dog daarentegen is verstaan te ontseggen het versoek van denselven Que Tjoenko teneijnde zijn voorm. vader met een Comp. militairen uijt het Europeese guarnisoen te dezer plaatse te mogen begraven, alschoon zulx in voorigen tijd schijnt in gebruijk te zijn geweest en daarvan ook een voorbeeld in den jare 1684 ontrent eenen Capitain Wanjok gevonden werd, ${ }^{3}$ nadien hetselve egter niet weer gepractiseert en overzulx al genoegsaam in ongebruijk geraakt is, buijten en behalven dat ook in 't geheel seer oneijgen schijnt te wesen, ter zake den Capitain der Chineesen niet soo seer voor een militair als wel voor een politicq hoofd zijner natie kan aangemerkt werden en ook bij zijn leven geen de minste eerbewijsinge van de militie komt te genieten.

c. Batavia, den $27^{\mathrm{n}}$ Julij 1733 .

$M^{r}$ Dirk van Cloon, Gouverneur Generael, mitsgaders de Raden over den Staat van de generale Nederlandse Oost Indische Compagnie in India, allen dengeenen die desen sien ofte hooren leesen, Salut, doen te weten :

\footnotetext{
1 lees: 6 $6^{\text {en }}$ (zie bl. 54).

2 lees: 1719 (zie onder $a$ ).

3 zie: bl. 31 .
} 
Alzoo den Capitain der Chineese natie te deser stede Batavia Que Bauqua met het uijteijnde van het jongst verwekene jaar 1732 is komen te overlijden en het derhalven vereijscht dat weder een ander bequaam en wacker man tot Capitain en hoofd over gemelde natie werde gestelt, Soo ist, dat in Rade van India op den $3^{e}$ der voorledene maand Januarij daarover gedelibereerd, en gelet zijnde op de bequaamheijd en goede qualiteiten van des overledens zoon den oud boedelmeester van deselve natie Que tSoenqua, vervolgens verstaan en goedgevonden is den gemelden Que tSoenqua te verkiesen en aan te stellen tot Capitain, opperhoofd en voorsprake der meergem ${ }^{\mathrm{e}}$ Chinese natie en ingesetenen te deser stede, gelijk wij hem daartoe ook aanstellen, nomineeren en authoriseeren bij desen, om met en benevens de ses Lieutenants dier natie in name Limtsoenko, Limsomko, Tantiongko, I Oseengkong, Nihoekong en Li Hooko, de saken van gem. ingesetenen na behoren en onse ordres te manieeren met even sodanige magt en authoriteit als opgemelde zijn vader en predecesseur Que Bauqua heefd gehad. Namendlijk omme med communicatie zijner lieutenants alle kleijne voorvallende zaken onder de Chinese burgerije alhier uijt onsen name af te doen ende te beslegten, dog de groote of andersints dubieuse, te renvoijeeren daar het behoord, Mitsgaders alles te doen wat een vroom, goed en wacker Capitain, opperhoofd en voorspraake toestaat en betaamd, Ordonneeren en beveelen derhalven aan alle hooge en lage officieren, en specialijk die van den E. geregte deser stede, den voorz. Que tSoenqua daarvoor aan te nemen ende te erkennen, ook in alle zaken zijn officie rakende behoorlijk te maintineeren ende voor te staan, verders aan alle Chinese ingesetenen deser stede, soo die althans hier woonagtig zijn, als die namaals nogh zouden mogen komen, denselven in zijn voorsz. officie alle behoorlijke gehoorsaamheijd, eere, hulpe ende bijstand toe te brengen, mede te bewijsen, alzoo wij zulx ten dienste van de generale Compe en het gerieff en welstand der gem. Chineese burgerije alhier sodanig bevinden te behoren.

Gegeven in 't Casteel Batavia op 't eijland Groot Java in 't Coningrijk Jaccatra desen $27^{\text {n }}$ Julij $A^{0}$ 1733, (getek ${ }^{t}$ ) D. van Cloon, (ter zijde stond) 's Comp's zegul gedruckt in rooden lacque (en daar onder) Ter ordonnantie van hooggem. haar Edelens (getekent:) G. Bogaert, Secrs. 
Hij was Boedelmeester in 1724 en 1725.

Kapitein Que Tsoenqua en Luitenant Khouw Tjenko hadden arakbranderijen even buiten de Diestpoort. (Res. 4 Juli 1738).

Maurits van Aarden, Secretaris van Schepenen, was sequester in den insolventen boedel van den overleden Kapitein Que Tsoenqua (Res. a. v.). (Vgl. Res. 4 Dec. 1739).

\section{Nihoekong.}

Res. 11 September 1736.

Voorts op de propositie van den heere Gouverneur Generaal gedelibereerd zijnde over de verkiesinge van een Capitain over de Chineese natie te deser steede in plaatse van Que Tsoenko die over eenigen tijd overleden is, so wiert uijt aanmerckinge dat denselve buijten de verdere vereijscht werdende qualiteijten ook wel dient te weesen een man van middelen, na overweginge van het nodige goetgevonden en verstaan daartoe uijt degeene die hun persoon en dienst hebben aangeboden te verkiesen en aan te stellen den luijtenant Nihoekong.

Hij was de oudste zoon van Luitenant Nilocko uit diens huwelijk met Tan Teengnio en, na in 1730 en 1731 Boedelmeester te zijn geweest, volgde hij zijn overleden vader op als Luitenant. (Res. 6 Febr. 1733. Vgl. over deze benoeming Bijdr. Kon. Inst. Deel 73 (1917), bl. 190).

Hij heet in $\mathbf{1 7 4 0}$ dertig jaren oud te zijn geweest en was getrouwd met Lim Oatnio, dochter van Luitenant Limtsoenko, bij wie hij acht kinderen had verwekt, van wie in 1740 nog drie in leven waren, onder wie ten minste één zoon was. Den $10^{\text {on }}$ October 1740 werd hij in hechtenis gesteld op de punt de Robijn; den $18^{\text {en }}$ October werd besloten hem te laten overbrengen „in 's Compagnie's boeijen"; den 21en Januari 1741 werd hij „tot nader en scherper examen" gebracht; bij vonnis van den Raad van Justitie van den $6^{\text {en }}$ Augustus 1743 werd hij veroordeeld tot verbanning voor 25 achtereenvolgende jaren, welk vonnis in revisie werd bekrachtigd (Sententie van den 18en Mei 1744). Ingevolge dit gewijsde, bepaalde de Regeering dat hij naar Ceijlon zou worden "verzonden" (Res. $22 \mathrm{Mei}$ 1744) maar op zijn verzoek werd hij naar Amboina gerelegeerd (Res. 16 Juni 1744), waar hij den $25^{\text {"n }}$ Dec. 1746 overleed. Zie over hem „Ni Hoekong" in Bijdr. Kon. Inst. Deel 74 (1918) bl. 447.

\section{Lim Beengko.}

\section{a. Res. 25 Juni 1743.}

Voorts door den heer Gouverneur Generaal de vergaderinge te kennen gegeven zijnde de verlegentheijd waarinne zijn Edelheijd dagelijks quam te vallen, wanneer iets omtrent de thans 
weeder in een ruijm getal alhier gepermitteerde Chineesen wilde ordonneeren, aangesien deselve nog sonder eenige hoofden off opsigters zijn, waerdoor dan voornamentlijk in deesen tijd dat men de nieuwelingen, altoos geneegen om clandestin hier in de colonie te verblijven, door bekkenslag en waarschouwing mitsgaders goede toesigt van gem. hare hoofden als dwingen moeten om weder met de jonken te vertrecken, weederom veele desorders soude kunnen ontstaan, vermeenende zijn Edelheijt dat ingevalle men Chineese in deese Colonie admitteeren wil, waar van de noodsakelijkheijt 't sedert $A^{\circ} 1740$ maar meer dan te veel is gebleeken, men ook teffens vaststellen moet dat deselve onder haare eijgene hoofden moeten weesen soo de huijsselijke bestieringe onder die menschen sal gaan op eene gereguleerde en voor haar gemackelijken voet. Soo heeft de Vergaderinge sig met de voorsz. consideratien geconformeert en is dienvolgende goedgevonden bij provisie een captaijn en twee luijtenants over de Chineese Natie weder aan te stellen ende verkiesinge der daartoe bequaamste personen aan den heer Gouverneur Generaal gedefereert te laten.

\section{b. Res. 28 Juni 1743.}

Voorts door Welgem. Sijn Edelheijt de regeering te kennen gegeven sijnde desselfs gedagten wel te [hebben] laten gaan tot het benoemen van drie der bequaamste Chineesen tot Capitain en luijtenants over die van hare natie, hetwelk de vergadering ter jongste sessie wel aan Sijn Edelheijt hadden willen gedefereert laten dog dat den Chinees Lim Souko die bij Sijn Edelheijd als een van de opregste en bemindste onder die [van] zijne natie tot Capitain int oog genomen was daar voor hadde bedankt en versogt van die last bevrijd te weesen, mitsgaders dat de overige soo wel niet bij Sijn Edelheijt waren bekent als mogelijk bij de heeren leeden, onder eene vrage wien haar Ed. wel vermeende[n] daartoe de beste te zijn, soo is goedgevonden en verstaan den Chinees Lim Beengko tot Capitain ende meede [de] Chineesen Oeij Tsomko en Tan Iko tot luijtenants over die van hare natie aan te stellen.

c. Res. 6 Augustus 1743 .

Bij dese gelegentheijt is ook op de vrage van den heere Gouverneur Generaal verstaan den jongst aangestelden Capitain 
over de Chineese natie Lim Beengko, na vorige usantie dog met soo weijnig ceremonie als mogelijk, publicquelijk te doen voorstellen, en denselven met de twee luijtenants, nevens degeene die tot hare functie relatie hebben, met er woon binnen dese stadt te admitteeren, onverminderd nogthans het besluijt ten dien reguarde op den $11^{\mathrm{n}}$ November 1740 genomen, dat in sijn geheel gelaten word ten opsigte van alle andere Chineesen, nadien het admitteeren van hare hoofden ter woon binnen dese stadt voor noodsakelijk en inevitabel moet werden aangesien so de neering en handteering weder herleven en voortgeset werden sal sonder interrumptie mitsgaders ook geen infractie geven kan aan dat besluijt van eenige speculatie.

\section{d. Dagreg. 19 Augustus $1743 .^{1}$}

Des morgens om 9 uuren wierd den geeligeert $\operatorname{Cap}^{\mathrm{n}}$ van de in dese colonie gereadmitteerde Chineesen Lim Beengko, volgens haer Ed. besluijt van den 6 Hujus, naar het Formulier van de g' expedieerde commissie sub 24 der voorl. maand dog sonder eenige ceremonien, ten overstaan van de gecommitteerdens uijt de beijde collegien van Justitie en den advocaat fiscaal, item den ballieuw en landdrost nevens de secretarissen van voorm. collegien van de puije van het stadhuijs in 't openbaer voorgestelt: Siet hiervan met seclusie der ceremonien het Batavia's Dagregister d' $\mathrm{a}^{\circ} 1707$ dato $3 \mathrm{Junij}$, alwaar een gelijkstandig voorbeelt gevonden word; sijnde de acte van authorisatie bij het afgaande Batavias resort van den Jaere 1743 te vinden.

Bij Res. 11 Sept. 1742 werd toegestaan het verzoek „van den thans hier in loco sijnde Chineesen Sabandhaar tot Bantam Lim Beengko . . . een huis te mogen huuren en occupeeren in de Zuijder Voorstad alhier, tot het voortsetten van zijnen handel".

"Lim Beengko, als pro dato sonder eenige opspraak alhier gezeeten sijnde geweest, te permitteeren sig weeder te deezer plaatze te mogen ter neder zetten en uijt dien hoofde hem soodanig een permissiebriefje te laten afgeeven." (Res. 20 Nov. 1742). Deze briefjes waren, na eene volkstelling onder de Raden Crul en van Aarden gehouden, in de plaats gekomen van de briefjes van pardon.

$\mathrm{Hij}_{\mathrm{ij}}$ verzocht "te worden geprivilegieert tot het koken en verkopen van madat" hetgeen bij Placaat van 28 Dec. 1729 en Res. 6 Sept. 1729 was verboden. Voor één jaar werd dit privilegie toen aan hem verpacht (Res. 13 Dec. en 16 Dec. 1746); bij Res. 13 April 1747 werd het ingetrokken.

\footnotetext{
1 Landsarchief.
} 
Hij is noch Boedelmeester noch Luitenant geweest en overleed vóór 17 Maart 1747; zijn woonhuis werd toen aangekocht om te dienen als ambtswoning voor zijne opvolgers. (Res. 25 April en 9 Mei 1747).

Aan zijne weduwe Tan Tjenio en haar zoon Lim Thoenko (Boedelmeester in 1747 en 1748) werden bij Res. 17 Maart 1750 brieven van atterminatie of respijt verleend voor den tijd van vijf jaren. Bij Res. 22 Juni 1753 werden Weesmeesteren gequalificeert hun uitstel te geven van de betaling eener schuld aan den boedel van G. G. van Imhoff.

\section{Oeij Tsomko.}

\section{a. Res. 21 April 1747.}

Mits het overleijden deser dagen van den Capitain der Chineesen alhier Lim Beengkongh door den heer Gouverneur Generaal nopens het vervullen van dat ampt gesproken, dogh voor af de heeren leeden in overweginge gegeven zijnde, of hun Edelens niet evenals welgem. zijn Edelheijt vermeende nodig te weesen dat door diegene, dewelke daartoe althans mogte werden verkoren, so wel als door zijne successeuren in 't vervolg voor schepenen te deser steede wierde afgelegt, na de wijse van die natie, den eed van purge die voor de g'advanceerde en in eenige ampten gesteld werdende dienaren ter sessie van den $4^{\mathrm{n}}$ Junij 1743 is g'arresteerd, zo wierd goedgevonden sulx na den voorstel van welgem. zijn Edelheijt te laten effectueeren, en voorts verstaan tot Capitain der Chineesen alhier te verkiesen en aan te stellen den oudsten lieutenant dier natie Oeij Tsomko, en naeder tot lieutenant, den boedelmeester Tsou Tsoenseengh.

\section{b. Res. 5 Mei 1747.}

Den jongst aangestelde Capitain der Chineesen Oeij Tsomko, ingevolge het besluijt deser tafel van den 21 April jongstleeden bij schepenen te deser stede hebbende afgelegt den eed van purge wegens de verkrijging van dat ampt, blijkens een ingekomen extract uijt de resol. van haar Eerw. van den $3^{\text {n }}$ deser, zo wierd verstaan hetzelve bij desen te noteeren, en den gem. Capitain aan die van zijne natie te laten voorstellen na de gebruijken van den vorigen tijdt, te vinden bij de Dagregisters deses Casteels van den jare 1707 en 1719 omtrent Tamboqua en Quebauqua, dewijl de schikking omtrent die natie thans weder nabij herstelt is op den alouden voet en dus de bijsondere reflexie daarop gevallen bij de eerste weder aanstelling van 
een hooft over deselve na het aangetekende bij resolutie van den $6^{\mathrm{n}}$ Augustus des jaars 1743 althans so seer niet meer vereijscht werden.

c. Batavia, den $6^{\mathrm{e}} \mathrm{Junij} \mathrm{A}^{\circ} 1747$.

Gustaaf Willem Baron van Imhoff, Gouverneur Generaal, mitsgaders de Raden wegens den staat der Vereenigde Nederlanden en de generale g'octroijeerde Oostindische Comp. allen dengeenen die desen sullen sien ofte horen leesen, Salut, doen te weeten:

Alsoo den capitain der Chineesche natie alhier Lim Beengkongh, nu onlangs is komen te overlijden, en het derhalven vereijscht dat weder een ander bequaam en wacker man tot Capitein en hoofd over gemelde natie werde gesteld, soo is 't dat in Rade van India op den $21^{\mathrm{n}}$ der jongst gepasseerde maand April, daarover gedelibereert en gelet sijnde op de bequaamheijt en ervarentheijd, 'tsedert eenen dienst van veele jaren in de qualiteijd van luijtenand over deselve natie alhier bij den Chinees Oeij tSomko verkregen, vervolgens verstaan en goedgevonden is den gemelden Oeij tSomko te verklaren en aan te stellen tot Capitein, opperhooft en voorsprake der meergemelde Chineesche natie en ingeseetenen te deser stede gelijk wij hem daartoe aanstellen, nomineeren en authoriseeren bij desen, om, met en benevens de thans nog resteerende luijtenands dier natie Tan Iko, Lim Koko en Souw tSoenseeng en diegeene, die wij wijders in vervolg van tijdt in dese of andere qualiteijd als hoofden en meede opsigters over die volkeren mogten goedvinden te stellen, de saken van gemelde ingesetenen, na behoren en onse ordres te manieeren, met even soodanigen magt ende authoriteijd als sijnen predecesseur Lim Beengkong heeft gehad, namentlijk omme met communicatie sijner luijtenants alle kleijne voorvallende zaken onder de Chineesen alhier uijt onsen name af te doen en te beslegten, dog de grote of andersints dubieuse te renvoijeeren daar 't behoord, mitsgaders verders alles te doen wat een goed, vroom en wacker Capitain, opperhoofd en voorsprake toestaad en betaamd, Ordonneeren ende beveelen derhalven aan alle hooge en laage officieren en specialijk die van den E. geregte deser steede, den voorsz. Oeij tSomko, daarvoor aan te neemen ende te erkennen, ook in alle saken sijn officie rakende, behoorlijk te maintineeren ende voor te staan, vorders aan alle Chineese ingeseetenen alhier ter plaatse, so die altans 
hier resideeren als die namaals nog soude mogen komen, denselven in sijn voorsz. officie alle behoorlijke gehoorsaamheijt, eere, hulpe ende bijstand toe te brengen ende te bewijsen, alsoo wij sulx ten dienste van de generale compagnie en het gerief en welstand der gemelte Chineesen alhier sodanig bevinden te behooren.

Gegeven in 't Casteel Batavia op 't Eijland Groot Java in 't Koningrijk Jacatra desen $6^{\text {en }}$ Junij $A^{\circ} 1747$, (was geteekend) G. W. van Imhoff, (in marg.) 's Comps zegul gedrukt in roden lacque (daar onder) Ter ordonnantie van hooggemelde haar Ed $^{\text {s }}$ (getekend) Ps. As. van der Parra, Secrs.

\section{d. Res. 9 Juni 1747.}

De voorstellinge van den bij resolutie van den 21 April pass $^{\circ}$ aangestelde Capitain der Chinese natie Oeij Tjomko door den Heere Gouverneur Generaal op morgen beraamt zijnde, Zo wierd goedgevonden en verstaan de schickinge van het ceremonieel daaromtrend aan Welgem ${ }^{e} Z_{\text {ijn }}$ Edelheijd gedefereert te laten.

Ter vervanging van den tot Luitenant bevorderden Li Hoko, werd Oeij Tsomko bij Res. van 23 Juni 1733 aangesteld tot Boedelmeester, in welk ambt hij in 1734 werd gecontinueerd.

Bij Res. van 28 Sept. 1736 werd hij benoemd tot Luitenant.

Hij behoorde tot de eersten welke 26 Sept. 1740 aan G. G. Valckenier kennis gaven van den opstand der Chineezen in de Bovenlanden; niettemin kwam hij in verdenking. Hij werd gedetineerd en den $14^{\text {en }}$ Oct. 1740 in verhoor genomen; den $20^{\circ \mathrm{n}} \mathrm{d}$. a. v. compareerde hij met zijn schrijver Oeij Djiko voor Commissarissen uit den Raad van Justitie om een Chineeschen brief te vertalen (waaruit blijkt dat hij Chineesch kon lezen); den $16^{\text {en }}$ November 1740 volgde zijn invrijheidstelling.

„De Chinees Luijtenant Oeij Tsjiomko en mede Chinees Lim Tsjouko verzoeken dat aan deselve uijt hoofde van haren deplorablen staat waarinne sij door de rebellie hunner natie sijn geraakt, speciaal mogte werden gequalificeert omme soodanige lijfeijgenen ten getalle van veertig stux van den eerstgem. en twee en vijftig van den laatsten, bij ontmoetinge hetsij op wat plaatsen deselve ook mogten komen te onthouden, na zig te mogen nemen en onder hare vorige magt en dienstbaarheijd te brengen, ten eijnde daardoor weder in staat te geraken hare vorige neeringe ten dienste van d'E Compe en het gemeenebest weder bij de hand te kunnen nemen waartoe sij anders onvermogend sijn. Soo wierd goedgevonden en verstaan, gem. Chineesen met dit hun verzoek tot den dagelijksen regter over te wijsen". (Res. 29 Nov. 1740).

„Den gew. Luijtenant over de Chineese natie alhier Oeij Tsomko bij requeste te kennen gevende dat hij door het afbranden en destrueeren van sijne huijsen en pedacken, het plunderen van alle sijne goederen en het missen van desselvs lijfeijgenen met de massacre en destructie onder 
sijne natie in $\mathrm{A}^{\circ}$ pass ${ }^{\circ}$ voorgevallen, althans gebragt sijnde in de uijtterste miserie en ten eenemaal onvermogend tot voldoening sijner crediteuren en uijt dien hoofde aan het eijnde van het rekest versoek doende omme van alle gijseling en rigoureuse vervolgingen van deselve te mogen blijven g'eximeert, onder aanneeming om 's jaarlijx aan deselve na rato en in mindering van hunne Caplen af te leggen een somma van $500 \mathrm{rds}$. So is ter sake het volle bekend zij dat zijne voorgeevens met de waarheid sijn quadreerende, goedgevonden het voorsz. versoek te accordeeren met committimus aan den E. geregte deser Steede". (Res. 25 Juli 1741).

In 1742 waarschuwde "Oeij Tsomko, gewezen luitenant der Chinesen" tegen een complot van de Mohamedanen tegen de Christenen en Chineezen (Res. 17 Dec. 1742).

Toen in 1743 opnieuw tot de aanstelling van Chineesche Hoofden werd overgegaan, werd hij weer tot Luitenant benoemd. (Res. 28 Juni 1743).

Zijne publieke voorstelling als Kapitein had plaats den 10en Juni 1747 (Zie Res. 9. Juni 1747).

Bij Res. 25 April 1747 werd besloten het huis van zijn voorganger Lim Beengkong voor ambtswoning van hem en zijne opvolgers aan te koopen omdat hij "door onvermogen of gebrek van middelen" buiten staat was dit zelf te doen. (Zie Bijdr. Kon. Inst., Deel 73 (1917) Bijl. V).

Aan den Capitain der Chineesen en pagter van d' inkomende en uijt. gaande regten Oeij Tsomko werd bij Res. 25 Aug. 1747 prolongatie toegestaan van de hem ter sessie van 6 April t.v. verleende surcheance van betaling der pachtpenningen tot ult ${ }^{\circ}$ November om reden van sijn onvermogen".

Uit Res. 17 Nov. 1747 blijkt dat hij toen 40 jaren lang te Batavia was. Hij was stellig in China geboren want bij Res. 16 Juni 1750 werd aan zijn executeur-testementair, den Lieutenant en Secretaris der Chineese natie Oeij Tjielauw, toegestaan zijn lijk „met eeṇ der eerstdaags te vertrekken jonken te laten transporteeren naar China om aldaar ter aarde besteld te worden, volgens het expresse-verzoek door den overledene ten dien eijnde gedaan". In de Res. van 7 Juli 1750 heet hij „onlangs overleden".

Kapitein Oeij Tsomko verzoekt remis van pachtpenningen (Res. 8 Aug. 1749) welke hem wordt toegestaan (Res. 16 Sept. 1749).

„Door den Capitain der Chineese natie Oeij Tsomko versoek gedaen zijnde om desselfs overleden huijsvrouw (Khoe Ki Etnio - zie Res. 25 September 1753) te mogen laten begraven met sodanige plegtigheden als onder lieden van conditie onder hare natie gebruijkelijk zijn en voor de Chineese revolte in $a^{\circ} 1740$ te deser stede aan een iegelijk uijt deselve gepermitteerd waren, zo is uijt aanmerkinge dat men sedert de regeringe van den praesenten heere Gouverneur Generaal op alle manieren getragt heeft die natie soowel ten opsigte van hare readmissie in dese Colonie en Stadt nevens den dagelijksen aanwas omtrend het getal als veel andere arrangementen soveel mogelijk is tot haren ouden stand te brengen, ten minsten daerna eeniger maten te doen gelijken, Goedgevonden en verstaen dat ook in het voorschreve versoek te condescendeeren en hetselve te extendeeren tot alle officieren van die natie en derselver familien, die daartoe in den aanstaende aan den heere Gouverneur Generaal versoek zullen doen". (Res. 26 Sept. 1749). 
„Brieven van atterminatie verleend voor drie jaren aan den Capit. der Chineese natie alhier Oeij Tjilauw als executeut in den boedel van desselfs overleden predesesseur Oeij Tsomko". (Res. 23 Febr. 1751).

Uit Res. 9 Juli 1754 blijkt dat Oeij Tsomko 30 April 1750 een testament heeft gemaakt (notaris Domburg) waarbij Oeij Tsjilauw - zijn opvolger - tot executeur werd aangesteld en dat de onder-coopman Anthonij Patras eene vordering op den boedel had.

\section{Oeij Tsjilauw.}

a. Res. 7 Juli 1750.

In plaats van den onlangs overleden Oeij Tsomko is verstaan tot Capitain van de Chineese natie, uijt degeene die daar toe haren dienst gepresenteerd hebben te verkiezen en aan te stellen den Lieut Oeij Tsjilauw, als daar toe de bequaamste en van een goede renommée zijnde, mids hij dientwegen naar het geresolveerde op den 21 April 1747 voor Scheepenen dezer stad op de Chineese wijze presteere den eed van purge.

\section{b. Batavia den $12^{\text {n }}$ Julij 1750 .}

Gustaaf Willem Baron van Imhoff, Gouverneur-generaal, mitsgaders de Raden wegens den Staat der Vereenigde Nederlanden en de Generaale geoctroijeerde Oost Indische Compagnie in India, allen dengeenen die desen sullen sien ofte horen leesen, Salut, doen te weeten:

Alsoo den Capitein der Chineese natie alhier Oeij Tsomko onlangs is komen te overlijden en het derhalven vereijscht, dat weder een ander bequaam en wacker man tot Capitain en hoofd over gem. natie werde gestelt, so is het, dat in Rade van India op den $7^{\mathrm{n}}$ deser maand daarover gedelibereert, en gelet zijnde op de gegevene preuves van bequaamheijt en integriteijt in de qualiteijten van Lieutenant en Secretaris, bij den Chinees Oeij Tjielauw, vervolgens verstaan en goedgevonden is den gem. Oeij Tjielauw te verkiesen en aan te stellen tot Capitain, opperhoofd en voorspraake der meergem ${ }^{e}$ Chineese natie en ingesetenen te deser plaatse, gelijk wij hem daartoe aanstellen, nomineeren en authoriseeren bij desen om, met en benevens de thans nog resteerende luijtenants dier natie Limkocko, Souw Tsoenseeng, Tanwangseeng en Lim Tjipko en diegeene die men nog wijders in het vervolg van tijdt in dese of andere qualiteijten als Hoofden en medeopzigters over die volkeren mogten goedvinden te stellen, 
de saken van gemelde ingesetenen na behoren en onse ordres te manieeren, met even sodanigen magt ende authoriteijt als sijnen predecesseur Oeij Tsomko heeft gehad, namentlijk omme met communicatie sijner luijtenants alle kleijne voorvallende saken onder de Chineesen alhier uijt onsen name af te doen ende te beslegten, dog de groote of andersints dubieuse te renvoijeeren daar het behoort, mitsgaders verders alles te doen wat een goed, vroom en wacker Capitain, opperhoofd en voorspraeke toestaat en betaamt, Ordonneeren en beveelen derhalven aan alle hooge en lage officieren en specialijk die van de $\mathrm{E}$. Geregte deser steede, den voorsz. Oeij Tsielauw daar voor aan te neemen ende te erkennen, oock in alle saken sijne officie rakende, behoorlijk te mainctineeren ende voor te staan, verders aan alle Chineese ingesetenen alhier ter plaatse, so die althans hier resideeren als die namaals nog souden mogen komen, denselven in sijn voorsz. officie alle behoorlijke gehoorsaamheijt, eere, hulpe ende bijstand toe te brengen ende te bewijsen, also wij sulx ten dienste van de generaale Compagnie en het gerief en welstand der gem ${ }^{\mathrm{e}}$ Chineesen alhier sodaanig bevinden te behooren.

Gegeven int Casteel Batavia op 't Eijland Groot Java int koningrijk Jacatra onder het groot zegul van de Generaale g'octroijeerde Oost Indische Compe desen $12^{\mathrm{n}}$ Julij 1750 (was getekent) G. W. van Imhoff (ter zijden stond) 's Comps zegul gedrukt in rooden lacque (en daaronder): Ter ordonnantie van hooggem. haar Edelens (getekent) Louis Taillefert Secrs.

\section{c. Res. 15 Juni 1751 .}

Laastelijk is op het versoek van den $7 \mathrm{Julij}^{\circ} \mathrm{pass}^{\circ}$ aangestelden Capitain der Chineesen natie Oeij Tsjielauw, verstaan denselven naar het exempel van sijn voorsaat in $A^{\circ} 1747$ te laten voorstellen, volgens het doenmaals door den heere Gouverneur Generaal Baron van Imhoff (G. G.) gereguleerde ceremonieel ingevolge het besluijt deser regeering van den $9^{\text {en }}$ Junij desselven jaars.

\section{d. Res. 26 Maij 1747.}

In steede van den tot hier toe in gebruijk zijnde ongequalificeerde schrijver teffens het emplooi van Secretaris bij de Chineese officieren ook als translateur in de Chineese tale fungeerende, onder het genot van 150 rds. 'sjaars die voormaals Dl. 78 . 
door boedelmeesteren aan hem wierden uijtgereijkt in de qualiteijt van schrijver bij den Capitain der chineesen alhier, is verstaan zodanigen persoon voortaan bij dese regeering tot Secretaris der vergadering van Capitain en Lieutenants der Chineese natie op haar daartoe gedaan versoek aan te stellen en alsoo ditmaal den daartoe voorgedragene Chinees Oeij Tjie Lauw en denselven uijt de cas van boedelmeesteren toe te leggen het voorm. tractement van 150 rds 'sjaars, ter resol. van den 4 October 1695 aan de soodanige toegesegt met permissie tot het dragen van eenen groote quitasol, en denselven ook nopens de getrouwe waarneming dier dienst bij Schepenen te doen beedigen, mitsgad $^{\text {s. van }}$ zijne aanstellinge kennisse te geven aan de beijde Collegien van Justitie en dat van boedelmeesteren voormeld.

Hij legde blijkens Res. 9 Juni 1747 den eed af als Secretaris volgens het in die Resolutie ingelaschte formulier. Bij Res. $11 \mathrm{Juli} 1747$ werd verstaan hem "te accorderen evenals aan Chinese Boedelmeesteren vijf Chineesen vrij van de betaling van het hooftgeld".

Hij werd bevorderd tot Luitenant bij Res. van 10 Dec. 1748.

In ${ }_{n} B i j d r a g \nrightarrow n$ tot de kennis van de wetten en instellingen der Chinezen in Nederlandsch-lndië" (Tijdschrift van N. I. 15e jaargang, 10 deel, bl. 243) wordt aangehaald de res. van 22 Mei 1761 (N. I. Plakaatboek VIII, 476) waaruit blijkt, „dat het voornamelijk de toenmalige kapitein der Chinezen te Batavia Oei Tjilauw was geweest door wiens inlichtingen men deze wetten had samengesteld".

Bij Res. 6 Maart 1752 werd aan Boedelmeesteren vergund de reparatiekosten ad rds 430.18 aan de ambtswoning af te schrijven "mits het bekend onvermogen van den praesenten Capitain Oeij Tjielauw om te voldoen aan de conditie dat hij buijten de betaling van vier en een half $\mathrm{p}^{r} \mathrm{c}^{\circ}$ 's jaars van het kostende ook sal gehouden wesen om die opstallen in een behoorlijken staat te houden en alle voorkomende gebreeken te repareeren".

Ter bestrijding van de kosten der aan hem en de Luitenants opgedragen beschrijving der Chineesche natie (ordonnancie 13 Mei 1754) verzocht hij eene door de Regeering te bepalen contributie te mogen heffen. Dit werd hem geweigerd; "na absolvatie van de hem geinjungeerde commissie" kon hij aan de Regeering "presenteeren eene notitie van sijne gemaakte depenses". (Res. 27 Aug. 1754). De Regeering verstond echter "geensints to consenteeren in eene contributie die de apparentie met sig draagt van door baatsugtige insigten gemachineert te wesen".

Hij kreeg bij Res. 23 Jan. 1756 eene maandelijksche toelage van 370 rijksdaalders na indiening van een verzoekschrift "tendeerende dat aan hem uijt hoofde van verscheijde onkosten en depences die hij bij diverse gelegentheden genoodsaakt is te doen en door een aloude usantie geworden sijn als servituten van gemelte sijnen dienst aan dewelke geene de minste voordeelen waren geaccrocheerd, eenig middel van bestaan tot goedmaking derselve mogte werden toegelegd". De Regeering overwoog "dat al van een menigte jaren herwarts aan sijne voorsaten eenige 
douceuren soo tot goedmaking harer kosten als om hun eenigzints boven anderen van bare natie te kunnen distingueeren, sijn toegevoegd en tot welk sijnde wel ten principale gedient heeft de pagt van de pho en topho aan de vorige Capitains als aan den suppliant tegens een mediocren prijs in admodiatie afgestaan dog die jongst na het gearresteerde ter sessie van den $23^{\text {en }}$ December passati, te samen met die van de topbanen is verpagt geworden".

Voldeed hij als Kapitein zoo slecht dat hij op een klacht van de Luitenants werd afgezet ( $\mathrm{Zie} \mathrm{XV}$ ), in zijne zaken en in zijn huwelijk was hij evenmin gelukkig.

Aan den gewezen Capitain der Chineese natie alhier Oeij Tjilauw werd vijf jaren respijt verleend. Zijne gezamenlijke crediteuren hadden, volgens zijne opgave, Rds 5370 van hem te vorderen. (Res. 14 April 1758).

„Door den oud-Capt ${ }^{\mathrm{n}}$ der Chineese natie Oeij Tjilauw verzoek gedaan zijnde om brieven van atterminatie te mogen erlangen ten eijnde zijne crediteuren die hem dagelijks lastig vielen en overvielen met proceduren en executies, binnen den tijd van ses jaeren met een sesde parte hunner pretensies 's jaers te voldoen, so is verstaen sulx te accordeeren en daervan aen den Suppl ${ }^{t}$ brieven in forma te expedieren met committimus van den geregte deser stede". (Res. 11 Aug. 1761).

"Na lecture van een appointement van Scheepenen der stad op den 7 dezer geslagen tegen de Chineese vrouw Lie Quanio, wijf van den gew. Cap ${ }^{\mathrm{a}}$ der Chineese natie Oeij Tsilauw, waarbij dezelve gecondemneerd werd voor de tijd van 5 jaeren van hier gerelegeert te worden. Zo is verstaen gem. Lie Quanio ter voldoening van die condemnatio na Ceijlon te versenden en haer intusschen bij provisie op 't eijland Edam te plaatsen". (Res. 8 Sept. 1761).

„Op de demoedige supplicatie van de Chineese vrouw Lie Quanio, wijff van den oud-Capitein der Chineesen Oeij Tsilauw, om gedurende de tijd van haar vijfjarig bannissement, waarin zij door den geregte dezer stad gecondemneert is, op het eijland Edam, alwaar zij zig in een siekelijke staat bevind, te mogen verblijven, zoo is verstaan sulks te accordeeren en gem. wijff in steede van volgs resolutie van den 8 en September jongstleden na Ceijlon verzonden te worden, ter voldoening aan gemelte condemnatie voor gem. vijff jaaren op 't eijland Edam verbannen te laten blijven, wijl het dog 't selve is op wat plats door haar aan de sententie voldaan word". (Res. 16 Oct. 1761).

\section{Lim Tjipko.}

\section{a. Res. 27 Augustus 1756.}

De respective Officieren der Chineese natie in dese Colonie bij een geschrift te kennen gegeeven hebbende dat, tot vilipendi der successive ordres deser Regeering, nog onlangs, of bij Resolutie van 25 Februarij 1752 gerenoveerd, veele van die natie sig niet ontsagen, hun hier te onthouden, sonder van permissie briefjes voorsien te weesen, dat niets anders konde opereeren 
dan een reeks van ongebondheeden en allerleij disordres; dat sij om daarin, ter betragting van hun pligt, te voorsien de nodige middelen, dog sonder effect, hadden te werk gesteld, mitsgaders om die reden versoek kwamen te doen, te mogen werden gemunieerd met nadre ordres, over welk sujet gedelibereerd en daar bij in consideratie genomen sijnde dat de conduite van den presenten Capitain Chinees in name Oeij Tjilauw ongetwijffeld de wortel oorsaak sal sijn van het illicite en ongehoorsaam gedrag dergeene waar over hij tot Hoofd is aangesteld, en bij welke hij, van den meesten tot den minsten toe, door zijne mechante levenswijse in veragting geraakt is en alle credit verlooren heeft, invoegen de so hoog nodige subordinatie onder en respect voor de Officieren niet schijnt te kunnen werden gerepareerd dan in de dimotie van voornoemden Oeij Tjilauw, en dat die plaatse hoe eerder hoe liever werde gesuppleerd door een ander vigilant en onder die natie in agting sijnde supject, en welke de vereijschte bekwaamheijt heeft om alles op een goeden en geregelden voet te schikken, So is goedgevonden en verstaan den meerm. Oeij Tjilauw af te setten, en in sijne plaats tot Capitain der Chineese Natie alhier te benoemen en aan te stellen den Lieutenant Lim Tjipko, en voorts tot Lieutenant te laten optreeden den Chinees Khouw Hongliang, mitsgaders wijders den Bailliuw en Landdrost, item Commissaris tot en over de zaken van den inlander, bij renovatie der vorige ordres, serieus te gelasten, de Chineese officieren des nodig te assisteeren, alles in naarkoming der Placcaten op dit stuk.

\section{b. Dagreg. Saturdag 19 Februarij anno $1757 .{ }^{1}$}

Heede wierd ingevolge van het geresolveerde in Rade van India op den 11 deser, den lieut ${ }^{t}$ der Chineesen Lim Tjipko, die in steede van den gedemoveerde Oeij Tjilauw tot Cap ${ }^{n}$ over d'Inwoonders en aankomende negotianten van zijne natie te deeser plaatse op den 27 Augustus des gepasseerde jaars in voorm. Rade aangestelt sijnde, op een statieuse wijse na het jongste voorbeeld van den jaar 1747, de gemeente publicqlijk voorgesteld.

1 Landsarchief. Het origineel van dit stuk van 1757 is zeer moeilijk te lezen, en de tekst dientengevolge niet absoluut zeker. De tekst van Dagregister 8 Juni 1747 komt veel hiermee overeen en kon ter verbetering worden aangewend.

-- Aanteekening van Dr. de Haan, van wien ook de noten zijn. 
Ten dien eijnde twee ordinaire Leeden uijt den agtb. Raad van Justitie deses Casteels benevens den advocaat Fiscaal van India en den waterfiscaal, als mede twee leden uijt het Collegie van Scheepenen met den baillieuw en landdrost g'adsisteert met de Secretarissen van beijde de voorm. Collegien, door Zijne Excellentie den Heere Gouverneur Generaal tot het verrigten en bijwonen dier plegtigheeden expresselijk gecommitteert weesende, quamen deselve nevens de nieuwe gem. Cap ${ }^{n}$, verzeld van de vier lieutenants der Chineesen, alle op het cierlijkste met haar hooge mutsen ${ }^{1}$ en lange tablaarden of ceremonie rocken na derselver gewoonte [opgetooijt] ${ }^{2}$ en gekleed des voormiddags omtrent neegen uuren aan het woonhuijs van hoog gem $^{\text {te }}$ sijne Excellentie staande aan de westzeijde van de Groote revier, die aan haar gesamentlijk het voorm. besluijt aangesegt en de geprepareerde commissie voor den Gemelten hoofdman in 't nederduijts en in 't Chinees op pargament geschr. de gecommitteerdens van welgem. raden van Justitie ter hand gesteld hebbende met bijvoeging dat se met de voorstelling soude believen voort te gaan, namen deselve afscheijd van sijn Excellentie, werdende onder het uijtgaan door de bij sijne Excellentie wagthoudende dragonders met 't ordinaire honneur, dog sonder de trompet te blasen gesalueert, en daar benevens tot een Escorte toegevoegt een Corps van 12 Militairen opgevoerd door een sergeant, de welke, nevens een menigte van Chineesen die tot het bijwonen en aankomen ${ }^{3}$ van deese voorstelling daags bevoorens met beckenslag waren gewaarschout, en die met een groot getal vlaggetjes en vanen van allerhande couleuren op de wijse van praal bogen ${ }^{4}$ gemaakt als mede diverse hoge stellagien van

1 Over die hooge mutsen: zie de plat (van Rach) van het Observatorium te Batavia bij Bosboom's opstel in Tijdschr. Bat. Gen. dl. 44 (1901), bl. 158. Ook op andere platen van Rach komen personen met zulke mutsen voor, die dus Chineezen zijn. Dezelfde mutsen dragen Chineezen nog bij begrafenissen.

Vgl. ${ }_{n}$ Aengaande den oorloch verhaalen [de Chineezen dat] den Tarter Nankijn 't eenemael overweldicht ende onder sijn subjectie gebracht heeft, corsaacke waeromme $d^{\circ}$ chinesen haer op de maniere gelijck de Tartaaren met een kuijff op de kruijn van 't hooft hebben moeten bescheeren, so dat alle de Chineesen met de joncke [uit Nankin] aengecomen, uijt schaampte haer hooffden te ontdecken, mutsen draagen." (Dagr. Nagasaki 17 Juni 1646).

' aanvulling uit Dagr. 1747.

3 aanhooren?

${ }^{4}$ Dagr. 1747: een menigte van Chineese zijde vaandels en wimpels bij wijse van praalbogen gemakt. 
bamboesen op een cierlijke manier met gecouleurde linten en papieren toegesteld, waar op sig Jonge Chineese kinderen, in allerlij nagebootste postuuren vertoonde onder het geluijt van blaashoorns, ruijschpeijpen, bazuijnen en andere Inlandse speeltuijg, de coetsen van de gecommitteerdens verzelden tot aan het stadhuijs de bovengem. commissie alwaar, van 't balcon na dat hun eenige tijd in de vergadersale van haar Agtbaarhed"s gerefrecheert, en 't gewoonelijke Justitie klokie drie maal geluijd was geworden, door den secretaris van heeren scheepenen in 't nederduijts en door den Chinesen bode in 't Chinees, de gemeente wierd voorgeleesen waarna de voormelde gecommitteerd met haar geselschap in voegen voorschr. nae sijn Excellentie begeevende, vonden sowel de wagthebbende militie aan de middelpunts brug in volle wapenen van welke in 't voorbij gaan d' ordinaire marsch wierd geslagen, als de dragonders van $\mathrm{Zijn}$ Excellentie dien hun als voren gemeld salueerde, en voorts van die verrigting rapport aan hooggem. sijn Excellentie gedaen hebbende, wierd de commissie door sijn Excellentie den gem. $\mathrm{Cap}^{\mathrm{n}}$ ter hand gesteld, onder recommandatie van deese zijne verkreegene digniteijt na het oogmerk en genoegen van de hooge regeeringe, ten dienste en welweesen van het gemeen te exerceeren, en daar op het geselschap wat refrischementen aangeboden, en de gem. gecommitteerds voor haar genomene moeijte vervolgens bedankt sijnde namen deselve afscheijd, wanneer intussen 't corps aftrok, en de gem. gecommitteerd' weder na huijs reeden, zonder dat als doen door de Dragonders gesalueert wierden, vertoefden de Chineesen een wijl tijds voor sijn Excellenties wooning $\mathrm{nu}^{1}$ met hare geprepareerde en binnen gebragte verderen toestel der Extraordre gelegentheijd met nadere uijtterlijkheeden op te pronken, en de mitsdien d'ontfangene en toegerolde commissie in een sakje van geel damast gestoken hebbende, wierd deselve gelegt onder een soort van verheemelte eenigermate thorensgewijse ${ }^{2}$ op een kleine Chineese tafel gefabriceert staande, van binnen met geel damast cierlijk bekleed en behangen, en van buijten of aan de zijden met eenige beugels en twee ronde stokken off draagbomen voorsien zijnde, en dus in sijn gevaarte bijna de gedaante van een rosbaar verbeeldende, die ook door ses rustige Chineesen, omhangen en gehuld met

1 Dagr. 1747: omme.

2 Dagr. 1747: troonsgewijse, 
rode rocken, en callotten wierd opgenomen, en op de schouders gedragen; voorgegaan werdende door de Chineese bode, omhangen sijnde met een roode armozijnen scherp en twee geleerste Chineesen, ijder met een grote sweep in de hand, en tusschen haar beijde een anderen Chinees dragende een swirige seijde sonnenscherm en voorts gevolgd onder een stemmige contentatie $^{1}$ door voormelten $\mathrm{Cap}^{\mathrm{n}}$ en de verdere Chineesen rijdende dus al segenpralende met verheffinge van 't geblaas van haar musicale getuijg naar het huijs van voormelten Capn Chinees staande in de Jonkerstraat, of zogenaamde zandzee en van daar weder ingelijker voegen terug na deszelfs woonhuijs buijten de stadt, staande even buijten de Rotterdammer poort, in de door de wandeling genoemde ribaldsgang, alwaar een genodigt gezelschap van omtrent 80 persoonen so van de hoge regeering als hoge en lage gequalificeerdens pragtig ter maaltijd onthaald geworden, en dewelke voorts den middag en avond onder diverse vertoningen van Chinese waijangs en andere Inlandse spellen door bragten, so dat aldaar een gedurige confluentie so van genodigde als toekijkers-den gantschen dag geweest is.

Lim Tjipko werd benoemd tot Luitenant bij Res. 3 Juni 1749.

Op zijn verzoek werd „aan hem en zijne successeuren de pacht van de Pho- en Topho afgestaan tegen betaling van $300 \mathrm{rds}$ 's maands met cessie van zijn maandelijksch genot in gelde, dewijl het ten vollen bekend is dat die Officieren ambtshalven genoodzaakt zijn naamwaardige depenses te doen en een beter middel van bestaan meriteren." (Res. 20 Dec. 1757).

In Res. 19 Mei 1769 wordt gesproken $n . .$. van 't bijzonder genoegen 't welk deeze Regeering in 't gezag van den tweeden Suppliant [Kapitein Lim Tjipko] over die van zijne natie gevoerd heeft."

Een rekest van hem over de begraafplaats te Goenoeng Sahari wordt behandeld bij Res. 6 Oct. 1761 .

Volgens de „Chronologische Geschiedenis” overleed hij 23 Jan. 1775.

\section{Ting Ingko.}

a. Res. 31 Januari 1775.

Tot Capitain der Chineese natie alhier, in plaatze van den overleeden Lim Tjipko, is goedgevonden en verstaan te laten optreeden den oudsten Luitenant Ting Ingko, als daartoe de vereischte bequaamheid en agting bij de natie hebbende, en de

${ }^{1}$ Dagr. 1747: in een stemmig gelaat. 
publicque voorstelling van denzelven op een nader te bepalen dag te laten geschieden, naar die van zijnen gemelden antecesseur, bij het Bataviasch Dagregister van het jaar 1757 aangetekend.

b. Dagreg. 3 April $1775 .^{1}$

Maandag 3. Zijnde den bij besluit van den 21 Maart bevoorens bepaalden dag tot de publique voorstellinge van den Capitein der Chineeschen Ting Inko, naar het voorbeeld van den op den $19^{\text {n }}$ Februari 1757 voorgestelden dog jongst overledene Capitein Lim Tjipko;

Des morgens om half zeven uuren posteerden zig voor de wooninge van $\mathrm{Zijn}$ Hoog Edelheid aan de weg van Jaccatra Hoogst deszelfs Granadiers Lijfwagt en buiten dezelve op den weg een detachement van 12 Granadiers onder een sergeant en corporaal; om zeven uuren arriveerde Hoogst gedagte Zijn Edelheid van Deszelfs Lustplaats Weltevreeden en verscheenen ook te dier tijd, de door den Eerstgezworen klerk de Bock ter ordonnancie van Hoogst gedagte Zijn Edelheid geappointeerde twee ordinaire Leden uit den Agtbaaren Raad van Justitie, de Heeren Maas en Wichers, den Advocaat Fiscaal van der Vorm, den water fiscaal Poelman, den Secretaris Welgevaaren nevens twee Leden uit het Eerwaarde collegie van Schepenen zijnde de Heeren Wiegerman en Vermeulen, met den Baillieuw Radermacher, Drossaard Pook en Hun Eerwaarden Secretaris Lodisio alle tot die plegtige voorstelling geschikt.

Intusschen waren op order van Hoogstgedagte Zijn Edelheid de wagten van de stad en het Casteel, uitgenomen de dragonder Lijfwagt binnen het Casteel, verdubbeld en de aankomende of nieuwe wagten gesteld onder commando van den afgaanden officier.

Alle de verdere Officieren waren gelast zig bij de hand te houden, ten einde zig op de eerste Extraordinaire beweeging bij hunne compagnien te voegen.

De wagtvrije onder-officieren en Gemenen moesten bij haare compagnien blijven, tot de oude wagten afgelost en in hunne Logementen terug gekomen waren. De Dragonder Lijfwagt, zoo verre zij wagtvrij was te Paard zitten en op het Plein voor het Casteel maneuvereeren.

De Artilleristen moesten alle op hunne aangeweezene posten blijven ;

\footnotetext{
1 Landsarchief.
} 
Twee compagnien Burgers in de Wapenen komen voorzien van scherpe Patroonen en haär posteeren voor het Stadshuis op de blauwe steenen.

En een wagt Burgers van 1 officier, 2 onder-officieren en 24 Gemeenen post vatten aan de Jassembrug; circa half agt uuren verscheen den trein in volgender voegen:

156 Chineesche eerenwimpels van diverse couleuren aan bamboesen gereegen en door 312 slaven gedraagen.

156 Chineesche Lantaarns van diverse soorten alle op lange stokken door 312 slaven gedraagen.

16 Draagzetels door diverse persoonen gedraagen verbeeldende eenige rotsen grotwerken, geboomtens enz. waar op zig verscheidene kinderen in diverse postuuren en kleedingen vertoonden alle zeer kunstig naar hunne Landswijze bij een gesteld.

18 Jongelingen alle te Paard rijdende gehoorende tot de voormelde vertooningen.

8 Stellen met diverse blaasinstrumenten gehoorende tot de 74 ornamentendraagers, die alle in donker blaauw gewaad gekleed en verscheiden soorten van mutsen gedekt zijn, agtervolgd door

2 Chineeschen te paard rijdende ieder met een Trompet in de hand.

2 Chineeschen als Bekkenslaagers.

$2 d^{\circ} \quad$ die elk een vierkante houte blad op een stok hebben gedraagen, waar op met vergulde Chineesche letters geschreven stond de betekening van het woord Silentium.

2 Chineeschen die elk als vooren gedraagen hebben de betekening van het woord, maak ruim baan voor die, die agter volgen zal.

2 Chineeschen draagende ieder een vaandel, waarop een draak geschildert staat zijnde een der eerste vaandels der Chineeschen.

2 Chineeschen draagende ieder een roode stok met een hand daar op houdende eene Chineesche pen of penceel, beteekend, wat geschreven staat moet geschreven blijven.

2 Chineeschen draagende ieder een vaandel waarop een Tijger geschilderd staat, is het tweede vaandel der Chineeschen.

2 Chineeschen draagende ieder een roode stok met een vuist daar op, houdende een zwaare ringbout, betekend, dat een opregt en wijsbestierer zig altoos bepaalen zal, na zijn vermogen. 
2 Chineeschen die ieder een vaandel draagen waarop een Landschildpad geschilderd staat, is een wapen van een der verstandigsten Chineesche Keijzers, die volgens hunne kronijk geregeerd hebben.

2 Chineeschen draagende ieder een breede kapbijl betekend zoo er iets in den weg van een Mandarijn Legt zulks ten eersten uit den weg moet geruimd worden.

2 Chineeschen draagende ieder een vaandel waarop een slang geschilderd staat, is mede een wapen van een Chineesche Keijzer geweest.

2 Chineeschen draagende ieder een piek met een buik snijder daar op; zijnde trawanten van den Mandarijn;

2 Chineeschen draagende ieder een vierkantig bord op een stok, waarop in het Chineesch geschreven staat de qualiteit en staat van dien Mandarijn, die agter volgen zal om te weeten wat honneur hem toekomt.

2 Chineeschen draagende ieder een vaandel waarop in het Chineesch geschreven staat de volgende woorden maakt de wegen schoon en effen voor den Mandarijn of Capitein Chineesch.

2 Chineeschen draagende ieder een stok met een draakenkop daar op, betekend ongeveinstheid.

2 Chineeschen draagende ieder een stok met een soort van een morgen stair daar op betekend, zoo klaar die zig aan den Hemel vertoond, alzoo klaar en op regt de bestiering van den Mandarijn zal weezen.

2 Chineeschen draagende ieder een stok waar op een bol met 12 kleine vlaggetjes gesteld zijn, betekend, wanneer een Mandarijn een van zijne trawanten elders wil heen zenden, wordt hem altoos een van de 12 gemelde vaandeltjes tot een bewijs van den Mandarijn mede gegeeven.

2 Chineeschen slaande ieder op een koperen bekken.

2 Chineeschen draagende ieder een vaandel, waarop geschreven staat de Landtogt die zoo een Mandarijn zal doen, omme naar jaarlijksche usantie alle geschillen, die tusschen de mindere opperhoofden en Dienaaren gerezen zijn te slegten.

2 Chineeschen draagende ieder een gespleeten bamboes, betekend zoo een Mandarijn in nood is om zijn gevoeg te doen en hij nergens een bequaame plaats daar toe kan erlangen deeze twee persoonen hem met de voornoemde geuten moeten adsisteeren. 
2 Chineeschen draagende ieder in haar regterhand een ronde korte stok en in de linkerhand een lange stok vol knoesten, en teffens betekend, de Geregtigheid.

2 Chineeschen die ieder een opgeschoten Lijn draagen om die gene die admortem verweezen zijn daar mede vast te binden.

2 Chineeschen die ieder een zwaard van Justitie draagen.

2 Chineeschen te Paard rijdende, draagende ieder een vierkante blad op haar rug waar op in het Chineesch geschreven staat, Een Hofmeester van den Mandarijn.

2 Chineeschen te paard hebbende ieder een houte spaan in der hand, om alle die in den weg staan uit den weg te slaan.

2 Chineeschen te paard, hebbende ieder agter op haare lenden 5 kleine vlaggetjes, betekend de 5 Hoofd Provincien in China wanneer in de een van de vijf Provincien oorlog is, dan zend zoo een Mandarijn iemand met een diergelijke vlaggetje van die Provincie, waar bij hij om bijstand van volk verzoeken doet.

2 Chineeschen die ieder een ketting in de handen hielden, om de quaaddoenders daar mede aan den hals te boeijen.

2 Chineeschen te paard hebbende ieder een standaart in de hand daar een draak op geschildert staat.

1 Chinees te paard met een klein kiepersol van de ondermandarijn.

2 Chineeschen te paard draagen de eene de inkt, penne, en papierkooker en de andere de commissie van den Mandarijn in een vergulde kooker.

8 Chineeschen alle te paard rijdende met diverse speel-instrumenten.

2 Chineeschen die ieder een Bulle pees in de hand houdt om het volk uit den weg te slaan.

Een vergulde Draagzetel, waar in de acte van den Mandarijn wordt gedraagen door 8 persoonen.

Een draagzetel waar in de klederen en verschoning van den Mandarijn worden gedragen door 2 personen.

Een Chinees die de staat kiepersol [draagt] van den Mandarijn.

2 Chineeschen te paard rijdende met pijl en boogen.

Een Persoon te paard verbeeldende den vice of ondermandarijn.

2 Chineeschen hebbende ieder een gespleete bamboes in de hand daar ze door Last des Mandarijns de quaaddoenders mede straffen. 
2 Chineeschen draagende ieder een roode stok met een vergulde knop of bal daar op, zijnde de voorloopers van den Mandarijn.

2 Chineeschen draagende ieder een houte bus met eenige gespleeten bamboesjes daar in, betekend zoo een Mandarijn een quaad doener straffen wil zoọ neemt hij een van die bamboesjes en smijd die ter aarde neer, 't welk vijf slagen beduit; smijd hij er twee beduit tien slagen, drie beduit vijftien slaagen, hooger komt hij niet.

2 Chineeschen zijnde de vertrouwelingen van den Mandarijn. Een Chinees draagende de groote waaier van den Mandarijn.

2 Chineeschen draagende ieder een wierookconfoor met vuur, betekend, wanneer den Mandarijn iets onreins of stank ruikt door den draager eenige welruikende gommen moeten gerookt worden.

Een verhemelde draagzetel waar in den mandarijn door agt persoonen gedraagen wordt.

2 Chineeschen in het zwart satijn gekleed en te paard rijdende ieder met een vaandel van den Mandarijn.

Een Chinees mede in het zwart satijn gekleed is een officier van den Mandarijn.

4 Chineeschen draagende ieder een stok met een buiksnijder daar op.

4 Chineeschen hebbende ieder een knuppel in de handen.

4 Chineeschen draagende ieder een blaauwe kleine vlag.

7 Wagens ieder bespannen met twee paarden waar in gezeeten waren de zes Luitenants met hunnen Secretaris.

Wordende deezen Train opgeslooten door een corps van ruim een honderd Papangers met lange pieken en krissen op de Javaansche wijze en yoorzien van diverse Inlandsche speel-instrumenten, als gandangs, gomgommen, enz.

Waar op den Capitein uit zijnen draagzetel treedende gevolgd wierdt door de zes Luitenants en hunnen Secretaris alle gekleed in hunne plegt gewaaden zijnde lange bruine tabbarde en hooge spits toe loopende mutzen of hoeden gaande door het dubbeld ranquet Granadier Lijfwagt naar Hoogstgedagte Zijn Edelheids wooninge, in dewelke zij nevens de Gecommitteerde Leden uit den Raad van Justitie en Schepen nevens de officieren en Secretarissen plaats genomen hebbende wierdt onder te kennen gave van het voorschr. besluit de commissie door Hooggemelde zijn Edelheid aan het Eerste Lid des Raads de Heer Maas 
inhandigt, met bijvoeging dat ze met de voorstelling geliefden voort te vaaren; waar op de gezaamenlijke Gecommitteerden nevens den Capitein en Luitenants van $\mathrm{Zijn}$ Edelheid afscheid namen geleidende den Heer Maas voormeldt den Capitein bij de hand door het dubbelde ranquet Granadiers die het geweer presenteerden, gevolgd door de verdere Gecommitteerde en de Luitenants naar het Hek, alwaar den Heer Maas zig aan de Linker zijde van den Capitein in een der waagens begaf voorgegaan door het hier voor vermelde detachement Granadiers en waar na de Gecommitteerde nevens de Officieren, Secretarissen en Luitenants, twee aan twee in een wagen rijdende met dezelve statie langs den weg van Jaccatra over de Jassembrug naar de Nieuwpoort, door dezelve en de straat van die naam naar het Stadhuis, wordende door de wagt aan de Jassembrug, aan de Nieuwpoort en door de Burgerwagt voor het Stadhuis het geweer gepresenteerd.

De Gecommitteerde nevens den Capitein en verdere Heeren binnen het Stadhuis getreeden zijnde, vervoegden zig naar de vergader-kamer van hun Agtbaarheden en vervolgens van daar naar het Balcon, wordende intusschen drie maalen het gewoone justitie klokje geluid, waar naar de commissie in het Nederduitsch door den Secretaris van schepenen en in het Chinees door den Boode van die natie den volke wierdt voorgeleezen, hier na begaven zij zig weder gezaamenlijk naar hun Agtbaarheden vergaderkamer en vervolgens van daar weder in hunne rijtuigen rijdende op voorgaande wijze de nieuwpoort straat en nieuwpoort door naar Jaccatra alwaar zij voor den tuin van Zijn Hoog Edelheid weder genadert zijnde uit hunne rijtuigen stapten, en door het dubbeld geschaard corps Granadier Lijfwagt onder het presenteeren van het geweer weder naar binnen marcheerden, doende van hunne volbragte commissie het verschuldigde raport aan Hoogstgedachte Zijn Edelheid; intusschen deed de Granadier Lijfwagt de afmarsch en het escort granadiers naar hunne compagnien terug.

Waar op $\mathrm{Zijn}$ Hoog Edelheid de Commissie van den Heer Maas te rug ontvangen hebbende, dezelve onder een gepaste aanspraak en met de vereischte recommandatie den Capitein ter hand stelde en de meermelde Gecommitteerde voor hunne moeite bedankt hebbende namen zij alle gezaamenlijk afscheid en vertrok een ieder naar zijne wooning, wordende als doen de 
voormelde Commissie gelegt in de hier voorengemelde vergulde draagzetel door agt persoonen gedraagen en door de Capitein en zijne Luitenants 'op dezelve wijze als hier voor gevolgd zijnde namen zij hunne route langs Jaccatra voor bij de tuin van den Heer oud Gouverneur de Kothlings om voor bij de Granadier Lijfwagt naar Sontar alwaar zij wederom links zwenkende over Jassembrug naar de Nieuwpoort door dezelve en de straat van die naam, langs de Groote Hollandsche kerk, en de Pisang passer over de middelpunts brug, langs de westzijde van de Groote rivier, de waag, de visch en rijstmarkt naar de Ankerstraat, door dezelve naar de Ankerwerf en vervolgens links af naar de Sandzee in dewelke zij bij den vlaggenstok voor de wooning van den overleden Capitein hald hielden en naar binnen traaden zijnde hunne vergadering belegt en naar eenige pligt pleegingen volgens haare Landsaard geschied zijnde vertrokken zij weder van daar langs de westkant van de roea malacca over de brug bij de Portugeesche kerk, langs dezelve, naar de groote rivier door de Diestpoort over de brug van 'de Bamboese passer naar het Chineesch quartier en door hetzelve voor bij Patoeakan naar de wooning van den Capitein aan de rivier Ankee alwaar deeze buitengewoone plegtigheid, door een genoodigde Gezelschap zoo van de Heeren der Hooge Regeeringe als van de Hooge en mindere Gequalificeerde Dienaaren en voornaamste Burgers des avonds aldaar pragtig ter maaltijd onthaald, beslooten wierdt.

Ting Ingko werd benoemd tot Luitenant bij Res. 6 April 1764.

Hij legde 31 Maart 1775 den eed van trouw en $10 \mathrm{~A}$ pril 1775 dien van purge af. Hij overleed 19 December 1775 (Zie XVII).

\section{Oeij Hingko.}

Res. 19 December 1775.

Dezen ochtend overleden zijnde den Capitein der Chineesche natie Ting Ingko: zoo is goedgevonden en verstaan dat ampt weder op te dragen aan den oudsten Lieutenant Oeij Hingko, als daar toe de vereijschte bequaamheid en ontzag bij dat volk hebbende, en de publieke voorstelling van denzelven op een nader te bepalen dag te laaten geschieden naar het voorbeeld van die van zijnen gemelden antecesseur bij het Bataviasch Dagregister deezes jaars aangetekend. 
Bij Res. 23 Aug. 1763 werd de Chinees Oeij Hingko "benoemd tot wijkmeester van de eerste 5 deelen van het blok $O$ in 't Westerveld:"

Hij werd benoemd tot Luitenant bij Res. 19 Febr. 1765.

Major William Thorn - in 1811 met de Britsche expeditie naar Java gekomen - geeft in zijn "Memoir of the Conquest of Java" (1815) op blz. 246 een prent met het onderschrift: Funeral of a Oey Hingko, or Captain of the Chinese at Batavia as drawn on the spot. - Volgens Dr. de Haan is deze plaat, evenals alle andere platen in Thorn's boek, eene copie van een plaat van Rach, die in 1783 is overleden. Kapitein Oeij Hingko overleed in Nov. 1781 (zie XVIII) en de plaat in Thorn'o werk kan alzoo niet eene afbeelding zijn van de begrafenis van dezen Kapitein. Trouwens, van de Chineezen te Batavia zegt de auteur: "Their Captain, Oey Hingko, has several Lieutenants under him, who watch over the Police of that numerous population" maar toen hij dit schreef was Kapitein Oeij Hingko al dertig jaar dood.

Executeuren in zijn boedel waren Oeij Toatko en Luit ${ }^{t}$ Lim Tjoenkong. (Res. 14 Juni 1785 en 11 Juni 1793).

\section{Swa Toenko.}

\section{a. Res. 26 November 1784 .}

In plaats van den deser dagen overleeden Oeij Hingko, Capitain der Chineese Natie, is goedgevonden en verstaan tot Capitain aan te stellen den oudsten Lieutenant dier Natie Swa Toenko, en in steede van denzelven, tot Lieutenant, het Lid in het Collegie van Boedelmeesteren der Chineesche en andere onchristen sterfhuijzen Oeij Biankong, mitsgaders in plaatse van dezen tot Lid in het gemelde Collegie, den Chinees Tan Soeijko.

b. Batavia, 1784 . $1^{\mathrm{e}}$ December.

Mr. Willem Arnold Alting, Gouverneur Generaal, mitsgaders de Raden wegens den Staat der Vereenigde Nederlanden en de Generale Geoctroijeerde Oost Indische Compagnie, allen dengenen die dezen zullen zien of horen lezen Salut, doen te weten:

Nademaal de Capitain der Chineesche natie alhier Oeij Hingko nu onlangs is komen te overlijden en het derhalven nodig is dat weder een ander bequaam en wakker man tot Capitain en Hoofd over de geme natie, worde gesteld, zo is het, dat in Rade van Indië op den 26 der jongstgepasseerde maand November daarover gedelibereerd en gelet zijnde op de beqaamheid en ervarenheid, door eenen dienst van vele jaren in de qualiteit van lieutenant over dezelve natie alhier, bij den Chinees Swa Thoenko verkregen, goedgevonden en verstaan is den gemelden Swa Thoenko te verkiezen en aan te stellen tot Capitain, 
opperhoofd en voorspraak der meergem. Chinesche natie en ingezetenen hier ter plaatse, gelijk wij hem daartoe aanstellen, nomineeren en authoriseeren bij desen, om met en benevens de presende lieutenants dier natie Ong Soeseeng, Iung Pienco, Kokinko, Nio Quanko, Tan Hoelo en Oeij Biamkong, en diegenen die wij in vervolg van tijd in deze of andere qualiteit als hoofden en mede opzigters over die volkeren mogten goedvinden te stellen, de zaken van de gemelde ingezetenen naar behoren en onze orders te manieeren, met even zodanigen magt en authoriteit als zijn predecesseur Oeij Hingko heeft gehad, namelijk om met communicatie zijner lieutenants, alle kleine voorvallende zaken onder de Chinezen alhier uit onzen name af te doen en te beslegten, dog de grote of anderzints dubieuse te renvoijeeren daar 't behoort, mitsgaders verders alles te doen wat een goed, vroom en wakker Capitain, opperhoofd en voorspraak toestaat en betaamt. Ordonneeren en bevelen derhalven alle hoge en lage officieren en specialijk die van den E. geregte dezer stede, den voorschreven Swa Thoenko daarvoor aan te nemen en te erkennen, ook in alle zaken zijn officie rakende behoorlijk te maintineren en voor te staan, wijders aan alle Chinesche ingezetenen hier ter plaatse, zo die thans hier resideren, als die namaals nog zouden mogen aankomen denzelven Swa Thoenko in zijn voorsz. officie alle behoorlijke gehoorsaamheid, eere, hulpe en bijstand toe te brengen en te bewijsen, alzo wij zulks ten dienste van de Generale Compagnie, mitsgaders tot gerief en welstand der gemelde Chinesen alhier, zodanig bevinden te behoren.

Gegeven int Casteel Batavia, op 't eiland Groot Java, int Koningrijk Jaccatra desen eersten December 1784. (Onderstond) Den Gouverneur Generaal van Nederlandsch Indië (was getekend) W. A. Alting. (ter zijde stond) Ter ordonnantie van welgem ${ }^{e}$ hunne HoogEdelheden (was getekend) Jan Greeve. Secrs.

Accordeert, D. D. van Haak, $\mathrm{E}^{\mathrm{e}} \mathrm{kl}$.

Bij Res. 31 Jan. 1775 werd hij benoemd tot Luitenant.

Van Amboina wordt 10 Mei 1771 aan de Regeering te Batavia bericht "dat vermits het vertrek van den gew. Pagter Swa Toenko na Batavia geen lijst geformeert kan worden van de vaartuijgen welke in 1769 en 1770 alhier zijn geweest".

Omdat hij de Chineesche armenschool in het Chineesche hospitaal verwaarloosde, vroegen de Luitenants vergunning tot oprichting van een school buiten de stad, op Klenteng. (Res. 9 Maart 1787). 


\section{Ong Tjoeseeng.}

\section{a. Res. 8 Juni 1790 .}

Mits het overlijden van den Capitain der Chineesche natie alhier Swa Hoenko is wijders nog op de propositie van welgem. $Z$ ijn Ed. goedgevonden en verstaan als zoodanig weder aan te stellen den oudsten Luijtenant dier natie Ong Tjoe Seeng en tot Luijtenant der Chineesche inwoonders alhier Tan Poko.

b. Batavia, 1 Juli 1790.

$M^{r}$. Willem Arnold Alting, Gouverneur Generaal, mitsgaders de Raaden wegens den staat der Vereenigde Nederlanden ende generaale geoctroijeerde Oost-Indische Compagnie, allen dengeenen die deesen zullen zien ofte hooren leesen Salut, doen te weeten:

Nademaal de Capitain der Chineese natie alhier Swa Toenko, nu onlangs is koomen te overlijden en het derhalven nodig is, dat weder een ander bequaam en wakker man tot Capitain en hoofd over de gemelde natie worde gesteld, zoo is het, dat in Raade van Indië, op den $8^{\text {n }}$ jongst gepasseerde maand Junij daarover gedelibereerd en gelet zijnde op de bekwaamheijd en ervaarenheijd, door eenen dienst van veele jaaren [in] de qualiteit van Lieutenant over dezelve natie alhier, bij den Chinees Ong Tjoeseeng verkreegen, goedgevonden en verstaan is, den gemelde Ong Tjoeseeng te verkiesen en aan te stellen tot Capitain, opperhoofd en voorspraak der gemelde Chineesche natie en ingezeetenen hier ter plaatse, gelijk wij hem daartoe aanstellen, nomineeren en authoriseeren bij deesen om, met en beneevens de presente lieutenants dier Natie Tiung Pi Enko, Nio Quanko, Oeij Biankong, Lim Hantam, Oeij Geeko en Tan Poko, en diegeenen die wij in vervolg van tijd in deese of andere qualiteit als hoofden en medeopzigters over die volkeren mogten goedvinden te stellen, de zaaken van de gemelde ingezeetenen naar behooren en onze ordres te manieeren, met even zodanige magt en authoriteit als zijn predecesseur Swa Thoenko heeft gehad, namentlijk, om met communicatie zijner lieutenants, alle kleine voorvallende zaaken onder de Chineezen alhier, uit onzen naam af te doen en te beslegten, dog de groote of anderzints dubieuse te renvoijeeren daar het behoord, mitsgaders verders alles te doen, wat een goed, vroom en wakker Capitain, opperhoofd en voorspraak toestaat en betaamt.

Ordonneeren en beveelen dierhalven alle Hooge en laage Dl. 78. 
officieren en specialijk die van den E. geregte deser steede, den voorschreeven Ong Tjoeseeng daarvoor aan te neemen en te erkennen, ook in alle zaaken, zijn officie raakende, behoorlijk te mainctineeren en voor te staan; wijders aan alle Chineesche ingezeetenen hier ter plaatse, zoo die thans hier resideeren als die namaals noch zouden mogen aankoomen, denzelven Ong Tjoeseeng, in zijn voorschreeven officie alle behoorlijke gehoorzaamheid, eere, hulpe en bijstand toe te brengen en te bewijzen, alsoo wij zulks ten dienste van de generaale compagnie, mitsgaders tot gerief en welstand der gemelde Chineesen, alhier zodanig bevinden te behooren.

(Onderstond:) Gegeeven in het Casteel Batavia op het eijland Groot Java, in het koningrijk Jaccatra deezen eersten Julij 1790. (Lager:) Den gouverneur generaal van Nederlandsch Indië (: was geteekend:) W. A. Alting. (: Ter zijde stond:) 's Comps zegul gedrukt in rood lack (: Daar onder:) Ter ordonnantie van welmelde Hunne Hooge Edelheeden (: was geteekend:) P. G. van Overstraten, Secretaris.

Hij werd benoemd tot Luitenant bij Res. 4 Aug. 1775.

Naar aanleiding van de twisten over de nalatenschap van Luitenant Kokinko (Zie onder Luitenants 54) wiens (xecuteur hij was, beklaagde hij zich bij de Regeering, die bij Res. 3 Moi 1791 verstond: „behalven dat het ook wenschelijk is dat een hoofd van een natie gemaintineerd en beschermd word tegen het disrespectueus, brutaal, seditieus gedrag van den.gedachten Poa Kontong, ter voorkoming van een algemeen wantrouwen en de gevolgen die daaruit te dugten zijn ... den ged. Poa Kontong tot nadere order deeser Regeering op het eiland Edam te plaatsen, om aldaar buiten eenigen arbeid te zijnen kosten te verblijven". Bij Res. 4 Oct. 1791 werd Poa Kontong van zijn bannissement ontslagen.

Zie over hem ook Res. 23 Dec. 1791, 11 Jan. 1792 en 14 Febr. 1792.

Luitenant Gouw Tjangsie (Zie onder Luitenants 62, en XXI) was medeexecuteur in zijn boedel.

\section{Oeij Biankong.}

a. Res. 11 October 1791.

Voorts is op de propositie van den Heer Gouverneur Generaal goedgevonden en verstaan, in steede van den overleeden Capitain der Chineesche Natie alhier Ong Toeseeng, als zodanig weeder aan te stellen den lieutenant dier natie Oeij Biankong, mitsgaders tot Lieutenant den Chineesch Tan Koanko en in zijn plaats tot lid in het Collegie van Boedelmeesteren der Chineesche en andere onchristen sterf huizen, te benoemen de Chinees Tan Peengko. 


\section{b. Batavia, 15 October 1791 .}

$\mathrm{M}^{\mathrm{r}}$ Willem Arnold Alting, Gouverneur Generaal mitsgaders de Raaden weegens den, staat der Vereenigde Nederlanden en de Generale geoctroijeerde Oost Indische Compagnie, allen dengeenen die deeze zullen zien of hooren leezen, Salut, doen te weeten:

Nademaal de Capitain der Chineesche Natie alhier Ong Tjoeseeng nu onlangs is komen te overlijden, en het derhalven noodig is dat weeder een ander bekwaam en wakker man tot Capitain en Hoofd over de gemelde Natie worde gesteld, zo is het dat in Raade van Indië op den 11 deeser maand daarover gedelibereerd en gelet zijnde op de bekwaamheijd en ervaarendheijd door eenen dienst van veele jaaren, in de qualiteijt van Lieutenant over deselve Natie alhier, bij den Chinees Oeij Biankong verkregen, goedgevonden en verstaan is, den gemelde Oei Biankong, te verkiesen en aan te stellen tot Capitain, opperhoofd en voorspraak der gemelde Chineesche natie en ingezeetenen hier ter plaatse, gelijk wij hem daartoe aanstellen, nomineeren en authoriseeren bij deezen, om met en beneevens de presente Lieutenants dier natie Tung Pienko, Nio Quanko, Tan Poko, Lim Tjoenkong, Gouw Tjangsie en Tan Quanko, en diegeenen die wij in vervolg van tijd in deeze of andere qualiteijt als hoofden en meede opzigters over die volkeren mogten goedvinden te stellen, de zaaken van de gemelde ingezeetenen naar behooren en onze orders te manieeren met eevenzodanige magt en authoriteijt als zijn predecesseur Ong Tjoeseeng heeft gehad, namentlijk om met communicatie zijner lieutenants, alle kleine voorvallende zaaken onder de Chirreesen alhier uit onzen naamen af te doen en te beslegten, dog de groote of andersints dubieuse te renvoijeeren daar het behoord, mitsgaders verders alles te doen wat een goed, vroom en wakker Capitain, opperhoofd en voorspraak toestaat en betaamt, Ordonneeren en beveelen dierhalven alle hooge en laage officieren en specialijk die van den E. geregte deezer steede, den voorschreeven Oei Biankong daarvoor aan te neemen en te erkennen, ook in alle saaken zijn officie raakende behoorlijk te mainctineeren en voor te staan, Wijders aan alle Chineese ingezeetenen hier ter plaatse, zo die thans hier resideeren als die namaals nog zouden mogen aankoomen, denselven Oei Biankong in zijn voorschreeven officie alle behoorlijke gehoorzaamheijd, eere, hulpe en bijstand toe te brengen en te bewijzen, also wij zulks ten dienste van de Generale Com- 
pagnie mitsgaders tot gerieff en welstand der gemelde Chineezen alhier, zodanig bevinden te behooren. (Onderstond:) Gegeeven in het Casteel Batavia op het eiland Groot Java, in het koningrijk Jaccatra deezen vijftiende dag van de maand October 1791. (Lager:) Den Gouverneur Generaal van Nederlands India (was geteekend:) W. A. Alting (in margine stond:) 's Comps zegel gedrukt in roode lack (daar onder:) ter ordonnantie van Welm: Hunne Hoog Edelheeden (:was geteekend:) P. van de Weert, Secretaris. Accordeert, Oldenzeel, $E^{e} \mathrm{kl}$. Voor 't nazien, A. J. Köning. Voor 't opleesen, A. L. Ras.

c. Res. 27 Dec. 1800.1

De Capitain der Chineesche Natien Oeij Biankong bij requeste te kennen gegeeven hebbende dat hij in den jaare 1778 aangesteld zijnde tot lid in het collegie van Boedelmeesteren der Chineese en andere onchristen sterfhuisen, vervolgens in 1784 was gevavoriseert met een lieutenants plaats onder de officieren van zijne natie, tot dat deze Regeering hem in 1791 had gelieven te bevorderen tot Capitain der gemelde natie, welke post hij tot nu en dus bijna negen jaaren, zo hij eerbiedig vertrouwden tot haare volkomen satisfactie had waargenomen dat hij in zijne voorschr. verschillende betrekkingen geduurende een tijdperk van meer dan twee en twintig jaaren alle zijne vermogens had te zamen gespannen en vereenigt, ten einde als een nuttig lid van de maatschappij zich van zijne verplichting te kwijten en waar omtrend hij zich dan ook nedrig flatteerde nimmer te zijn te kort geschoten - dat hij nu echter bij het vast aannaderen van den ouderdom en de daar aan verbonden lichaams gebreken en zwakheden ook bereeds tot zijn leedweezen gevo[e]lde voor het dragen deezer moeijelijke en zwaar drukkenden post niet langer geschikt te zijn te meer daar den suppliant bij het afneemen zijner geestvermogens een goed gehoor moest missen en door gebrek van een gezonde ademhaling al vrij dikwijls en veele dagen achtere[e]n in zijne veelvuldige werkzaamheeden gestremt en verhindert wierd - met ootmoedig verzoek uit dien hoofde dat deze Regeering hem het laatste gunstbewijs zoude gelieven te schenken, door hem uit zijn presente post behoudens rang te ontslaan, en te permitteeren de overige dagen van zijn leeven in een stille en hem

1 Landsarchief. 
zo zeer benodigde rust door te brengen, mitsg ${ }^{\text {s }}$ uit consideratie van zijne langjarige diensten en tot een blijk aan zijne natie, van dezelve getrouwelijk en ten genoegen van deeze Regeering waargenomen te hebben, aan zijne zoon Oeij Kamseeng gracieuselijk toe te voegen den titul en rang van oud Boedelmeester. $Z_{o}$ is goedgevonden en verstaan, deeze instantie te accordeeren en mitsdien den gemelden Oeij Biankong als oud Capitain zijner natie het verzogt ontslag te verleenen met den titul en rang van oud Capitain der Chineese natie alhier, doch te declineeren zijn tevens gedaan verzoek dat aan zijn zoon Oeij Kamsing den titul en rang van oud Boedelmeester toegevoegd zoude mogen worden als daar op geen de minste aanspraak hebbende .....

Hij was Boedelmeester van 1 Juni 1778-26 Nov. 1784 en werd benoemd tot Luitenant bij Res. 26 Nov. 1784.

Hij overleed tusschen 17 Dec. 1802 en 22 Maart 1803 (Mededeeling Dr. de Haan).

Zijne weduwe was Hantjetnio (Res. 21 Dec. 1792).

\section{Gouw Tjangsie.}

a. Res. 27 December 1800 .

En is wijders goedgevonden en verstaan in steede van den gemelde Oeij Biankong weder tot Capitain der voornoemde Natie te laten optreeden den oudsten Lieutenant Chinees Gouw Tjangsie en in plaats van de voornoemden Nio Guanko tot Lieutenant der gemelde Natie aan te stellen den Chinees en oud Lid in het collegie van Boedelmeesteren der Chineeschen en andere onchristen sterfhuisen Tan Soeijko.

b. Geinsereerd in de Res. der H. Regeering van 26 October 1809.1

Batavia den 20 October 1809.

Is besloten, den Kapitein der Chinezen Gouw Tjansie, uithoofde van verregaand wangedrag en het niet behoorlijk waarnemend ${ }^{2}$ van zijnen post, in die qualiteit te demitteren. En zal hier van kennis worden gegeven aan President en schepenen van

${ }^{1}$ Landsarchief.

${ }^{2}$ sic. Vgl. Priangan, I, bl. XV. 
Batavia, om zulks ter kennisse te brengen van die geenen wie het aangaat, als mede aan den voorm. Gouw Tjansie tot informatie en narigt.

(Onderstond) Accordeert met voorschr: Register (Was getekend) H. Veeckens sec:

Hij werd benoemd tot Luitenant bij Res. 8 Febr. 1791.

\section{Tan Peengko.}

Batavia den 20 October 1809.

Is besloten, aan te stellen tot Kapitein en Hoofd der Chinezen te Batavia en dies ommelanden, den Luitenant der Chinezen Tan Peenko en zulks in plaats van de gedemitteerde Kapitein Gouw Tjansie.

En zal hier van kennis worden gegeven aan President en schepenen van Batavia, het collegie van Boedelmeesteren der Chineeze en andere onchristen sterfhuizen en den benoemden Kapitein der Chinesen Tan Peengko, respective tot naricht en informatie.

(Onderstond) Accordeert met voorschr. Register (Was getekend) H. Veeckens sec.

$\mathrm{Na}$ bij Res. 11 Oct. 1791 te zijn benoemd tot Boedelmeester werd hij tot Luitenant aangesteld bij Res. van 13 Nov. 1792. 


\section{LUITENANTS \\ (1678-1809)}




\begin{tabular}{|c|c|c|c|c|c|c|c|c|c|c|c|}
\hline & \multirow{3}{*}{$\begin{array}{l}\text { Naam in de } \\
\text { resolutie van benoeming }\end{array}$} & \multirow{3}{*}{ Chineesche naam } & & \multicolumn{7}{|c|}{ Into benoeming } & \multirow{3}{*}{ Gouverneur-Generaal } \\
\hline & & & \multirow{2}{*}{ Europeesche } & \multicolumn{7}{|c|}{ Chineesche } & \\
\hline & & & & yyclusjar & & Periode & & Jaar & Maand & Dag & \\
\hline I & Lim Si Say & 林 & I4 Juni 1678 & 伐午 & 康熙 & Khon & g $\mathrm{Hi}$ & I7 & 4 & 26 & van Goens \\
\hline 2 & Li Tsoeko & 李 & I6 Mei I679 & 己末 & $n$ & & " & I8 & 3 & 26 & $n$ \\
\hline 3 & Oeij Koeko & 黃 & I 2 Januari 1682 & 辛西 & $n$ & & $n$ & 20 & I 2 & 4 & Speelman \\
\hline 4 & Que Pauko & 享 & 3 Augustus I68; & 乙丑 & $n$ & & $\eta$ & 24 & 7 & 4 & Camphuijs \\
\hline 5 & $\operatorname{Lim} \operatorname{Kee}(\mathrm{n}) \mathrm{ko}$ & 林敬哥 & 4 Augustus $168 ;$ & 乙井 & 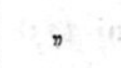 & & ” & 24 & 7 & 5 & n \\
\hline 6 & Ong Gouko & 王 & 26 Maart I694 & 用戊 & $n$ & & $n$ & 33 & 3 & I & van Outhoorn \\
\hline 7 & Que Kiauko & 郭 & Io Juni 1695 & 乙亥 & $n$ & & $n$ & 34 & 4 & 29 & $\pi$ \\
\hline 8 & Tambocco & 陳 穆哥 & I6 Juni I702 & 壬午 & 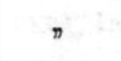 & & " & $4 \mathrm{I}$ & 5 & $2 \mathrm{I}$ & $n$ \\
\hline 9 & Que Hoenko & 郭訓哥 & 5 Mei 1705 & 乙酉 & $n$ & & $n$ & 44 & 4 & I3 & van Hoorn \\
\hline IO & Lie Joncko & 李容哥 & 5 Mei 1705 & 乙酉 & $n$ & & $\eta$ & 44 & 4 & I3 & $n$ \\
\hline I I & Ho Lienko & 何蓮哥 & Io Juni I 707 & 厂亥 & $n$ & & $n$ & 46 & 5 & I I & $n$ \\
\hline I 2 & Lim Tsoenko & 林春哥 & 28 Juni 1720 & 庚子 & $n$ & & $\eta$ & 59 & 5 & 23 & Zwaardecroon \\
\hline I 3 & Lim Somko & 林森哥 & 28 Juni 1720 & 庆子 & 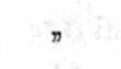 & & 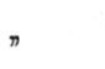 & 59 & 5 & 23 & $n$ \\
\hline I 4 & Tan Eengkong & 陳榮公 & 28 December 1725 & 浓已 & 雍正 & Jong & Tsing & 3 & I I & 24 & de Haan \\
\hline I 5 & Tan Tionqua & 陳忠官 & 28 December 1725 & ;飞已 & 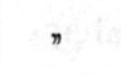 & & " & 3 & I I & 24 & ” \\
\hline I6 & Nilocko & 連淥哥 & 8 Juli 1729 & 西 & $n$ & & $n$ & 7 & 6 & I 3 & Durven \\
\hline I 7 & Ongeengsaij & 王應使 & 8 Juli 1729 & 已西 & $n$ & & $n$ & 7 & 6 & I 3 & n \\
\hline I 8 & Io Seenkong & 楊成光 & 21 October 11729 & 已西 & " & & $\eta$ & 7 & 8 & 29 & n \\
\hline I9 & Ni Hoekong & 連褔公 & 6 Februari 1733 & 世子 & 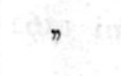 & & $\pi$ & Io & 12 & 22 & van Cloon \\
\hline 20 & Li Hoko & 李和哥 & 23 Juni 1733 & & $n$ & & " & owl lba & from & I I $28 \mathrm{me}$ & $\begin{array}{r}\text { 26/2023 12:19:10pM } \\
\text { via free access }\end{array}$ \\
\hline
\end{tabular}




\begin{tabular}{|c|c|c|c|c|c|c|c|c|c|c|}
\hline & \multirow{3}{*}{$\begin{array}{l}\text { Naam in de } \\
\text { resolutie van benoeming }\end{array}$} & \multirow{3}{*}{ Chineesche naam } & \multirow{3}{*}{ Europeesche } & \multicolumn{6}{|c|}{ an benoeming } & \multirow{3}{*}{ Gouverneur-Generaal } \\
\hline & & & & \multicolumn{6}{|c|}{ Chineesche } & \\
\hline & & & & Cyclusjaar & & Periode & Jaar & Maand & Dag & \\
\hline $2 \mathrm{I}$ & Que Oeijko & 郭威 哥 & I2 Maart I734 & 甲寅 & 䔨正 & Jong Tsing & I 2 & 2 & 8 & van Cloon \\
\hline 22 & Nio Kanko & 楊簡哥 & 3I December 173 & 甲寅 & n & " & I 2 & I 2 & 7 & $n$ \\
\hline 23 & Oeij Tsomko & 黃箴哥 & 28 September $17 /$ & 丙辰 & 乾 隆 & Khian Liong & I & 8 & 24 & Patras \\
\hline 24 & Kou Tsinqua & 許進官 & $27 \mathrm{Mei}$ I738 & 戊 午 & $n$ & $"$ & 3 & 4 & 20 & Valckenier \\
\hline 25 & $\mathrm{Ni}$ Tonqua & 連鐘官 & I 3 Juni $173^{8}$ & 戊 午 & $n$ & " & 3 & 5 & 8 & ” \\
\hline 26 & Oeij Theeko & 黄提哥 & 26 Januari 1740 & 己末 & 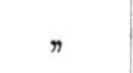 & $n$ & 4 & I 2 & 28 & $n$ \\
\hline 27 & Oeij Tsomko & 黄筬哥 & 28 Juni I 743 & 癸亥 & 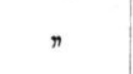 & $n$ & 8 & 5 & 7 & van Imhoff \\
\hline 28 & Tan Iko & 陳怡哥 & 28 Juni I 743 & 癸亥 & $n$ & 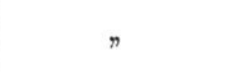 & 8 & 5 & 7 & " \\
\hline 29 & Lim Kocko & 林 國哥 & 7 Mei I 745 & 乙开 & $n$ & $n$ & 10 & 4 & 6 & $n$ \\
\hline 30 & Tsou Tsoen Seeng & 䔡俊生 & 2 I April I 747 & 丁卯 & $n$ & r & I 2 & 3 & I 2 & $n$ \\
\hline $3 I$ & Tang Wang Seeng & 陳遠生 & Io December $1 \mathrm{I} / 4$ & 戊辰 & $n$ & $n$ & I 3 & IO & 20 & $"$ \\
\hline 32 & Oeij Tsilauw & 黄市閙 & IO December 1174 & 成辰 & $n$ & $n$ & I 3 & 10 & 20 & $n$ \\
\hline 33 & Lim Tjipko & 林緝哥 & 3 Juni I749 & 己 巳 & . & n & I 4 & 4 & I9 & $n$ \\
\hline 34 & Ong Eng Saaij & 王榮 使 & 29 December $117 ;$ & & $n$ & $n$ & I 5 & 12 & I & Mossel \\
\hline 35 & Lim Ki-Enko & 林健哥 & I 5 Juni I75 I & & $n$ & $n$ & I6 & 5 & 22 & $n$ \\
\hline 36 & Lim Theecko & 林鉸哥 & 8 November $17 \%$ & 用戌 & ” & $n$ & 19 & IO & 5 & $n$ \\
\hline 37 & Khouw Hong Liang & 許芳艮 & 27 Augustus $1 ; 75^{\circ}$ & 丙子 & $n$ & 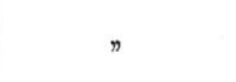 & $2 \mathrm{I}$ & 8 & 2 & $n$ \\
\hline $3^{8}$ & Thee Poanko & 戴弁哥 & I8 December $117 \%$ & 己卯 & $n$ & $n$ & 24 & 10 & 29 & $\eta$ \\
\hline 39 & Khouw Tjangko & 許骤召召 & Io Juni I762 & & $n$ & $"$ & 27 & 5 & I 8 & van der Parra \\
\hline 40 & Louw Nungko & 盧郎哥 & Io Juni 1762 & 王午 & $n$ & $n$ & I2Zadded & & $\begin{array}{l}\text { I } 8 \\
\text { come4/ }\end{array}$ & $\begin{array}{l}\text { /2023 } 12: 19 \text { m } 10 \mathrm{PM} \\
\text { via free access }\end{array}$ \\
\hline
\end{tabular}




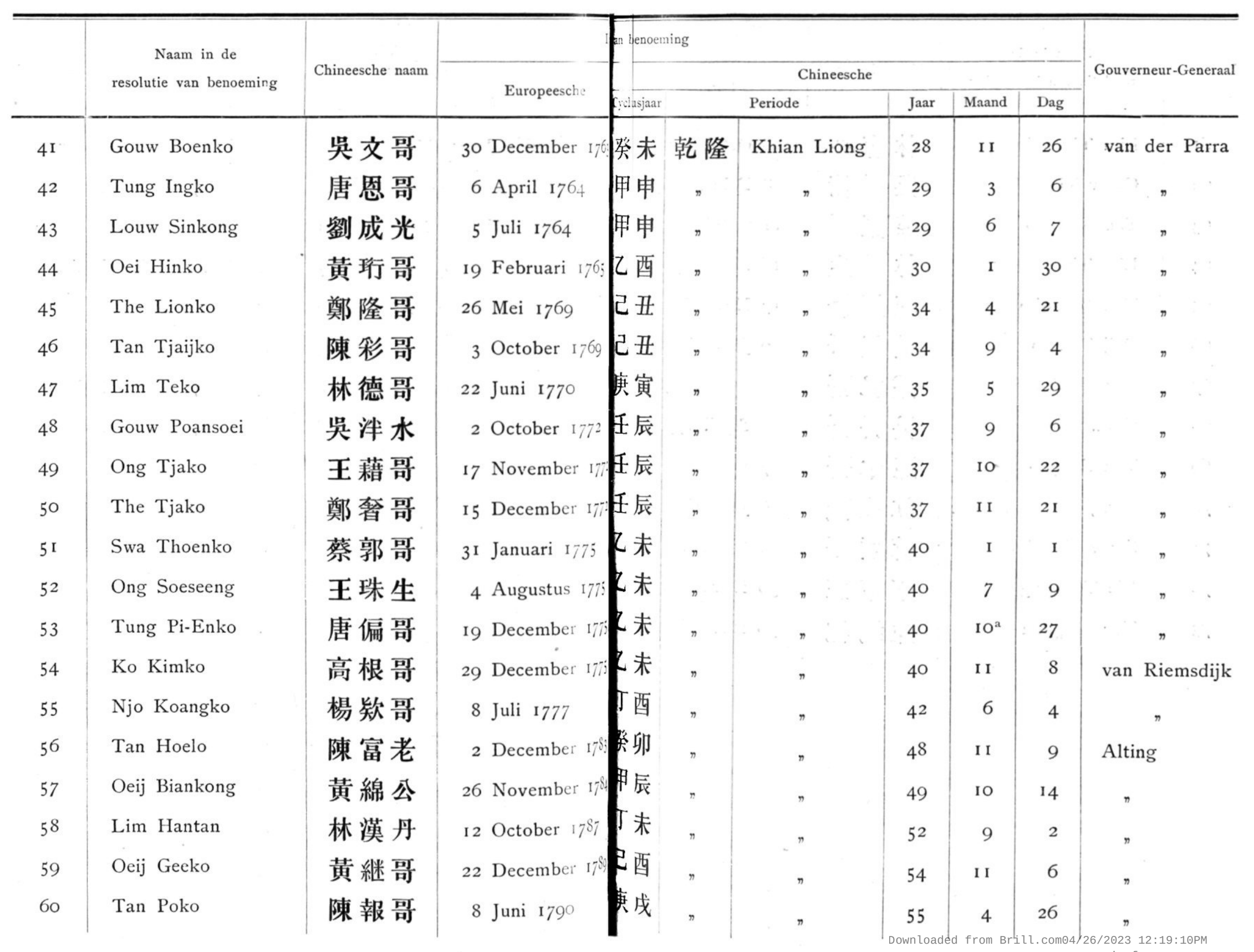




\begin{tabular}{|c|c|c|c|c|c|c|c|c|c|c|}
\hline & \multirow{3}{*}{$\begin{array}{l}\text { Naam in de } \\
\text { resolutie van benoeming }\end{array}$} & \multirow{3}{*}{ Chineesche naam } & & \multicolumn{6}{|c|}{ benoeming } & \multirow{3}{*}{ Gouverneur-Generaal } \\
\hline & & & \multirow{2}{*}{ Europeesche } & \multicolumn{6}{|c|}{ Chineesche } & \\
\hline & & & & clusjaar & & Periode & Jaar & Maand & Dag & \\
\hline $6 \mathrm{I}$ & Lim Tjoengkong & 林春公 & 26 October 1790 & 知戌 & 乾 隆 & Khian Liong & 55 & 9 & 19 & Alting \\
\hline 62 & Gouw Tjangsie & 吳纉緒 & 8 Februari ${ }^{1} 791$ & 亥 & " & " & 56 & I & 6 & 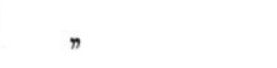 \\
\hline 63 & Tan Koanko & 陳寛哥 & II October I791 & 亥 & $"$ & $n$ & 56 & 9 & I4 & $n$ \\
\hline 64 & Lim Tiangseeng & 林長生 & I6 Maart I 792 & 子 & r & " & 57 & 2 & 24 & " \\
\hline 65 & Tan Peengko & 陳炳哥 & I 3 November 179 & 子 & " & " & 57 & 9 & 29 & $n$ \\
\hline 66 & Oeij Tamko & 黄董哥 & 9 Januari 1795 & 寅 & $n$ & , & 59 & I 2 & I9 & " \\
\hline 67 & Tee Honko & 戴弘哥 & 1795 & & & & & & & n \\
\hline 68 & Gouw Kocko & 吳科哥 & 20 April $179^{8}$ & 午 & 嘉慶 & Ka Khing & 3 & 3 & 5 & van Overstraten \\
\hline 69 & Tan Soeijko & 陳水哥 & 27 December I800 & 电 & $n$ & $n$ & 5 & II & 12 & $n$ \\
\hline 70 & Kang Phoboen & 江波絞 & 6 Januari $\mathrm{r} 80 \mathrm{I}$ & 电申 & $\pi$ & $n$ & 5 & II & 22 & $n$ \\
\hline $7 \mathrm{I}$ & Souw Kongko & 蘇 廣哥 & 26 October 1809 & e & " & $\pi$ & I4 & 9 & I 8 & Daendels \\
\hline 72 & Lie Tongong & 李東旺 & 30 November I 800 & 巳 & $n$ & 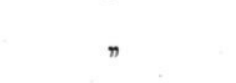 & I4 & IO & 23 & $n$ \\
\hline 73 & Tan Mappan & 陳媽抱 & 30 November 180 & 巳 & $"$ & & I4 & IO & 23 & 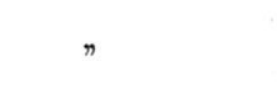 \\
\hline
\end{tabular}




\section{Lim Si Say.}

Voor zijne benoeming zie $\mathrm{V} a$ en $b$.

Vermoedelijk is hij de Boedelmeester geweest die als zoodanig werd aangesteld onder den naam van Limsidsaij in 1674, van Limgisaij in 1676 en van Limsihaeij in 1677.

Bij Res. 17 Oct. 1678 werd ${ }_{n}$ de pacht van het toppen en spelen der Chinesen deser stede" gegund aan den Chinees 'tSio Iisaij, gelijk Luitenant Lim Si Saij ook wordt genoemd in Res. 16 Mei 1679 (zie 2 hierachter) en waarbij aan eene verschrijving moet worden gedacht. Hij overleed in Sept. 1678 (zie onder 2).

\section{Li Tsoeko.}

Res. 16 Mei 1679.

Vermits den luijtenant der Chinese natie deser stede $\mathrm{tSi}$ IJisaij ${ }^{1}$ in September voorleden jaar is comen te overlijden en ons sedert dien tijd al diverse maelen en nu op nieuw eenige versoeken en requesten van vele Chinese ingesetenen zijn te vooren gekomen dat voors. plaatse weder door ons mogt werden gevult en waertoe verscheijde der voornaamste Chinesen bij hun sijn voorgestelt, soo is als nu op 't voordraegen van zijn $\mathrm{Ed} \mathrm{d}^{t}$ (daer op gedilibereert zijnde) verstaen in de voors. luijtenantsplaatse der Chinesen te dezer stede te laten optreden den presenten vaandrigh Litsoeko ende in sijn stede tot vaandrigh dier natie wederom aan te stellen den Chineesen coopman Tsoa Tengelau, hebbende al een lange reex van jaaren alhier geresideert.

Litsoeko was Boedelmeester in 1664 (Vgl. de Haan, Priangan II, 412), in $1665,1668,1669,1673,1674,1677$ en 1678.

De Bataviasche weduwe van Kapitein So Bing Kong benoemde hem tot voogd van diens minderjarigen kleinzoon Souw Go Equa, haren erfgenaam, wien zij een huwelijk voorschreef met Tsionio, dochter van dezen Luitenant. (Zie Bijdr. Kon. Inst. deel 73 bl. 409).

1 Vgl. Dagr. 1679 bl. 187 „Tsoa Yizay"; 
Hij overleed tusschen 20 Nov. 1680, toen hij zijn testament maakte (Res. 30 Dec. 1695) en 12 Jan. 1682 (zie 3a). Zijn graf is het nog bestaande naast dat van Kapitein So Bing Kong.

Bij Res. 14 Juni 1686 werd op verzoek van zijne weduwe (Tanhiamtse ef. Res. 30 Dec. 1695) aan twee van hare dochters transport verleend op een van Compagnie's schepen naar Hoktsioe (Foochow, de hoofdplaats der provincie Hokkian, waar de Compagnie een comptoir had) „om aldaar met meerder zekerheid ten besten opgevoed te kunnen worden". Aan deze weduwe werd bij Rев. 3 April 1699 de oprichting van een steen. bakkerij toegestaan aan de rivier Crocot en bij Res. 20 Juni 1713 om eene van haar suikermolens op haar land aan de oostkust der spruit Tjantiga te laten verplaatsen omtrent de spruit Assam. Zij werd in 1722 begraven naast So Bing Kong's weduwe Njai Inqua.

${ }_{n}$ De Chineese kooplieden Litsoeko en Gantenqua [zoon van Kapitein Siqua, zie onder IV] versoeck doende omme tot cultiveeringe harer suycker plantagien (zijnde wel van de voornaamste deser steede) aan of ontrent de fortresse Anckee eenig meerder lant... in eigendom ... te mogen hebben." (Res. 8 Aug. 1679).

\section{Oeij Koeko.}

a. Res. 12 Januarij 1682 .

Sijn Edelheijt nogh eijndelijcken voorbrengende een requeste van veele der voornaamste Chinesen te deser stede waarbij door haar versocht wert dat de vacante luijtenants chergie van die haarer natie alhier jongst bij den overleden Lietsoeko bedient, als nu weder mochte gesuppleert werden en daartoe sij ernstigh waren recommanderende den Chinees Oeijkoeko geweșen capitein hunner natie op Macassar en oock jongst affgegane boedelmeester der Chinese sterffhuijsen alhier, en een man na 't schijnt van goede getuijgenisse en van wiens trouwherticheijt tot de Compagnie voor desen al preuven gesien sijn.

Zoo is daerop nae deliberatie verstaen denselven Oeijkoeko daertoe bij desen te verkiesen en als luijtenant der Chinese natie te deser stede te creeren te meer dewijle onzen tegenwoordige capiteijn Tsoa Wanjok ook al vrij wat out begint te worden en dierhalven wel een goede adsistentie van een luijtenant van nooden heeft en bij alle ongelegentheijd tot eijgen gerieff en gemak zal dienen.

b. Res. 16 Januari 1682 .

Tonser vergadering van den $12^{\mathrm{n}}$ deser den Chinesen gewesen boedelmeester Oeijkoeko verkooren zijnde tot Luijtenant der ChiDl. 78. 
nesen zoo zeijde Sijn Edelh ${ }^{t}$ ter deser vergadering tot authorisatie van denselven in die bediening tegens morgen de noodige ordre gestelt te hebben en dewijle hetselve als een borgerlijcke zaake door den Heer President van Schepenen diende te geschieden, dat overzulx dan wel vereijschte gem $^{\text {ten }}$ Sijn Ed. (namentlijck d' Heere Hurdt) ook verzelt wierde met eenige aansienlijcke gecommitteerden.

Zulx daar toe dan nogh verder als, nu genomineert zijn den heere Fredrik Bent onsen collega als Ontvanger Generaal,

Item d' ${ }^{\text {re }}$ Bailluw,

de beijde heeren Landdrosten,

de $\mathrm{h}^{\mathrm{r}}$ Sabandhaar Ockersz.,

twee heeren Schepenen en

den Secretaris van 't zelve Collegie.

Hij werd bij Res. 25 Febr. 1679 aangesteld tot Boedelmeester en bleet dit in 1680 en 1681.

\section{Que Pauko.}

Voot zijne benoeming, zie VI.

Quepauqua, handelaar, kwam van de kust van China over Japan in het begin van het jaar 1679 te Batavia (Res. 23 Mei 1679).

Hij werd bij Res. 2 Juni 1685 en 31 Mei 1686 verkozen tot Boedelmeester.

Uit Res. 1 April 1692 blijkt dat Luitenant Que Pauqua toen in een crimineele gijzeling was gedetineerd „over het aanmatigen van 2000 rds. die hij voor reeckening van een ander an den boedel van $\mathrm{Hr}$. Speelman zaliger moste betalen". Hij had de hulp van de Regeering ingeroepen tegen zijnen debiteur Demang Raxa di Bengala ${ }_{n}$ nu van Cheribon overgekomen zijnde" (Res. 19 Nov. 1688) maar werd naar de Justitie verwezen (Res. 26 Nov. 1688). (Zie ook Res. 28 Juni 1689).

Hij nam de vlucht (Res. 23 Juni 1693) en sloot zich te Semarang aan bij oproerige landgenooten die deze stad aan den Soesoehoenan wilden overleveren. Hij werd door dezen Vorst aan de Compagnie uitgeleverd en den $1^{\text {*n }}$ Sept. 1693 te Japara geradbraakt. (Gen. Missive 8 Dec. 1693, zie ook Kol. Archief No. 1429 fol $^{\text {s }} 177,215$ en 216).

\section{Limkeeko.}

Res. 4 Augusti 1685.

Waerop dan d' heer Gouv ${ }^{r}$ Generael geproponeert hebbende of het niet goet ende nootsakel. soude sijn hem nog een tweeden 
lieutenant bij te voegen, om de saken der Chinesen welckers getal al groot is, te bequamelijcker te kunnen hanthaven, ende oock bij nadere te doene ontslaginge van desen Capitain een ander in desselfs plaetse te doen optreden, verstaen is hetselve geen ondienstiglijke sake te sijn ende gevolgel. op de nadere gedane omvrage hier toe ende als tweede Lieutenant aen te stellen den Chinesen boedel $\mathrm{m}^{r}$ Limkeeko alias Jacob.

Dit is het slot van de resolutie, waarvan het begin staat onder VIb bl. (32). Hij werd tot Boedelmeester verkozen bij Res. 6 Juni 1683 en 6 Juni 1684 .

Bij Res. 4 Dec. 1699 werd hem toegestaan het oprichten van twee suikermolens op zijn land Camiri, gelegen ongeveer zes mijlen opwaarts aan de Groote rivier.

\section{Ong Gouko.}

a. Re.s. 26 Maart 1694 .

Verscheijde welgestelde Chinese klede-verkopers, winkeliers en andere handelaers te deser stede woonagtig, mitsgaders de anachodas der aangecomen jonken uijt China, versoek gedaen hebbende dat den Chinees Ong Gouko tot haren tweede luijten ${ }^{t}$ alhier op Batavia, mits de plaetse van Que pauqua door sijn vlugt naer de Oostcust van Java ende executie van sijn persoon op Japara om het gepleegde oproer tot Samarang, vacant geworden was, mogte aangestelt werden, soo is daerover als nu gedelibereert en vervolgens in agtinge genomen sijnde dat de onpasselijkheijt van den $\mathrm{Capt}^{\mathrm{n}}$ der Chinesen de vervullinge dier plaetse te meer presseert, en ook desen Ong Gouko een man van goede gerugte $\mathrm{zij}$, die wel 50 jaeren lang alhier domicilie gehouden en tweemalen het ampt van boedelmeester bekleet heeft, ${ }^{1}$ soo is goetgevonden deselve tot tweede luijtenant naest den Luijtenant Limkeenko alias Jacob bij desen te verkiesen en aan te stellen.

b. Res. 31 Maart 1694.

Den Chinees Ong Gouko op den $26^{\text {en }}$ deser tot $2^{\text {den }}$ luijtenant der Chinesen aangestelt sijnde, is als nu verstaan deselve op

1 In de jaren 1689 en 1690, en in de jaren 1692 en 1693 (Res. 3 Juni 1689, 2 Juni 1690, 6 Juni 1692 en 6 Juni 1693). 
aanstaande dingsdag den $6^{\text {en }}$ April door den ordinarij Raad en President van Heeren Schepenen $\mathbf{M}^{\mathrm{r}}$. Abraham van Riebeek geadsisteert met den bailliuw Davit Dispontijn, den Landdrost Henrij de Boullan en den Sabandar Gerard van de Voorde benevens twee gecommitteerde Schepenen en de gesworen Clercq van geseijde Collegie, in het huijs van den $\mathrm{Cap}^{\mathrm{n}}$ der Chinesen genaemt Quekeenqua te doen voorstellen in deselve sijne qualiteijt, voor soo veele toekijkeren als door gommeslag bij den anderen sullen verschijnen.

Hij vertrok naar China (zie onder $8 a$ ).

\section{Que Kiauko.}

Voor zijne benoeming zie VII.

Res. 15 Juni 1703.

Het berigt van den Secretaris der heeren Schepenen nopende de Chinese sollicitanten die hier gaarne soude willen blijven sijnde ingebragt en gelesen waarvan bij resolutie de dato $8^{\text {on }}$ deser gemelt word, so is g'arresteert geworden het gelicentieerde getal van 50 stx te laten als volgt namentlijek

den Capitain Limkeenko . . . . . . . . . . . . . coppen 10

voor den ouden Capitain Koenko . . . . . . . . . . ” 8

2 luijtenants als Tamboko en voor reek. van Kiauko die

na China een tochtje is gaan doen, ijder 6 coppen . . . . . . 12

4 boedelmeesters Pausaqua, Lijonko, Tio Inio en Bepequa

elk vijf. . . . . . . . . . . . . . . . . . . . . $\quad$ " 20

te samen als voren . . $\overline{\text { coppen } 50}$

${ }_{n} \mathrm{Op}$ 't versoek van den Luijtenant der Chinezen Que kiauko is verstaan denselven op zijne anstaande voyagie na China met 150 picols thin te laten gerieven tegen $15 \frac{3}{4}$ rds. 't picol van 125' (Res. 19 Mei 1702).

Zijne weduwe was Tsieuw Kitse die 5 Nov. 1732 een testament makte.

Als zijne dochters worden genoemd Keengnio, Laynio en Tsionio (Res. 4 Dec. 1744).

\section{Tambocco.}

a. Res. 16 Juni 1702 .

Tot lieutenant over de Chinese natie alhier is uijt degenen die daertoe haer dienst gepresenteert hebben en voor dewelke door verscheijden annachodas en Chinese ingesetenen deser 
stede bij requesten versoeck gedaan zij in plaatse van den geweesen Lieutenant Ongouqua die op sijn gedane instantie en ons gedragen consent met er woon na China is vertrocken, goetgevonden en verstaan weder aan te stellen den Chinees Tambocco altans Capitain over die natie tot Chirrebon als eene der bequaamste daartoe geoordeelt sijnde.

\section{b. Res. 26 Februarij 1692 .}

Dewijle den sabandaer op Chirbon met name radja negara overleden is ende verkiesinge van een ander volgens de contracten met de princen gebroeders de Comp ${ }^{e}$ competeert, soo is goedgevonden die vacante plaetse te vullen met den Cap ${ }^{n}$ der Chinesen aldaer genaemt Aria Martanata als degene sijnde die daer toe al in den jare 1688 door den Oppercoopman Joannes de Hartogh voorgedragen is geworden.

c. Res. 2 Augustus 1697 .

In plaatse van den overleden geschoren Chinees Kiay aria martanata geweest sijnde Sabandhar en hooft van die van sijne natie tot Sirrebon, is goetgevonden daer toe weder aan te stellen en derwaerts te senden den Chinees Tamboko aangesien de E. Comp. tot het vervullinge van die plaatse bij het contract tusschen deselve en de Sirrebonse princen van den $8^{\mathrm{n}}$ September 1688 art. 18 en 19 is gequalificeert.

d. Res. $15 \mathrm{Juni} 1703$.

Den Chinees Tamboko tweede luijtenant van die natie alhier, sijnde met eenen daarvan Capitain tot Cheribon, bij request versoekende van den laasten dienst te mogen werden ontslagen, is hem daartoe licentie gegeven en met eenen vergunt daarvan transport te mogen doen aan den Chinees Tansjauko die daartoe aangestelt werd, hebbende den dienst sedert Junij het voorleden jaar dat gem. Tamboko hier tot luijtenant is aangestelt geweest bij provisie en bevorens bij 't leven van den Kiay Area Marta Nata, mede Capitain van die natie tot Cheribon voorsz. geweest zijnde, gedurende desselfs verblijf alhier eenige jaren bevorens ten genoegen waargenomen.

Zie over hem onder VIII.

Zijn zoon was Tantionqua, zie onder 15 . 


\section{9 en 10. Que Hoenko en Lie Joncko.}

a. Res. 5 Mei 1705 .

Door diverse Chinese ingesetenen alhier versoek gedaan sijnde om de Luijtenantsplaatse der Chinese natie instede van den $A^{\circ}$ 1702 naar China vertrockene luijtenant Quekiauko, soo is goedgevonden den Chinees Quehoenko in sijn plaatse, mitsgaders nog bovendien tot een $3^{\text {n }}$ luijtenant dier natie aan te stellen den presenten boedelmeester Lie-Joncko.

\section{b. Res. 15 Februari 1697.}

Is goetgevonden op het daartoe gedaan versoeck tot sabandhaar op Semarang aan te stellen en te laten optreden den Chinees Hoenko dewelcke die plaets alrede ongeveer drij jaren ofte zedert het vertreck ende absentie van den gew. sabandhar en presenten tweden luijtenant van die natie te deser stede Kiauko ten genoegen medegenomen heeft.

c. Res. 20 Dec. 1726 .

Werd verstaan den lieutenant der Chineese natie Lijongqua op sijn versoek om sijnen hogen ouderdom en continueele indispositie van dat ampt te ontslaan en vooreersd geen ander in sijne plaatse te verkiesen, ter zake op den $28^{\text {n }}$ December des voorleden jaars door een supernumeraire aanstelling van 2 diergelijke officieren ter adsistentie van den capitain het getal van die luijden van 3 tot 5 is vermeerderd om de wille der siekte van hem Lijongqua en nog eenen anderen Chinees in name Limsoenko. ${ }^{1}$

(Quehoenko). Res. 18 Nov. 1698 „behelsende notificatie van verscheijde onbetamelijcke bedrijven dewelke door den Sabandhar tot Samarang den Chinees Hoenko souden wesen en nog werden gepleegt, soo is verstaan de vereijste inqueste daerop te laten geschieden."

Ten dienste van zijn jacht werd hij geriefd met trossen en een anker (Res. 13 Mei 1712).

Tot defensie van hun jonk werden aan hem en Luitenant Holienqua 6 stukjes ijzer canon toegestaan.

(Lie Joncko). Hij was Boedelmeester in 1700, 1701 on 1704. Bij Res. 1 Dec. 1713 kreeg hij vergunning een vaartuig naar Banjermasing te zenden mits hij al den daarin geladen peper aan de Compagnie leverde tegen den gewonen prijs van vijf rds. het pikol.

1 Limtsoenko. Zie onder 14 en 15. 
Bij Rez. 18 Maart 1710 werden hem 8 ijzeren stukjes van 250 pond ieder, 150 kogels en $1 \frac{1}{2}$ pikol buskruit, tegen betaling, toegestaan.

Blijkens Res. 5 Oct. 1734 was hij toen overleden, nalatende de zoons Lie Jo Enko, Lie Hongko en Lie Sienko.

\section{Ho Lienko.}

Res. 10 Juni 1707.

Te deser occasie door den heere Gouverneur Generael gesproken zijnde van de vacante luijtenants plaats der Chineesen door de optredinge van Tambocqua tot Capitain en daarop in aanmerkinge genomen wesende de versoeken door de aanwesende Chineese annachodas en diverse voornaamste ingesetenen dier natie alhier dat daartoe mogte werden verkoren eene van de boedelmeesters Ho-li-enko, Goeijhoeijkong off Tanlianko danwel den doctor Thibitia ofte den coopman Tanjukong; Soo is op Sijn Edelheijts omvrage verstaen tot de voorsz. qualiteit van luijtenant aantestellen den eerstgen. jongstafgegane boedelmeester Ho-li-enko.

Hij werd bij Res. van 5 Juni 1705 en 4 Juni 1706 benoemd tot Boedelmeester onder den naam van Gouw lienko.

Bij Res. 10 Juni 1707 werd hem voor twintig jaren vergunning verleend om twee suikermolens op te richten op Pamanoekan en Tjassem. Hij bezat daar ook een houtzagerij en een kalkbranderij (Res. 25 Nov. 1707, 4 Febr. en 30 Maart 1708).

Door den Gouv. Generaal werd overgegeven een relaas nuit de mond van den Chinees luijtenant Holienko van wegens het voorgevallene op Banjermassing tusschen d'Engelsen ende den Inlander aldaar, twelk verstaan is int Bataviase dagregister to insereren. (Res. 12 Aug. 1707).

Bij Res. 20 Aug. 1709 werd hem toegestaan ontslag van de licentie tot het oprichten van houtzagerijen en suikermolens op Pamanoekan en Tjassem „om de traversen en onwilligheid der Javanen".

\section{2 en 13. Limtsoenko en Limsomko.}

Rés. 28 Juni 1720.

Voorts nog gesproken zijnde over de vervulling der vacante lieutenantsplaatsen over de Chineesen is, ten aanzien den lieutenant Lijongqua nog maar alleen overig blijft, en reets bejaart en genoegsaam aff is, goedgevonden het getal derselve weder te brengen op drie gelijk het nog jongst is geweest voor de dood 
van den lieutenant Que Hoenqua en is daarop al verder verstaan uijt degeene die daarom versoek hebben gedaan tot lieutenants aan te stellen de oud boedelmeesters Limtsoenko en Limsomko.

Lim Tsoenko was de schoonvader van Kapitein Ni Hoekong (XI) en overleed vóór 12 Maart 1734 (zie onder 21). Hij was Boedelmeester in 1718 en 1719.

Op het verzoek van Limsomko om te mogen worden gequalificeerd ntot het vervolgen en aantasten van zoodanige schelmen en vagebonden als hem sedert eenigen tijd in zijn tuin en wooning gelegen aan de rivier Crocot, zoo met het werpen van steenen als het openbreken van de ompaggering en andersints, insonderheid des nachts, quamen te molesteeren, zooals dat bij eene overgelegde notariale attestatie werd bevestigd" werd besloten dit te accordeeren „onder permissie om zoodanige knaapen, als gewoonlijk van wapen voorsien, met scherp te keer te mogen gaan en selvs te vervolgen op de landen en erven sijner naastgelegen buuren mits daaromtrent gebruijkende de vereijste voorsigtigheid tot voorkoming van ongelucken. (Res. 22 Aug. 1727).

Bij Res. 21 Nov. 1727 werd hem verleend „sureheance van executie van een geveld vonnis ten sijnen las'e in cas d'appêl van den Raad van Justitie 11 dezer".

Over zijne zaken zie Res. 21 October 1727, 12 April en 27 Mei 1729.

$\mathrm{Hij}$ was Boedelmeester in 1710 en 1711.

Hij overleed vóor 31 Dec. 1734 (zie onder 22).

\section{4 en 15. Tan Eengkong en Tan Tiongqua.}

\section{Res. 28 December 1725 .}

Uijt aanmercking hoe al te meermalen door den Capitain der Chineesen aan den heere Gouverneur Generaal is geklaagt over de weijnige hulpe die den selven van twee sijner lieutenants genaamt Lijonko en Limtsoenko in het afdoen van dagelijkse voorvallende geringe geschillen onder hunne natie mits haare langdurige en nog continueerende indispositie is hebbende, soo is na een voorstel van gemelte sijn Edelheijd verstaan den gedagte Capitain boven de presente 3 lieutenants nog te adsisteeren met 2 andere, mitsgaders daartoe te nemen den gewesen lieutenant tot Cheribon Taneengkong en den boedelmeester Tantionqua, soone van den gestorven capitain Tanboqua, als beijde luijden sijnde van een ordentelijk gedrag.

(Tan Eengkong). Res. 4 Oct. 1729 handelt over een „staande horologie gevonden zijnde in den boedel van zaliger den heere G. G. Mattheus de Haan, 
aan wien dit door Luitenant Tan Engkong te koop gepresenteerd en ter besigtinge was geleverd dog mits het schielijk overlijden van $\mathbf{Z}$. E. niet betaald of weder gerestitueerd".

Bij Res. 3 Juni 1707 werd hij benoemd tot Luitenant der Chinesen op Cheribon tot behulp' van 't Hooft derzelve aldaar Tan Thangko.

Bij Res. 18 Oet. 1729 werd hij ter vervanging van den uit den dienst gedemoveerden Tan Hioko benoemd tot Kapitein der Chineesen tot Cheribon „omme ook met eenen van wegen de Princen aldaar waar te nemen den dienst van Sabandhaar alsoo die bedieningen niet gevoeglijk van den anderen konnen werden gesepareert".

Over de verkiezing van een Capitein der Chineesche natie tot Cheribon instede van den overleden Tan Eenkong, wordt gesproken in Res. 16 Maart 1734.

(Tan Tiongqua). Hij verzocht toestemming der Regeering voor het huren van een stuk wild en woest land dat aan de Compagnie behoorde en naast het zijne lag. Hij gaf voor dit land ten hoogste noodig te hebben tot het planten van suikerriet maar werd verwezen naar het College van Heemraden. (Res. 11 Sept. 1733).

Hij was Boedelmeester in 1717, 1718, 1725, 1726 en 1727.

Hij overleed 19 Dec. 1741 in de gevangenis.

Zijne weduwe was Qua Tjonio. (Zie over hem Bijdr. Kon. Inst. deel 74 (1918) Ni Hoekong).

\section{6 en 17. Nilocko en Ongeengsaij.}

Res. 8 Juli 1729 .

Nademaal de presente 4 luijtenants der Chineese natie alhier volgens getuijgenisse van den Capiteijn Quebauqua door siekte en andere lichaamelijke gebreeken veeltijds buijten staat sijn denselven te kunnen assisteeren in het beslissen en verevenen van geringe geschillen die dikwils of dagelijks onder die van hare natie occureeren en ter decisie van gemelte officieren volgens een aloud gebruijk werden overgelaten, so is op het voordragen van den heere Gouverneur Generael goedgevonden het getal der Chineese luijtenants van nu voortaan te brengen op ses en hetselve uijt dien hoofde met nog 2 persoonen te versterken en daartoe uijt degeene die daarom versoek hebben gedaan aan te stellen den oud Chinees boedelmeester Nilocko en den Chinees Ongeengsaij beijde luijden sijnde van kennis en ervarentheijd.

(Nilocko). Hij was gehuwd met Tan Teengnio, zijne universeele erfgename, en is vermoedelijk 22 Januari 1733 overleden, nalatende vijf zoons van wie twee nog minderjarig. (Vgl. acte notaris Wichelhuijsen van 18 Ang. 1733, No. 4977).

$\mathrm{H}_{\mathrm{ij}}$ was Boedelmeester in 1715 en 1716 , in 1726 en 1727. 
Hij was lid van het College van Boedelmeesteren in 1715 en 1716, en in 1726 en 1727.

Bij Res. 22 Juli 1712 werd hem toegestaan op Lassem een jonk van ongeveer 100 ton te laten timmeren en bij Res. 4 Juli 1725 , het opregten van een arraksbranderij in desselfs tuin bewesten dese stad aan de Ammanusgracht".

Als Luitenant werd hij opgevolgd door zijn oudsten zoon Nihoekong (zie onder 19) den lateren Kapitein (zie onder XI).

\section{Io Seenkong.}

\section{a. Res. 21 October 1729.}

$\mathrm{Na}$ gedane omvrage nodig geoordeeld zijnde te treden tot verkiesing van een ander lieutenant over de Chineesen alhier in de vacante plaats van Tan Enkong die ter resolutie van den $18^{\mathrm{n}}$ deser is gevordert tot Capitein der Chinesen van Cheribon, soo is ten aansien niemand der boedelmeesters alhier sig daartoe heeft aangeboden; op het voordragen van den heere GouverneurGeneraal eenparig goedgevonden en verstaan tot Lieutenant der Chinesen aan te stellen den Chinees I O Seenkong als een persoon sijnde van een ordentelijk gedrag en een goed comportement.

\section{b. Res. 10 Juni 1738.}

Voorts door den Capitain der Chineese natie alhier Niehoekong nevens de luijtenants Tan Tiongqua, Que Oeijko en Oeij Tsomqua bij een seer ampel geschrift werdende vertoont hoe dat zijlieden bij continuatie werden getraverseert in de afdoeninge yan dese en geene saken voor hare wekelijkse vergadering door den mede-luijtenant I O Seenkong die deselve telkens zo zij voorgaven mits zijnen onrustigen inborst sodanig turbeerde dat zij niet sonder veel hooftbreekens tot een finaal besluijt konden geraken en waar en boven denselven nog sig niet ontsag den eerstgem. op een onbetamelijke wijse te attacqueeren met verscheijde brutale en injurierende expressien, waaromme dan door haarl. versogt sijnde dat dese regeering haar tegens gem. I. O. Seengkong geliefden te maintineeren en tot voorkoming van diergelijke verdere gedoenten denselven uijt hare vergadering te dimoveeren en in zijn plaats een ander aan te stellen dan wel hieromtrend sodanige middelen te beramen als tot weering van diergelijke smaatheden en affronten nodig souden wesen; en desenthalven dan in aanmerking genomen weesende, hoe eene 
verbale reproche off bedreijging omtrent gem. I O Seengkong van geen de minste vrugt kan weesen maar binnenkort al weeder aanleijding tot verdere geschillen soude geven ter sake denselven de gemoederen tegens hem verbittert hebbende niet van dat humeur is om die weeder na sig te trecken, zo wierd vervolgens eenpariglijk best geoordeelt denselven ter bewaring der ruste in die Chineese vergadering daar buijten te houden en hem alle acces tot deselve als een medelid te beneemen; weshalven dan besloten wierde denselven van dien dienst te ontslaan met behoud nogtans van zijnen rang en fatsoen als een oud luijtenant van die natie.

\section{Ni Hoekong.}

Res. 6 Februarij 1733.

Nog is op de propositie van den Heer Gouverneur Generaal verstaan in stede van den overleden Lieutenant der Chineese natie $\mathrm{Ni}$ Locqua weder te laten optreden zijnen oudsten zoon den oud-boedelmeester $\mathrm{Ni}$ Hoekong.

Over hem zie onder XI.

\section{Li Hoko.}

Res. 23 Juni 1733.

In stede van den overleden luijtenant over de Chineese natie in name Ongeengsay is op het voorstel van den heere Gouverneur Generaal verstaan te verkiesen en aan te stellen den boedelmeester Lihoko en in plaats van desen laatsten weder tot boedelmeester te eligeeren den Chinees Oeij Tsomko als lieden zijnde die geagt werden daartoe de vereijschte capaciteijt en trouwe te besitten.

$\mathrm{Hij}$ werd tot Boedelmeester benoemd in 1732 en 1733.

\section{Que Oeijko.}

Res. 12 Maart 1734 .

Wijders is verstaan den Chinees Que Oeijko op desselvs versoek en voordragen van den $\mathrm{h}^{\mathrm{r}}$ Gouv. $\mathrm{Gen}^{1}$ aan te stellen 
tot Luijtenant van die natie instede van den overledenen Lim Tsoenko. ${ }^{1}$

\section{Nio Kanko.}

Res. 31 December 1734 .

$\mathrm{Na}$ de afgelopen verpagting der Jaccatrase domijnen de heeren leeden op het voorstel van den heere Gouverneur Generaal zig ter vergaderzaale vervoegt hebbende en aldaar door $Z$ ijn Edelheijt geproduceerde zijnde een request van den Chinees Niokanko dewelke daarbij versoek komt te doen omme tot luijtenant der Chineese natie ter deser stede ter vervullinge van de vacante geraekte plaats door het overlijden van den luijtenant Lim Somqua verkozen te mogen werden, zoo is verstaan daarin te condescendeeren.

Hij werd 31 Dec. 1733 tot Boedelmeester benoemd.

\section{Oeij Tsomko.}

Res. 28 September 1736.

Mits de verkiesinge van Nihoekong tot Capitain over de Chineesen te deser steede vermeld staande bij resolutie van den [ $11^{\text {en }}$ dezer $]$ een plaats onder de luijtenants over die natie zijnde opengevallen en vacant geraakt, so is op de propositie van den heere Gouverneur Generael verstaen uijt degeene die hun persoon en dienst hebben aangeboden, te verkiesen en aan te stellen den oud-boedelmeester Oeij Tsomko.

Over hem, zie bl. $62-64$.

\section{Kou Tsinqua.}

Res. 27 Mei 1738 .

Vervolgens is op den voorstel van den heere Gouverneur Generaal mede nog besloten in steede van den overleeden Chineesen luijtenant $\mathrm{Li}$ Hoeko weder daartoe aan te stellen den

1) Overgenomen uit de Notulen; in margine staat een $\mathbf{R}$. wat beduidt dat het moest worden opgenomen in de Resoluties, wat echter is verzuimd. (Mededeeling van Dr. de Haan). 
alhier remoreerende mede Chinees Kou tsinqua doorgaans genaamt Gou Sinseeng die geoordeelt wierd de daartoe vereijschte bequaamheijd en vroomheijd te besitten.

Hij was in 1738 tevens wijkmeester (Res. 19 Aug. 1738).

Met Kapitein Que Tsoenqua bezat hij arakbranderijen buiten de Diestpoort (Res. 4 Juli 1738).

Maurits van Aarden, Secretaris van Schepenen, was sequester in zijn boedel (a. b.).

\section{5. $\mathrm{Ni}$ Tonqua.}

Res. 13 Juni 1738 .

Insgelijx door den heere Gouverneur Geneneraal al mede nog te kennen gegeven sijnde de noodsakelijkheid ter vervulling der vacante plaats van luijtenant onder de Chineese natie door het jongst verleende ontslag van den luijtenant I. O. Seengkong opengeraakt, en hoe sig onder meer andere van de voornaamste deser volkeren daartoe hadde opgedaan en zijnen dienst aangeboden, den mede Chinees Ni Tonqua, zo wierd al verder goed gevonden denselven daartoe weder aan te stellen.

\section{Oeij Theeko.}

Res. 26 Januari 1740.

In steede van den overleeden luijtenant der Chineesen natie $\mathrm{Ni}$ Tiunko is op den gedanen voorstel van weegen den heere Gouverneur Generaal goedgevonden daartoe weeder aan te stellen den Chinees Oeij Theko.

\section{Oeij Tsomko.}

Over hem, zie bl. $60-64$.

\section{Tan Iko.}

Voor zijne benoeming, zie onder XII. 


\section{a. Res. 14 Januarij 1749.}

Voorts is op het versoek van den Luijtenant der Chinese natie alhier Tan Iko verstaan denzelven van die dienst te ontslaan en hem te permitteeren na zijn geboorteland te retourneeren met een der verwagt werdende jonken mits ingevolge de resolutie deser Tafel in dato 25 Augustus 1747 betalende den tienden penning van sijn capitaal dat derwaarts staat mede te nemen.

\section{b. Res. 2 Mei 1749.}

Op het versoek van den op zijn vertrek naar China staande gewesen Lieutenant der Chineesen Tan Iko is verstaen aan denselven voor de gewone prijzen af te staen 1500 picols peper en 1000 picols thin, mits hij teffens met een avance van $44 \mathrm{p}^{\mathrm{r}} \mathrm{c}^{\text {to }}$ plus minus accepteere 40 stucken ongewilde lakenen en op desen voet ook te stellen den vercoop van peper en thin uijt de hand voor alle andere also het selve apparentelijk den debiet van de voorsz. manufacturen eerder zal te wege brengen dan wanneer men daaromtrent zal komen persisteeren bij het geresolveerde ter sessie van den 22 der gepasseerde maand.

Bij deze occasie ook verstaan te noteeren dat voorn. Tan Iko van de Comp ${ }^{e}$ gekogt en overgenomen heeft $1700 \mathbb{B}$ moernagelen voor 300 rds. 't picol instede dat deselve tot hiertoe naar Japan gesonden en aldaar gedebiteerd werden voor rds 30.-

Res. 23 Mei 1749.

Aan den oud lieutenant der Chineese natie Tan Iko is verstaan conform zijn verzoek bij requeste gedaan te permitteeren zeker stuks land hem in eigendom toebehoorende en gelegen aan de rivier de Crocot met de daarop staande kalkoven die hij op consent deser regeering bij res. van den $26^{\text {en }}$ Juni 1744 aldaar opgerigt heeft, te verkopen met privilegie tot het branden van kalk mits daarvan behoorlijke kenisse gevende aan Heemraden.

Omtrent zijne ovorkomst van Samarang naar Batavia in het laatst van November 1740 zie Bijlage $3, a$ en $b$.

Zie ook over hem Bijdr. Kon. Inst. Dl. 73. So Bing Kovg bl. 372 en deel 74, Ni Hoekong bl. 453 noot 2, zoomede China Review XXI., 138. 


\section{Lim Kocko.}

Res. 7 Mei 1745 .

Op den voorstel van den heere Gouverneur Generael wierd goedgevonden en verstaan den Chinees Limkocko die geweest is Capitain der Chineezen tot Banjermassingh en jongst aan den koning van Johor bestelt heeft het schrijven deser Regeeringh vermelt bij resolutie deser tafel van den $10 \mathrm{Juli} 1744$, voor het volbrengen van zijne commissie aldaer tot een recompens aan te stellen tot derde luijtenant over de Chineese natie alhier dog buijten consequentie om dat getal eens voor al te houden op twee stux.

$\mathrm{Hij} \mathrm{kreeg} \mathrm{de} \mathrm{opdracht} \mathrm{om} \mathrm{met} \mathrm{vier} \mathrm{dienaren} \mathrm{van} \mathrm{de} \mathrm{andere} \mathrm{Chineesche}$ officieren mede te varen ter bekruising van de noord, om bij ontmoeting van de uit China komende jonken asn de nachoda's nader en duidelijk te doen verstaan de intentie der Regeering. (Res. 16 Dec..1746).

\section{Tsou Tsoen Seeng.}

Voor de benoeming van Tsou Tsoen Seeng (ten rechte So Soen Sing) zie onder XIII.

\section{Testament ${ }^{1}$.}

$$
\text { No. } 3477 \text {. }
$$

Op huijden den 13 April 1751 compareerde voor mij Jacob Levier, Notaris publycq, bij d'Edele hoge Regering van Nederlands India g'admitteerd binnen de stad Batavia residerende, present de naar te melden getuijgen, de Lieutenant der Chineese Natie alhier Souw Tsoen Seeng, mij bekend; wezende ziek van lichaame, nogthans in het volle bezit der gerequireerde bequaamheden om te kunnen en mogen Testeeren, waar toe hij betuijgde uijt zijn eijgen motif en vrije wille als nu genegen te wezen, revoceerende ten dien eijnde alvorens alle Testamenten en Codicillen bij hem voor dato dezes enigzints gepasseert,

En dan de novo disponeerende verklaarde de Testateur aanvankelijk zijne expresse begeerte te wezen, dat na zijn dood, uijt slavernij in vrijheijd gesteld zullen werden zijne naar volgende Lijffeijgenen, als:

\footnotetext{
1 Landsarchief.
} 
de slaaf Sumbat van boegies en slavinnen Pekele van Sumbauwa, Baboe van Baly, terstond na zijn overlijden.

de slavinnen Haliau van Nias, Simoly van Balij en Pegiok van Batavia; dewelke niet eerder dan drie jaaren na zijn Testateurs overlijden zullen moeten werden g' Emancipeerd, geduurende welke tijd zij bij d'ondertenoemen Executeurs zullen dienstbaar blijven.

de slaven Tangok, Doempoe, Amal en Noena, alle van boegies, thans arbeijdende op zijn Testateurs gehuurde zuijker molen, alwaar dezelve almede bevorens vrij te werden, zullen moeten blijven dienen tot d' expiratie van de huurtijd van even genoemde molen. Zulcx alles nadat hij Testateur, nopens den inhoude van het daartoe leggende placcaat was onderregt.

Wijders verklaarde de Testateur te Legateeren aan den E Heere Godlieb Johan Adolph van Trabe, drossaard dezer stads ommelanden, Eene somma van twee Duijsend Rijxdaalders, dog zal de heer Legataris d'ondertenoemen Executeurs tot voldoening van dat Legaat niet eerder kunne aanspreeken dan na verloop van drie jaaren na zijn Testateurs overlijde ende heeft de Testateur in alle de verdere goederen bij hem met zijn overlijden t' ontruijmen en agter te laten tot zijn algehele en universele Erfgenaamen genomineert en g'institueerd, gelijk hij daarinne nomineert en institueert bij dezen, zijne vijff zoonen, Souw Goatko, meerderjarig, Souw Houwko oud agtien, Souw Haijko, oud seventhien, Souw Hiauwko, oud seven jaaren, alle in Loco, en Souw Peeko oud een en twintig jaaren, woonagtig tot Aijmuij in China, zijn moeder, Tsoe I-Engnio, zijn broeder Souw Koko, beijden tot Aijmuij voorschr: woonagtig, zijn alhier remoreerende broeder Souw Ki-Etko, en wijff Oeij Goeijnio, nevens Souw Tsonglien, oud Twee en twintig jaaren, en Souw Tiseeng, oud ses jaaren, zijnde beijden zoonen van zijn evengenoemde broeder Souw Ki Etko en dat zoo wel in de roerende als onroerende goederen, item actien en crediten, namentlijk zijn zoon Souw Goatko en neeff Souw Tiseeng te saemen in een tiende deel, en de overige ider hooft voor hoofd in een gelijk tiende deel; zullende de portie off portien der voor overlijdende de in leven zijnde moeten accresseeren. Tot Executeur en Executrice van dezen Testamente mitsgaders voogd en voogdesse over de minderjarige bij hem na te laten mede erfgenaamen en hunne te erven Penningen en 
middelen steld de Testateur zijn voornoemde broeder Souw Kietko en wijff Oeij Goeijnio, mitsgaders nog dezelve Souw Kietko alleen tot voogd over zijne twee voornoemde kinderen Souw Tsonglien en Souw Ti Seeng, alles met de daar toe staande magt en speciaal die van assumptie en subrogatie secludeerende de Testateur met Eerbied uijt zijn nalatenschap d'Eerw. heeren Boedelmeesteren dezer stede, on-aangezien de preadvertentie dien aangaande gedaan.

Dit bovenstaande aan den Testateur duijdelijk zijnde voorgehouden, verklaarde hij te wezen zijn Testament, begeerende dat het als zodanig mogte valideren, dan wel als codicill off zodanig als best zal kunnen bestaan niet tegenstaande alle gerequireerde plegtigheden daarinne niet behoorlijk waaren g'observeert.

Aldus getesteert even buijten de Nieuwpoorte dezer stad, alwaar de compt was ziek leggende, present Jeroboam Jacobs en Elias Dias clercquen als Getuijgen -

$$
\text { gest. }^{\text {d }}
$$

$\mathrm{m}$

J. Jacobsz.

bij Souw Tsoen Seeng. J. ${ }^{\text {b }}$ Levier

E. Diasz.

Nots.

Aan het hoofd van bovenstaande acte staat:

den 13: Maart 17532 copia verleend aan hierinne genoemde Oeij Goeijnio

den 13 April 1754 Een »

Goeijnio.

Hij was Boedelmeester in 1744-1745, en 1745-1746 en in 1746-1747.

Bij Res. 21 Maart 1747 werd besloten den Boedelmeester Souw Tsoenseng "over het ligtvaardig indienen van een klachtschrift ten exempel van andere onbillijke suppleanten te condemneren in eene boete van vijftig rds ten behoeve van het Seminarie alhier."

Als pachter van de inkomende en uitgaande rijst werd hem bij Res. 30 Oct. 1750 surcheance van betaling verleend.

Hij overleed tusschen 13 April 1751 toen hij zijn testament maakte en 4 Mei 1751. Bij resolutie van laatstgenoemden datum wordt gezegd dat zijn broeder Souw Ki Etko mede-executeur in zijn boedel is.

\section{Tang Wang Seeng en 32 Oeij Tsilauw.}

Res. 10 December 1748 .

In stede van den overleden Limkocko is verstaan tot luijtenant Dl. 78. 
der Chineesen natie aen te stellen den Chinees Tang Wangseeng en nadien het getal van de Chineese inwoonders naeder van jaar tot jaar accresseert en het getal van drie lieutenants overzulx niet toerijkent schijnt, dienstig geoordeelt het getal van de sodanige met een vierde te vermeerderen en daertoe te verkiesen haren Secretaris Oeij Tsielauw, so om behoorlijk agt op die natie te slaan als ten dien eijnde aldus bij maandelijkse tourbeurten twee derselve precise sullen kunnen vaceeren en bij alle voorvallende zaken gerequireert worden, welk oogmerk vermids die menschen veeltijds haar eijgen bezigheden en handelszaken hebben, door een minder getal so wel niet kan bereijkt werden.

Tan Wangseeng had twee arakbranderijen in huur welker product hij „wegens de tegenwoordige slegte conjecture des tijds niet genoeg kan debiteeren". (Res. 17 Juli 1750).

Hij verzocht (Res. 7 Juli 1752) ontslag van zijn officie, vermits hij zig gereduceert zag tot sodanigen staat dat het hem geheel en al onmogelijk is te supporteeren de meerdere depenses welke hij uit hoofde van hetzelve genootsaect was te doen". Er werd echter besloten daarop niet te disponeren. (Vgl. Res. 18 Juli en 3 Aug. 1752).

Hem werd vergund (Res. 13 Dec. 1757) een steenen huis, gelegen buiten de Diestpoort, in het Westerveld, het zesde deel van blok $O$, in te richten ,tot eene verzamelplaats der namen mitsgaders de offerassche van overleden Chineezen den naam Tan voerende". Hij overleed insolvent. (Res. 15 April en 15 Juli 1760.)

Over Oeij Tsilauw, zie onder XIX.

\section{Lim Tjipko.}

a. Res. 3 Juni 1749.

Voorts is in stede van den ter sessie van den 14 Januarij deses jaars van den dienst van Lieutenant der Chineese natie ontslagen Tan Iko goedgevonden en verstaen daartoe aan te stellen den Chinees Lim Tjipko.

Zie over hem onder XV.

\section{Ong Eng Saaij.}

Res. 29 December 1750 .

Tot Lieut. der Chineesen in plaats van den op den 7 Julij dezes jaars tot Capit. dier natie opgetreeden Oeij Tsielauw is 
verstaan aan te stellen het lid in het Collegie van boedelmeesteren der onchristen sterfhuijzen Ong Eng Saaij mitsgads. in zijne steede tot boedelmeester den Chineesen inwoonder Lim Ko-Enlo en tot Secret. der vergadering van den Capit. en Lieutenants-item translateur in hare taale in plaats van voorsz. Oeij Tsjielauw den Chinees Oeij Liang Son met het tractement en honneur daartoe bij resolutie van den 26 Meij A 1747 gesteld, mids hij zo wel als voorsz. boedelmeester voor Scheepenen behoorlijk b'edigt werde.

Hij was huurder van een stuk Compagnie's land genaamd Pondok Jagon (Res. 21 Nov. 1755).

Zijne weduwe was Louw Sinnio. (Res. 30 Juli 1756).

\section{Lim Ki-Enko.}

\section{a. Res. $15 \mathrm{Junij} 1751$.}

Insteede van den overleeden Tsouw Soen Sing is verstaan tot Lieutenant van de Chineese natie te laten optreden Lim Ki Enko mitsg: in sijne plaatse tot Lid in 't Collegie van Boedelmeesteren der onchristen sterfhuijsen aan te stellen den Chinees koopman Que Hoko en tot Secretaris der Chineese officieren den tolk in die tale en meede Chinees Oeij Tjamko, in steede van den overleeden Oeij Liang Son, mits de twee laaste voor Scheepenen presteeren den eed daartoe staande.

Bij Res. 9 April 1754 werd hem uitstel verleend voor de voldoening van hetgeen hij nog schuldig was wegens een aan hem bij Res. 26 Oct. 1751 verleend voorschot van rds. 10000. (Vgl. ook Res. 26 Oct. 1753).

In Res. 15 Maart 1763 wordt hij genoemd als huurder van tiree suikermolens op het land Concordia.

Den Waterfiscaal werd opgedragen zijne schuld aan de Compagnie in te vorderen desnoods door middel van contrainte. (Res. 23 Maart 1763). Hij overleed insolvent (Res. 5 Nov. 1765); wegens van de Compagnie gekochte tin had hij een achterstal groot $f$ 840.-

\section{6, Lim Theecko.}

a. Res. 8 November 1754 .

In stede van den te deser dage overledenen Lieutenant der Chineese natie Ong Eeng Saij is verstaan daartoe uijt de versoekers weder te nomineren en aan te stellen den Chinees 
inwoonder alhier Lim Theecko die den gewoonen eed van purge sal moeten afleggen aan handen van Scheepenen deser stede.

Bij Res. 3 Dec. 1754 werd zijne huur van het land Pondok Jagon gecontinueerd voor zes jaren, mits betalende 50 rds. in 't jaar.

De met een dubieusen boedel overleden Luitenant Lim Theko was aan de Compagnie schuldig rds. 5700 voor tin, hem bij Res. 31 Mei 1763 verkocht, om de helft met contanten en de helft met suiker te worden betaald (Res. 30 Dec. 1763).

In zijn door schulden genoegzaam insolventen boedel waren executeurs Lim Djoenko en Lim Keeko. (Res. 6 Deo. 1764).

\section{Khouw Hong Liang.}

Voor zijne benoeming, zie XV (bl. 68).

${ }_{n} \mathrm{~K}$ 'hoé hong-lëang was a native of Cheang-chew and became Captain China of Batavia; he was also of a liberal disposition, and truly generous..." (The Chinaman abroad: or a desultory account of the Malayan Archipelago, particularly of Java, by Ong Tae-Hae, Shanghai, 1849, in Chinese Miscellany). Vgl. Wylie, Notes on Chinese Literature bl. 53.

De Engelsche vertaling is van den zendeling W. H. Medhurst; eene Hollandsche vertaling hiervan komt voor in Tijdschrift van Ned.-Indië, 14 ${ }^{\circ}$ Jaarg. (1852), $2^{\bullet}$ deel, blz. 1. Eene bewerking van deze Hollandsche vertaling is in 1858 te 's-Gravenhage uitgegeven onder den titel: „Chineesche aanteekeningen omtrent Nederlandsch Indië. (Naar de Engelsche vertaling door Dr. W. H. Medhurst, vertaald door R. Browne)".

Als pachter van de topbanen in 1748 werd hem bij Res. 21 Febr. 1749 atterminatie voor twee jaren verleend.

Hij was eigenaar van twee suikermolens op Karang Tjonggok. (Rea. 6 April 1753).

Bij Res. 16 Aug. 1754 werd hij (met elf anderen) aangesteld tot wijkmeester in de ,Chineese Campong”.

Hij was mede-executeur in den boedel van Luitenant So Tsoenseeng. (Res. 21 Nov. 1755).

Den $18^{\text {en }}$ Sept. 1772 makte hij zijn testament (Notaris Mr. Pieters Lammers) waarbij tot executeuren van "den met zeer veel schulden bezwaarden boedel" werden aangesteld Bok Kinhi en Hiapko. (Res. 10 Dec. 1772).

Hij overleed vóór 2 Oct. 1772. (Zie Res. van dien datum).

\section{Thee Poanko.}

Res. 18 December 1759.

Door het overlijden van den Chinees Tan Wang Seeng een plaats van Lieutenant onder gedagte natie vacant geraakt zijnde, 
is verstaan tot desselfs vervulling uit degeene die daarom versoek hebben gedaan, weder aan te stellen den Chinees Thee Poanko.

"het debet van den geaufugeerden luijtenant der Chinesen The Poanko" wegens de hem volgens besluit van 1763 verkochte 200 picols tin, bedroeg f 3852.12 . (Res. 15 Nov. 1765).

In Res. 5 Febr. 1768 heet hij „den gevlugten en in de boeijen overleden gewezen Luijtenant der Chineese natie alhier".

\section{Khouw Tjangko en 40 Louw Nungko.}

\section{Res. 10 Juni 1762 .}

Te meermalen aan deze tafel over het successive zedert eenige jaaren toegenomen getal van Chinese ingezetene alhier discours gevallen en thans door zijn Edelheijd aan de Heeren Leden te kennen gegeven zijnde dat daar omtrend zedert eenigen tijd nauwkeurige informatie hadde laten nemen en volgens zekere rapporten ontwaar was geworden dat het getal derzelve al zeer aanmerkelijk was en volgens dezelve dat van 't jaar 1740 zelfs zoude surpasseren, onder een verder voorstel of het niet convenabel was gelijk men nu en dan al eens van opinie was geweest om even als vóór het jaar 1740 wanneer alhier over de Chineesen als officieren gesteld waren een capitein en zes luijtenants, namelijk: Nie Hoekong capitain, en Tan Tiongko, Que Oeijko, Oeij Tsomko, Khouw Tsinko, Niey Tjonko en Oeij Theeko luijtenants, het presente getal der officieren van de Chineesche natie meede te vermeerderen ten eijnde in 't generaal beter zorg en reguard op die van hunne natie te konnen slaan te meer de tegenwoordige Capitain en vier luijtenants daarom aanzoek bij zijn Edelheijd gedaan hadden, zoo is, ingevolge de propositie van zijn Edelheid goedgevonden en verstaan evenals vóór het jaar 1740 het getal der Chineese officieren mits de toenemende menigte van die inwoonderen voor het vervolg weder dusdanig op een Capitain en ses luijtenants te bepalen en dienvolgende tot suppletie van de twee luijtenantsplaatsen, dewelke aan de ses thans ontbreken nog tot luijtenants aan te stellen de Chineesen Khouw Tjangko en Louw Nungko.»

(39) $\mathrm{Hij}$ was eigenaar van twee tezamen getrokken stukken land, gelegen omtrent 7 à 8 uren gaans oostwaarts buiten de stad in 't Oosterveld, het vierde deel van blok 10, waar hij zeven suikermolens had. 
Hij overleed, vóór 22 Juni 1770. In zijn testament van 12 Juni 1770 is sprake van zijne twee zoons. Executeuren in zijnen boedel waren zijne weduwe Lim Tjonio, zijn zoon Khouw Hoe-tieeuw, Bok Kim Liam en I-onko Anko (Res. 29 Juli 1774).

Zijn zoon Khouw Goan Kong kreeg op 21-jarigen leeftijd veniam aetatis. (Res. 2 Juni 1772).

(40) In Res. 11 Jan. 1743 wordt gesproken van het frivool voorgeven van den Chinees Lauw Nungko als leverancier van kromhouten, kort vóór den opstand.

\section{Gouw Boenko.}

Res. 30 December 1763 .

Ook is mits het overlijden van Lim Theko verstaan tot Luitenant der Chineesche natie aan te stellen den Chineeschen Boedelmeester Gouw Boenko en de hierdoor vacante Boedelmeestersplaats te begeeven aan den Chinees Louw Sinkong.

Bij Res. 6 Aug. 1765 krijgt zijne weduwe en boedelhoudster Lim Seeuwnio brieven van atterminatie voor den tijd van drie jaren.

\section{Tung Ingko.}

Res. 6 April 1764.

In stede van den overleden Lim Ki-Enlo is goedgevonden en verstaan bij dezen tot Luitenant van de Chineesen aan te stellen den Chinees Tung Ingko.

Hem wordt bij Res. 27 Dec. 1768 in admodiatie afgestaan de pacht van den te heffen tol van de wajangspelen over 1769. Ook kon hij krijgen de admodiatie der topbanen en was daarom zeer geschikt om 't een met het ander in behoorlijke orde zonder onderlinge moeilijkheden in pagt te hebben. Ook bood hij een hoogere som.

\section{Louw Sinkong.}

Res. 5 Juli 1764.

Insteede van den geaufugeerden The Poanko is goedgevonden en verstaan bij deezen aan te stellen tot Luitenant van de 
Chineesen den Boedelmeester Louw Sinkong en in des laatsten plaats tot Boedelmeester den Chinees Gouw Sienko.

\section{Oei Hingko.}

\section{Res. 19 Februari 1765.}

In steede van den overledenen Gouw Boenko is goedgevonden en verstaan Oei Hinko bij desen te benoemen en aan te stellen tot een der luitenants van de Chineesen alhier.

In Res. 20 Maart 1772 heet „de Luitenant der Chineeschen Oeij Hingko een der gegoedsten van die natie".

Over hem zie onder XVII.

\section{The Lionko.}

Res. 6 Mei 1769.

In plaats van den overleden Luitenant der Chineesen Lauw Limko is op de propositie van den Heere Gouverneur Generaal goedgevonden en verstaan daartoe te benoemen den Chinees The Lionko.

\section{Tan Tjaijko.}

Res. 3 October 1769.

Tot Luitenant der Chineesen alhier in plaats van den aflijvigen Louw Sing Kong is verstaan aan te stellen Tan Tjaijko en in dies steede weeder tot Boedelmeester den Chinees Oeij Koenko.

In Res. Dec. 1772 wordt zijne weduwe Khouw Tjinio genoemd en is sprake van "de sobere nalatenschap".

\section{Lim Teko.}

Res. 22 Juni 1770 .

Ook is verstaan in steede van den overledenen Kouw Tjanko tot Luitenant der Chineesen alhier aan te stellen Lim Teko. 
Hij kreeg vergunning (Res. 11 Dec. 1761) twee zijner suikermolens op het land Tjikokol in het Tangerangsche te verplaatsen naar zijn land Pondok Seloet, gelegen boven de post Anké, waar ook een steenbakkerij was. (Res. 12 Maart 1762).

In zijn "door schulden nagenoeg insolventen boedel" waren Lim Djoenko en Lim Kieko executeuren. (Res. 6 Dec. 1764).

\section{Gouw Poansoeij.}

Res. 2 October 1772 .

Tot Luitenant der Chineeschen alhier is goedgevonden en verstaan aan te stellen den Chinees Gouw Poansoeij, in plaatse van den overledenen Kouw Hongliang.

\section{Ong Tjako.}

Res. 17 November 1772 .

Tot Luitenant van de Chineeschen alhier in plaatse van den overledenen Tan Tjaijko is goedgevonden en verstaan aan te stellen den Chinees Ong Tjako.

Van zijn boedel is sprake in Res. 23 Juni 1775 . Hij liet drie zoons en eene dochter na. Tot executeurs had hij aangesteld Tjoa Goatse, Ong Bouseeng en den oud-Capitain van Ternate Ong Hiamko.

\section{The Tjako,}

Res. 15 December 1772 .

Nog is goedgevonden en verstaan tot Luitenant der Chineesche natie alhier aan te stellen den Chineesch en oud-Boedelmeester van Samarang The Tjako, in plaatse van den overledenen Ong Tjako.

\section{Swa Thoenko.}

\section{Res. 31 Januari 1775.}

Tot Luitenant der Chineesen in plaatse van den voorgenoemden Ting Ingko is goedgevonden en verstaan aan te stellen den Chinees Swa Thoenko.

Over hem zie XVIII. 


\section{Ong Soeseeng.}

Res. 4 Augustus 1775.

Tot Luitenant der Chinesche natie alhier in plaatse van den overledenen Lim Theeko aan te stellen den Chinees Ong Soeseeng.

Hij was een zoon van den vroegeren Luitenant Ong Eng Saaij (34).

\section{Tung Pi-Enko.}

Res. 19 December 1775.

Voorts in zijne plaatze ${ }^{1}$ tot Lieutenant aan te stellen den Chinees en Boedelmeester Tung Pi-Enko.

\section{Ko Kimko.}

Res. 29 December 1775.

Tot Lieutenant der Chineeschen in plaatse van den overledenen The Tjako is goed gevonden en verstaan aan te stellen den oud Chineesch Boedelmeester Ko Kimko.

Hij maakte 27 Juni 1787 zijn testament. Zijn weduwe was Tan Sinnio. (Res. 29 Jan. 1788). Executeuren waren Ong Tjoeseeng, Ko Tamko en Liouw Ikong. (Res. 22 Maart 1791).

Over de geschillen tusschen de weduwe en deze exeouteuren, zie Res. 8 Maart, 22 Maart en 21 Juni 1791.

\section{Njo Koangko.}

Res. 8 Juli 1777.

Tot Luitenant der Chineesche natie alhier, in plaatze van den overledenen The Liongko, is goedgevonden en verstaan aan te stellen den Chinees Njo Koangko.

\section{Tan Hoelo.}

Res. 2 December 1783.

Mits het overleiden van den Luitenant der Chineese natie

${ }^{1}$ N.l. van den tot Kapitein bevorderden Luitenant Oeij Hingko. 
Gauw Pang Sooij is goedgevonden en verstaan weeder daartoe aantestellen den Chinees Boedelmeester Tan Hoelo, en in plaats van deezen laatsten tot Boedelmeester den meede Chinees Tan Pi Seeng.

Hij was Boedelmeester van 22 Dec. 1775 tot 2 Dec. 1783.

Zijn plan tot tegengang van zeeroof werd bij Res. 28 Juni 1785 geapprobeerd.

Zijne weduwe Oeij Tjoanio en Tan Tjeeuwsing waren executeuren in zijnen boedel. (Res. 1 Juli 1791).

Als zijne zoons worden genoemd Tan Limseeng en Tan Tjoeseeng. (Res. 2 Aug. en 19 Dec. 1791).

\section{Oeij Biankong.}

Voor zijne benoeming, zie XVIII.

\section{Lim Hantan.}

Res. 12 October 1787 .

Inplaats van den overleden Luitenant der Chineezen natie alhier Ko Kienko is nog goedgevonden en verstaan als zodanig weder aan te stellen den Chinees en geweezen Boedelmeester der Chineezen en andere onchristen sterfhuisen Lim Hantan.

Hij was Boedelmeester van 15 Jan. 1773, in 1774 en 1775.

\section{Oeij Geeko.}

Res. 22 December 1789.

Nogh is goedgevonden en verstaan op den voorstel van den heer Gouverneur Generaal tot Luitenant der Chineesche natie alhier aan te stellen, in steede van den overleeden Tan Hoelo, den Chinees en praesenten Pachter van de in en uitgaande rechten Oeij Geeko.

Hij overleed vóór 28 Sept. 1790. Zijne executeuren waren Oeij Hongko en de 17-jarige Oeij Tjoeijseng (vermoedelijk zijn zoon). 


\section{Tan Poko.}

Voor zijne benoeming, zie XIX.

\section{Lim Tjoengkong.}

Res. 26 October 1790.

Ook is op den voorstel van welg. Heer Gouverneur Generaal goedgevonden en verstaan .... aan te stellen .... tot Luitenant der Chineesche natie alhier, in plaats van den overleeden Oeij Geeko, den Secretaris dier natie Lim Tjoengkong.

Hij werd bij Res. 25 Aug. 1769 benoemd tot Secretaris der Chineese natie in plaats van den overleden Oeiw Jouiwko.

\section{Gouw Tjangsie.}

Res. 8 Februari 1791.

Insteede van den overleeden Luitenant der Chineesehe natie alhier Lim Hantam, is op den verderen voorstel van welm: Zijn Edelheid goedgevonden en verstaan, weder als zoodanig te benoemen den Chinees Gouw Tjangsie.

Hij was mede-executeur in den boedel van Kapitein Ong Tjoeseeng (XIX). Zie Res. 14 Februari 1792.

\section{Tan Kwanko.}

Voor zijne benoeming, zie XX.

Hij was Boedelmeester in 1790 en 1791.

\section{Lim Tiangseeng.}

Res. 16 Maart 1792 .

In plaats van den overledenen Lieutenant der Chineesche natie Tan Quanko, is goedgevonden en verstaan als zodanig weeder aan te stellen de Boedelmeester Lim Tiangseeng en 
voorts in steede van hem tot Lid in het Collegie van Boedelmeesteren der Chineezen te benoemen den Chinees Oeij Tanko.

Hij werd benoemd tot Boedelmeester bij Res. 24 Dec. 1790 en Res. 21 Juni 1791.

\section{Tan Peengko.}

Res. 13 November 1792.

Mits het overleiden van den Luijtenant der Chineesche natie alhier Tan Poko - is goedgevonden en verstaan weder aan te stellen den Boedelmeester Tan Peengko, en in steede van den laatstgemelde tot Boedelmeester te benoemen den Chinees The Honko.

Hij was Boedelmeester in 1791 en 1792.

\section{6. ${ }^{1}$ Oeij Tamko.}

Res. 9 Jan. 1795.

Hij moet in hetzelfde jaar zijn vervangen door Tee Honko maar op welken datum is niet gebleken.

Hij was Boedelmeester in 1793 en 1794.

\section{Tee Honko:}

Res. . . . 1795 .

Hij was Boedelmeester in 1792, 1793 en 1794.

\section{Gouw Kocko.}

Res. 20 April 1798.

Hij wordt genoemd in Ned. Ind. Plakaatboek XIV, bl. 222 (11 Oct. 1805).

1 De tekst van de resoluties waarbij de onder $66-73$ vermelde Luitenants zijn benoemd is te vinden in het Landsarchief. 


\section{Tan Soeijko.}

Res. 27 Dec. 1800.

Hij was Boedelmeester in 1785-1790 maar bij Res. 24 Dec. 1790 werd verstaan hem en zijn collega Tan Piseng „uithoofde van de tegens hen ingekomen klagten wegens hun slecht en aanstootelijk gedrag te ontslaan".

\section{Kang Phoboen.}

Res. 6 Jan. 1801.

\section{Souw Kongko.}

Res. 26 Oct. 1809.

Hij was Boedelmeester van 9 Jan. 1795 tot ten minste 1800.

\section{Lie Tongong.}

Res. 30 Nov. 1809.

Bij Res. 26 April 1809 werd de Chineesche suikermolenaar te Cadaw en Selapatjan Lie Tongong begunstigd met den titel van oud-luitenant der Chineesen. (Ned. Ind. Plakaatboek XV, bl. 678).

\section{Tan Mappan.}

Res. 30 Nov. 1809. 


\section{Bijlage 1.}

a. Generale Resolutiën des Casteels Batavia, genomen bij den Gouverneur Generaal en de Raden van India sedert pro. October tot ultimo December anno 1754 .

Donderdag 7 November 1754.

Vervolgens met relatie tot dese materie de novo herlesen sijnde, seker voor eenige tijd ingedient en ter resumptie onder de gesamentlijke heeren leden rond geweest, mitsgaders thans weder ingebragt request van den capitain en verdere officieren der Chineese Natie behelsende in substantie hoe dat hunne landgenoten alhier ter plaatse, in steede van te erkennen de grote voorregten, privilegien en vrijheeden, haarlieden meer dan aan eenige andere der Oosterse Natien geaccordeert, en daar van als goede en vredelievende onderdanen met dankbaarheijt te profiteeren, veele van deselve dagelijks meer en meer quamen uijttespatten in allerleije ondeugden en bedriegerijen, waarover hun supplianten dagelijks klagten wierden aangebragt, die sijlieden egter als ontbloot van eenige magt, tot groote prejuditie van veele onnosele lieden, niet in staat waren te beslissen.

Dat er onder andere veele Chineese waren, welke sonder beroep of professie sijnde, hun werk maakten die van hunne eigene natie die of jongst aangekomen of uijt sig selfs onnosel sijn, door aller leije listen en streeken van 't hare te ontvreemden etc.

Dat dese quaatwillige, sig funderende eensdeels op hare ervarentheijt om sig 't sij door getuijgen van haar soort, of andere dier gelijke middelen, te redden, en anderen deels op de onervarentheijt en 't onvermogen van de onnosele voorwerpen van haar bedrog wel verre van sig te kreunen of te ontrusten over de klagten die dese laasten aan de supplianten komen te doen, haar selfs niet eens verwaardigen bij hun te komen, wanneer sij door den Chinesen bode werden gedagvaard, als wel overtuijgd sijnde van het onvermogen der supplianten om haarlieden tot eenige de minste vergoeding of restitutie te constringeren. 
Dat oversulx dese arme luijden bij hun supplianten geene satisfactie kunnende obtineren en soo min de wegen van regten kundig als van genoegsame middelen tot het enthameeren van eenige proces voorsien sijnde, genoodsaakt wierden hunne wettige pretentie te laten varen en de autheuren van haar ongeluk straffeloos van alle verdere aanspraak te libereeren, die op dusdanigen wijse in haare quade menees gestijft wierden.

Dat sulks thans bereets soo verre de overhand hadde genomen, dat sij supplianten uijt bedugting der quade gevolgen die hetselve onvermeijdelijk na sig moeste sleepen, en ingevolge van haar pligt, te rade waren geworden dese Regering van alle 't selve en nog veele andere in swang gaande sinistre en quade practijquen kennisse te geven, onder eerbiedigen voorslag der middelen welke onder derselver correctie theijlsaamst tot weering van dit bereets wortelvattende quaad soude kunnen werden geappliceert en bepaald werden in de volgende drie hoofdpoincten te weten:

Eerstelijk, dat sijlieden door dese Regeering gemagtigt wierden om allerleije questien en geschillen ter waarde van Rds.vijftig en daar onder te beslissen.

Ten tweeden, dat tot indruk van vreese en ontsag haar een blok mogte werden toegestaan om quaaddoenders en onwillige daarin op te sluijten, en

Ten dèrden, dat haar ten dien eijnde dienaren mogen werden vergunt om sodanige quaadwillige op te vatten en desnoods met geweld voor haar te brengen, waarvan de supplianten sustineerden dat seer veel goede vrugten en gevolgen te wagten soude wesen etc. en

Ten vierden of laastelijk, dat ook nog van veel nut scheen te sullen sijn, dat alle diegeene, welke onder hunne natie, door de supplianten bij naspeuring en ondersoek, bevonden souden werden onnutte leeglopers en quaatdoenders te sijn, jaarlijks bij namen aan dese Regering wierden opgegeven, om na China versonden te werden, met interdictie van oijt wederom in dese colonie te komen, op poene van vijf en twintig Rijksds. door de Nachodas der respective jonken te verbeuren, voor ieder sodanige versondene, welke sijlieden terug souden brengen. 
Zo wierd over dit alles int breede gedelibereert en onder anderen in aanmerking genomen wesende, dat alhoewel de menigvuldige quade practijcquen en ongebondentheeden die onder de Chineese natie in swang gaan, wel komt te vereijschen dat daa! tegen voorsien werd, door eenig meerder pouvoir aan de gem officieren te verleenen ten eijnde verscheijde ongebondene en slegte subjecten onder die natie wat beter in bedwang te kunnen: houden, het egter om verscheijdene politicque redenen nie raadsaam sij haar sodanig een magt en vermogen te verlenen, dat alleen aan de justitieele collegien in 't criminele eijgen is, voornamentlijk het toestaan van een blok en sodanige dienaren, welke sij komen te versoeken, nadien het niet buijten apparentie sij dat daarvan nu en dan een quaad gebruijk soude maken. al waaromme goedgevonden en verstaan wierd het tweede en derde lid van hunnen voorstel finaal van de hand te wijsen. en daar en tegen met betrecking tot het eerste en laaste haa: te accorderen het volgende.

Eerstelijk, dat gelijk in vroegere dagen den Capitain der Chineese natie conform sekere periode te vinden in de al van voor lange tijden successive door dese Regering verleende commissie aan deselve bij de aanvaarding van hunne voorsz. qualiteit de faculteijt is gegeven, om, met communicatie sijner lieutenant; alle kleene voorvallende saken onder hare natie alhier uijt name deser Regering (gelijk daarbij vermeld staat) af te doen en te beslegten mits de grote of dubieuse renvoijerende daar het behoord, sij cook alsnu van dat voorregt sullen mogen blijven jouiseren, met permissie daar en boven om domestique differenten tot Rds. 25 toe dog niet daar boven in hunne wekelijkse vergaderingen af te doen na den teneur van hunne wetten en gewoontens, behoudens dat de succumbanten het regt van beroep voor Commissarissen van klene gerigtsaken deser stede sal werden overgelaten.

Ten tweede, dat in stede van hun een eijgen blok te accorderen als veel te sorgelijk sijnde, den bailluw en landdrost ais er goede redenen voor zijn, dewelke ter hunner kennisse sullen moeten gebragt werden, verpligt sullen wesen desulke die aa hun door de officieren der Chinese natie werden overgeleverd, in hare blocken te sluijten en te houden, dog niet langer dan den gewonen tijd van driemaal vier en twintig uuren wanneer 
den geapprehendeerden, soo den eijscher sulx begeerd, ten sijnen kosten door den officier in gijseling sal werden gesonden teneijnde de saak bij den dagelijksen regter na behooren sal kunnen werden getermineert en afgedaan.

Ten derden, dat soowel den bailluw als landdrost sooals dat tot nog toe in eenige opsigte plaats is hebbende, op het versoek der voorsz. officieren en bij grote noodsake deselve met hunne substituten en verdere dienaren van de justitie sullen hebben te assisteren teneijnde degene die na de gedane aansegging of dagvaarding sig onwillig betoonen om voor gedagte officieren van de Chineese natie te compareeren op te halen of op te vatten, mits geassisteert wesende door den Chinesen bode.

Ten vierden of laastelijk de gem. Chinese officieren, ingevolge hunnen voorstel te demanderen en te gelasten om alle jaren tegens het vertrek der Chineese jonken aan dese Regeering ter dispositie op te geven de namen en het getal der ondeugende subjecten, die onder hunne natie gevonden werden en die sij sustineren dat onnutte instrumenten in deze colonie sijn, om, of naar China teruggesonden dan wel na goedvinden anders daarover gedisponeert te werden, en wijders de respective annachodas der jonken te interdiceren sulke versondene persoonen elders anders dan in China uijt te setten, of te laten hunnes weegs gaan, dan wel weder terug te voeren op een boete van Rds. 25 voor ieder sodanige ten behoeve van den ontdecker of aanbrenger.

Batavia in $\mathrm{t}$ Casteel dato voorsz.

was geteekend: Jb. Mossel, J. v. d. Waeijen, Ps. As. van der Parra, L. Hooreman, Pr. van der Velde, J. A. van Hohendorff, D. van Rheeden, Adriaan de Nijs, H. van Basel, J. van Riemsdijk en Michiel Romp secretaris.

\section{Bijlage 2.}

a. Res. 26 Nov. 1666 .

Verscheijde malen in 't brede gesproken sijnde van 't capiteijnschap der Chinesen alhier nu al veele maenden sijnde vacant geweest ende aengemerckt zijnde dat niet en sij bevonden dat sulcx in eenige saecken, hinder of nadeel heeft gegeven. Dl. 78. 
Soo is in bedencken genomen of al nodigh zij weder een capiteijn der Chinesen aengestelt werde. En 't een tegen 't ander overwogen zijnde goet gevonden hetzelve ten minsten noch voor een jaer tijts aen te sien en uijt te stellen om ondertusschen te ervaren hoe 't sigh best sal willen schicken.

b. Generale missive van Gouv. Gen'. en Raden aan de Verg. van Zeventienen d.d. 25 Januari 1667.

All ettelijcke maenden verleden is hier comen te sterven, de Chinese Capitein Siqua, nae welcke plaets haer diverse sollicitanten hebben opgedaen, maer wij sijn tot noch toe tot geen nieuwe electie getreden, omdat om veele redenen seer is te twijffelen of all nodig sij dat die natie hier een hooft en consequent een stoel in de banck van justitie gegeven werde, meer dan andere, veel stercker sijnde als de Chineesen, behalven de groote snoodheijt van deselve om het recht te verkeren, en de arme luijden daer se over te seggen hebben, uijt te suijpen, waerom wij nae verscheijden deliberatien hebben goetgevonden het aenstellen van een ander capitain noch voor ettelijcke maendet aen te sien, om te ervaren hoe het sich schicken sal.

c. Particuliere missive van G.G. Joan Maetsuijker. (Vgl. bl. 26.)

\section{d' $\mathrm{H}^{\text {re }}$ Pieter van Hoorn}

Mijnheer,

Njaij d'Siko weduwe van den overleden Ziqua, Capiteijn de: Chinesen alhier, heeft in den voorleden jare affgesonden een jonck van 120 lasten, die nevens UE en Comps schepen is vertrocken ${ }^{2}$ naer Hocksieuw ${ }^{3}$ en omtrent het eijlandt lay-sing-soewa bij Canton gebroocken en gebleven sijnde, sijn 41 personen van het meede varens volck geberght en van daer in Hoksieuw overgevoert, daer onder gerekent Gankanio haeren Nachoda en $\mathrm{Ou}$ tsay den schrijver, beide van de negerije tsoewantsoehoe tongangquan ${ }^{4}$ mitsgaders den koopman Tanhin van de negrij tsioe

1 Vgl. Missive Firando (Japan) 14 Oct. 1621: „'t volck aan te halen ende uït te suijpen" en P. A. Leupe: Salomon Sweers, Raad van Indië 164t „geldgierig en bij al de wereld door zijne uitzuiperij gehaat is". Bijdr. Kon. Inst. 3, VIII, bl. 45.

- Zie Dagr. Bat. 1666, bl. 102 en Miss. Reg. Bat. naar Japan dd॰ 9 Mei 1667.

3 Foochow, hoofdstad der provincie Foehkian.

- Prefectuur Tsoan Tsioe, departement Tangoa (Tongaan). 
soehoe, liong-kekoan, ${ }^{1}$ die neffens de resterende 38 persoonen alle op Batavia woonachtigh sijn en bij haer alhier gesonden brieff versocht heeft om van hare detentie gelargeert en met comp schepen overgevoert te worden. Ende want d'E. Comp vreede met die van China heeft en voor onse goede ingesetenen te sorgen staet, soo en konnen wij niet twijffelen of sullen voorsz. persoonen, haer bekendt gemaekt sijnde te wesen onse ingesetenen, loslaten en UE. overgeven, tenminsten als haer gepresenteert wordt te voldoen de verteerde montkosten en ongelden, die dito weduwe belooft aen $\mathrm{d}^{\prime} \mathrm{E}$. Comp ${ }^{\circ}$ te restitueren, derhalve soo UE. de sake bekent ware, en soodanig geconstitueert bevindt dat haer verlossinge versocht wierde sonder schade van d'E. Compe, hebben wij bij desen UE. willen vermanen en recommanderen tot het effect haerder verlossinge te komen.

Onderst. en was geteeckent ende in margine:

UE. dienstb. vrundt

Joan Maetsuijker.

Batavia, 14 Junij, $A^{\circ} 1667$.

\section{Bijlage 3.}

a. Res. 25 October 1740 .

Vervolgens ook gesproken en met eene in aanmerking genomen sijnde hoe in de presente constitutie des tijds dat de Stad en voorsteeden van de Chineese natie is ontbloot geraakt, men wel een à twee Chineesen van een goeden reuk van noden heeft, omme bij provisie te dienen als introducteurs van hare natie, die van de buijtenplaatsen en uijt China alhier mogten aankomen, zo is na overweging van het nodige goedgevonden en verstaan daar toe uijt de Chineese natie als voor goede en deugtsame Chineesen bekend sijnde aantestellen den presenten Cap $^{n}$ der Chineesen op Cheribon met name Oeij Tien Sieuw, en den Chinees handelaar Tan Iko althans ${ }^{2}$ remoreerende op Java's Oostkust ${ }^{3}$ mitsgrs: daarvan kennisse te geven aan de bedientens van Samarang en Cheribon, ten eijnde die twee

\footnotetext{
${ }^{1}$ Prefectuur Tsiang Tsioe, departement Liongkcee.

2 althans $=$ thans.

3 Over de uitdrukking: Java's Oostkust, zie Priangan II, 53(2).
} 
personen op een minsame wijse aantezetten omme sig herwaarts met'erwoon te begeeven tot het waarnemen van voors. hare opgelegde functie, terwijl met eene g'arresteerd wierd deselve met hare komste voor eerst buijten de boom te laten logeeren en huijshouden.

\section{b. Res. 29 November 1740 .}

Ingevolge het aangeschreevene bij aparte letteren ${ }^{1}$ van den 29: 8 ber jongstl. conform het g'arresteerde op den 25 's bevorens, deeser dagen van Samarang herwaarts overgekomen sijnde den tot meede introducteur van Chineese vreemdelingen aangestelden Chinees Tan Iko met nog seeven stux van sijne neven, dient-

1 Deze „aparte letteren” zijn niet in het Afg. Bat. Brieff boek gevonden; wel zijn de antwoorden aangetroffen:

Cheribon den $23^{\text {en }}$ November 1740.

..... vervolgens den alhier terwoon zijnde Sabandhaer Oeij Tiensieuw uijt name Uwer hoog Edele grootagtb. met alle soorte van minnelijke voorslagen zoeken te animeeren zig Bataviawaards te begeeven, omme op sijn komst aldaer in voege $U w$ hoog Edele grootachtb. promesse als introducteur der Chineese vreemdelingen te ageeren, dan hoe voordeelig en met wat se. rieuse verzoeken denzelven hebbe aangesproken, heeft zulx egter afgeslagen en mij verzocht $U w$ hoogEdele groot agtb. voor de genegene gunste dies. weegen aan hem beweesen, vrindelijk te bedanken, voorgeerende zijne op. komst niet dan tot zijne merkelijke schade zoude kunnen strekken, te meer hij de Sabandharije volgens contract gemaekt tusschen de gezamentlijke Princen deses rijx voor den tijd van 15 jaeren heeft gehuurd, waarvan reeds nog maer 6 jaeren verstreeken zijn; ook heeft hij een zuijkermolen staande ende geleegen op Gabang, daar en boven met vrouw en kinderen beladen, en zijn gantsche armoedje onder 't Javaentje uijtgezet, buijten zijne nog alhier hebbende steene wooninge $L^{a}$, omme alle het vorenstaande, neeme de vrijheijd op instantig verzoek van den Sabandhaer voormeld, uijt zijnen name $U w$ hoog Edele groot agtb. te smeeken dat van de opkomst na Batavia mag blijven g'eximeerd en alhier als voren continueeren.

Van Java's Oostkust den $12^{\text {en }} 9$ ber 1740.

Den zergeant van de Pommares en twee mindere militairen hebben alhier op den $4^{\text {en }}$ deser aangebragt $U w$ hoog Edele groot achtbaere gevenereerde aparte missive van den $29^{\text {en }}$ des maands bevorens, na welkers gehonoreerde inhoud de Chinees handelaar Tan Iko tans overvaert met een Inlands vaartuijg ten eijnde als meede Introducteur der Chineese vreemdelingen te $\mathrm{Ba}$ tavia geemployeert te werden, wien daer toe volkomen genegen is, en betuijgt zijn onderdanige dankbaarh ${ }^{t}$ voor deese aan hem betoonde dierbare gunste met beloften zig sodanig te sullen gedraegen dat hij deselve meer en meer mag meriteeren en gaan mede over dies neven Tan Souwko, Souw Tsoensing, Queboeko, Linggangko, Quekoheng, Thantsooko, Ong Theijko en Tsie Ienko. 
wegen althans door de heeren raden Extraod ${ }^{\mathrm{s}}$ Nicolaas Crul en Maurits van Aerden, onder een vrage of die menschen mede niet van briefjes tot harer securiteijt ongerustheid soude dienen voorsien te werden, aan de Vergadering te kenne gegeeven sijnde dat den voorm. Tan Iko, schoon hoe geneegen, egter sijn onvermogen hadde betuijgt en versogt omme van die commissie ontslagen te werden, dewijl hij niet konde leesen of schrijven, mitsgrs. sijnen macker in desen den Sabandhaar tot Cheribon Oeij Tien Sieuw na de informatie die men daarvan bereets ingekreegen heeft ook niet geneegen schijnt te weesen vandaar op te breeken dewijl sulx tot desselvs merkelijke schade soude komen te strecken, so wierd na overweging van het nodige goedgevonden, niet alleen aan de hiervorengem. van Samarang overgekomene agt Chineesen de noodige permissie briefjes tot harer securiteijt te laten afgeven, maar ook meergem. Tan Iko en Oeij Tien Sieuw om g'allegueerde reedenen van die commissie te ontslaan.

Alverder wierd op de gedane nadere vrage van haar $\mathrm{Ed}^{\mathrm{s}}$. waar voorm. overgekomen Chineesen soude werden geplaast omme secuur te kunnen weesen, nadien sig nog tot heden inde prauwen waarmede sij overgekomen zijn, hun verblijf komen te houden, en na het geresolveerde op den $3^{\text {en }}$ deeser binnen de stad niet vermogen te komen, so wierd almeede tendeesen opsigte goedgevonden en verstaan den gem. Chinees Tan Iko met zijn gevolg te plaatsen in het huijs van den omgekomen Chinees Oeij Lianko: staande buijten de boom in het blok daartoe gedespecieert, mitsgad $^{\text {s }}$ den eerstgem. als een groot negotiant sijnde te permitteeren omme bij dag in het Casteel en bij den heer Directeur Generaal te mogen komen omme over den handel en negotie te spreeken, en voorts tot meerder securiteit van voorm. natie die indertijd van buijten mogte aankomen, een aparte magt van Europeesen in dat blok te leggen, teneijnde daardoor deselve van alle overlast te bevrijden en teffens sorge te kunnen dragen van niemand's avonds na half seven uuren in dat blok te laten komen.

Bij eene poging tot diefstal in „de woning van den Chinees Tan Iko, staande en gelegen in de Chineesche kampong buijten deser stadt ${ }_{n}(25$ Aug. 1742), kwam ook ,de daar omtrent posterende Europeese wagt" te hulp. (Crimineele Rol 29 Sept. 1742). 
Bij dese gelegendheit dan ook al met eene gesproken sijnde over de noodsakelijkheid dat instede van de hier vorengem. Chineesen wel andere personen wierden vereijst waaraan sig de anachodas van de verwagt werdende jonken uijt China en de verdere aankomende Chineese handelaars sig souden kunnen en mogen adresseeren om haar versoeken en verdere saken de negotie rakende aan de Heeren den Gouverneur en Directeur Generaal te kunnen voordragen, en waartoe al met eene als een bequaam subject te vorenquamen den Coopman Henry Abbis., die door sijne verscheijde togten van China vermeend wierd de vereischte capaciteit te besitten omme met die natie waaronder hij bekent geworden is te kunnen omgaan, so wierd goedgevonden den voorm. Abbis als Gecommitteerde over de aankomende Chineesen voor deesen jare aan te stellen, mits met den Sabandhar communicatif gaande. (Verg. Brief aan Bewindhebbers dd. 10 Januarij 1741).

\section{c. Henry Abbis.}

Het eerst is hij vermeld gevonden in Res. 8 April 1727: "Is verstaan te accorderen het versoek van den engelsman Hendrik Abbis den $4^{\text {en }}$ deeser met het Portugees schip Nosso Senhora de penha als passagier te deeser plaatse aangekomen van Macao om eenige tijd of tot het vertrek van gemelte bodem alhier te mogen verblijven tot het liquideeren en inmaanen van verscheijde uijtstaande penningen hem van deese en geene competeerende, soo hij voorgeeft, onder recommendatie nogtans om zijne affaires ten eenemaal te vereffenen ten fine onder diergelijke pretext niet weder te komen tot het drijven van negotie op een indirecte wijze ofte op de namen van Chineezen.»

Bij Res. 11 Februari 1735 wordt hij in den dienst der compagnie aangenomen en aangesteld tot koopman en carga in den Chineeschen handel, omdat hij "zig sedert een ruijm getal van jaren met af- en aanvaren na het voormelde rijk [China] heeft besig gehouden» (Vgl. Gen. Missive 31 Maart 1735), en ondanks dat de aanstelling van vreemdelingen bij verscheidene ordres van Heeren XVII was verboden.

Bij Res. 20 April 1736 wordt hij aangèsteld tot "eerste carga». Hij komt echter in verdenking - evenals de supercarga's Pieter Valk en Vincent van Wingerden - omtrent den inkoop van thee niet met. de vereijschte trouw gehandeld te hebben, waarom 
werd besloten hem uit China te laten overkomen (Res. 27 Mei 1737). Hij wist zich echter te verantwoorden (Res. 7 Maart 1738) zoodat hij weder emploijabel werd verklaard (Res. 12 Mei 1738), tevens werd besloten hem in het aanstaande jaar weer als eerste supercarga te emploijeeren, waartoe hij ook bij Res. 21 April 1739 werd aangesteld. Aan het einde van Febr. 1740 kwam hij te Batavia terug (Res. 6 Mei 1740) en bij Res. 8 April 1740 werd besloten dat hij te Batavia zou verblijven.

Uit Res. 2 Dec. 1740 blijkt dat de G.G. de aanstelling van Abbis tot Gecommitteerde voor de Chineezen wel niet approbeerde maar er zich bij heeft neergelegd. Op dien datum wordt in Rade van India voorgesteld: "of het niet dienstig soude wezen dat den jongst aangestelden Commissaris over de Chineese natie den coopman Henry Abbis een woning omtrend de Boom wierd aangeweesen en een instructie tot sijnen narigt geformeert», waarop wordt besloten geen instructie aan Abbis te geven als onnoodig zijnde «dewijl denselven gehouden is van alle voorvallende saken kennisse te geven aan den Heere Gouverneur Generaal, dog denzelven daarenteegens een woning aan het Viercant te besorgen omme altijd bij de hand te weesen tot het hooren en spreeken der Chineese natie.»

Nadat bij Res. 17 Maart 1741 gunstig was beschikt op zijn *versoek omme vermits ruijme tijdsexpiratie met een der retourschepen van de eerste bezending in dit najaar na Nederland te mogen werden verlost, " kwam hij hierop terug en werd hem bij Res. 16 Mei 1741 vergund "alhier te mogen verblijven». Bij Res. 23 Aug. 1743 werd "tot sabandaar en licentmeester aangestelt den buijten emploij sijnden coopman Henry Abbis.» Bij Res. 24 December 1744 werd wegens zijn overlijden een opvolger aangesteld.

In de crimineele Rolle van 1743 (October) wordt gesproken van interrogatoria [ 1 en 2 Oct. 1742] beantwoord door den coopman Henry Abbis "waaruijt middag klaar is komen te blijken dat de heer Mr. Willem Vincent Helvetius, ordinair lid in desen rade en $\mathrm{Mr}$. Cornelis Phillips, gesuspendeert advocaat fiscaal van India, hun ijder in 't bijsonder hebben schuldig gemaakt aan een ongeoorloofde en onmenschelijke massacre van een menigte Chineesen, d' eerste in 't hospitaal van die natie en de laatstgemelde in des E. Comps boeijen en andere plaatsen." (Vgl. Kol. Archief, Koloniale Aanwinsten No. 59). Toen de Raad ordinaris 
Elias de Haeze naar Nederland was gezonden, was Abbis zijn gemachtigde te Batavia (K) A. Stukken proces Valckenier. Aanwinsten $1889 \mathrm{~N}^{\circ} .26 \mathrm{P}$ ).

Henry Abbis was geboren te Londen (Generale Monsterrol van Batavia dd. 30 Juni 1744) en gehuwd met Johanna Sonnemans, met wie hij, ziekelijk zijnde, een testament maakte (16 December 1744, notaris Petrus Dobbelaar. K. A. Testamenten $\mathrm{N}^{\circ}$. 562) waarbij hij legateerde: $2000 \mathrm{rds}$ aan G. G. Van Imhoff, als blijk zijner erkentelijkheid; 1000 rds aan Johanna Magdalena, kind van Pieter d'Espar, over wie hij 2 Juli 1743 ten doop had gestaan (dochter van Pieter d'Espar en Wilhelmina Visser, zie de Haan, Priangan I, 48) en 5000 rds aan zijne zuster Sara, weduwe Cooke te Londen. 